دراسة تتبعيه للتدريب الميدانى بين الواقع والمأمول في ظل الجودة والاعتماد أ. أم / / باريه حسن على حسن ** (1)

يعد المجال التعليمي من أهم الركائز الاساسية لتقدم المجتمعــات ومواجهــة التغيــرات و التحديات الحديثة، حيث إهتمت الدول بالتطوير الحقيقى المنظم في مختلف عناصـر العمليــة التعليمية بما فيها من طرق و أساليب و استر اتيجيات ونظم تدريسية مختلفة بهدف تحقيق الأهداف النربوية و التعليمية النى تصقل مهار ات المعلم الندريسية و النشخصية. ولقد انتشرت في نهاية هذا القرن فكرة البحث عن المعلــم الجيـــ الكــفه، فأعـدت

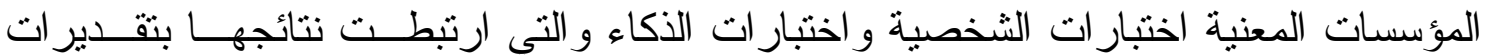
التنريب الميداني علي التدريس وبدرجات اختبار ات نظرية التربية، كما اسـتـعملت الأســاليب الإحصائية المعقدة للكثف عن النتيجة التي تقول أن هؤلاء المعلمين هم اللذين يظهرون مجـالاً

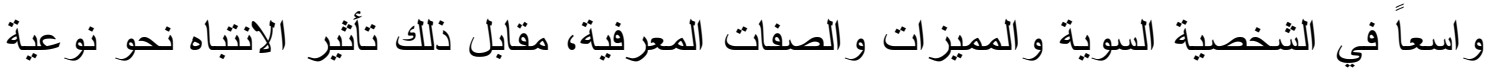

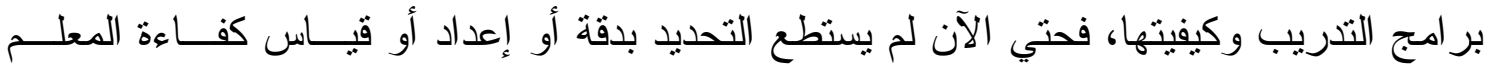

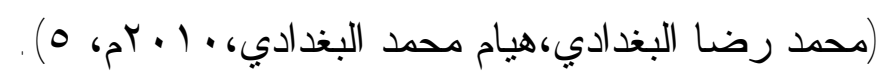

ويحتل التدريب الميداني مكانة متمبزة اذ يطلق عليه الإعداد ما قبل الخدمة فهو بمثــل

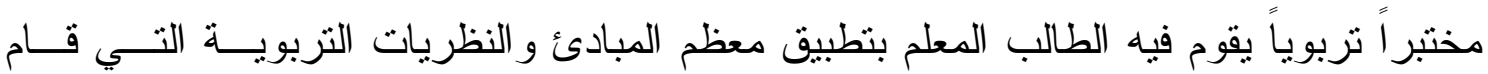

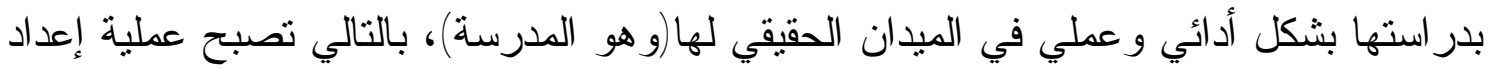

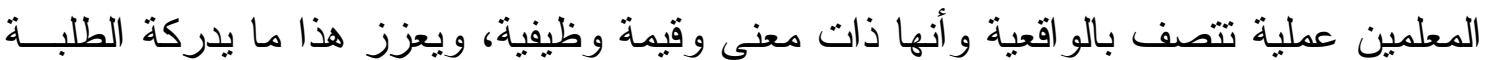

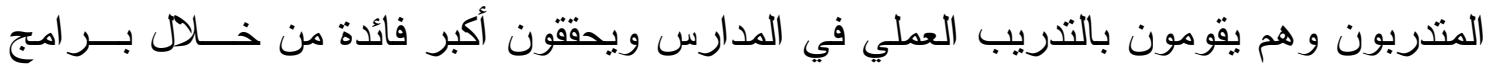

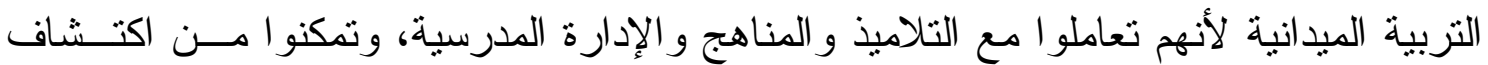

* نسرين مبارك كمال، أستاذ الصولفيج و الإيقاع الحركى و الإرتجال المساعد، قسم التربيـة الموسـيقية، كليــة

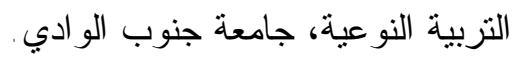
**برية حسن على، استاذ المناهج وطرق تدريس التربية الموسيقية المساعد، قسم التربيــة الموسـيقية، كليــة التربية النوعية، جامعة جنوب الو ادي.

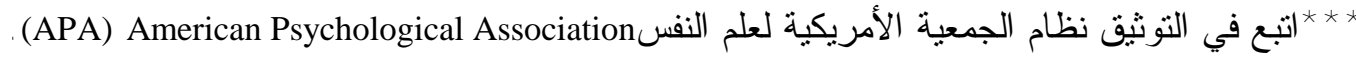


الصعوبات و المشكلات الميدانية بشكل و اقعي كما أنهم حاولو ا تجريب بعض المبادئ و المفــاهيم و النظريات التي درسو ها في كلياتهم حتى يتحقق أعلى قدر من الكفاءة و الجودة.

ولقد ظهرت الكثير من الظواهر السلبية المقلقة، والتي تؤدي الي تدني مستوي التعلــيم

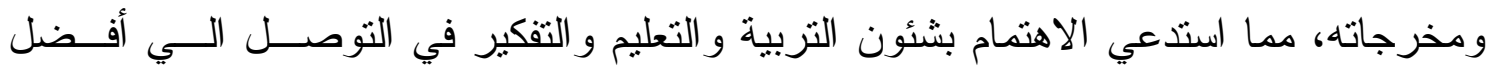

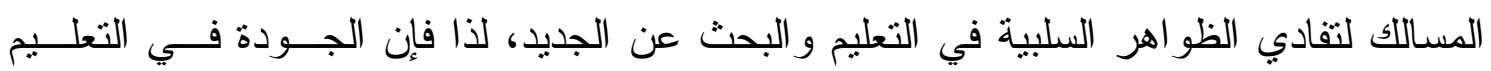

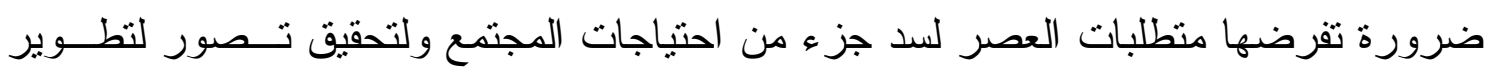
التعليم وتحسينه في مسيرة تحقق الجودة (ابر اهيم بسيوني، و9 99 (م، 70 ).

ويسهم التذريب الميدانى فى تطوير مستوى الطالب المعلم حيث يهــتم بتطــــير النمــو

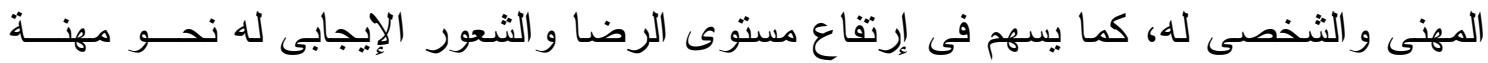

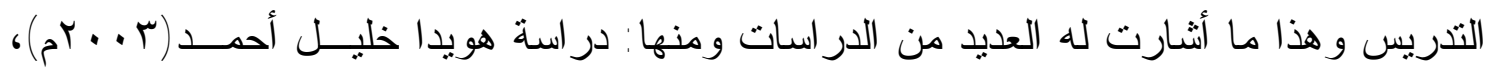

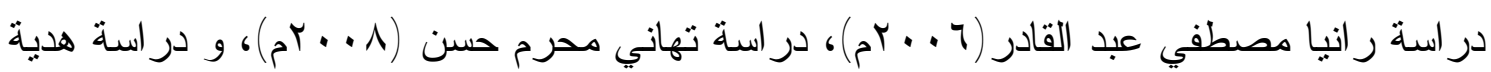

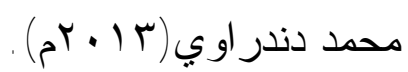

ومن خلال ماسبق يتضح أهمبة تتبع التدريب الميداني لرصد الو اقــع و العـــل علـي

التحديث و التطوير وفقاً لمنطلبات الجودة و الإعتماد .

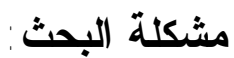

من خلال عمل الباحثتين بمعيار التدريس و التعلم الخاص بالمعايير الأكاديميــة لمركــز

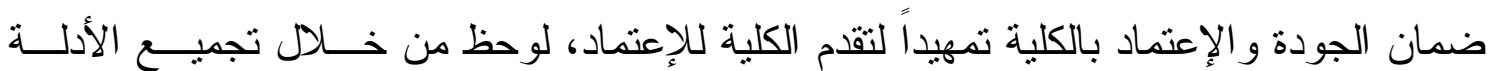

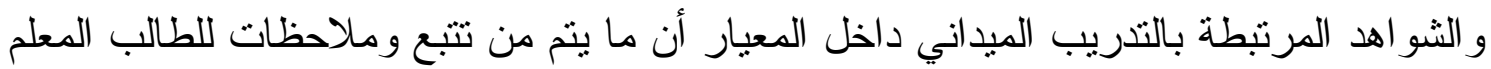
هو اجتهاد خاص بكل مشرف جامعي أو مدرسي أو مدير مدرسة دون الإعتماد علي بنود ثابته

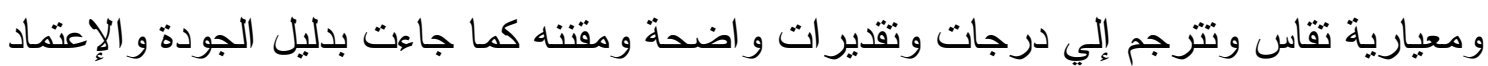

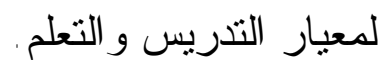

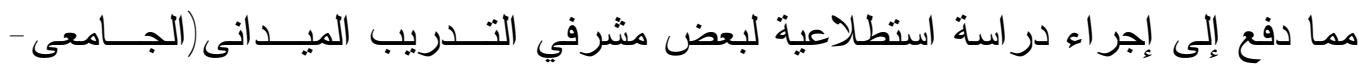
المدرسي) ومدر اء المدارس التى يتم فيها التدريب، حيث جائت نتائج هذه الدراسة كالتالى : 1 - بالنسبة لمديرى المدارس : ينم تقييم الطالب المعلم بنسبة 10 \% على دفتر التحضير

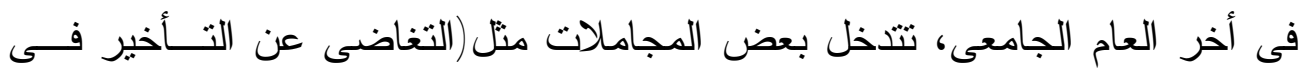


حضور الطالب للمدرسة -السماح للطالب بالتوقيع فى دفتر الحضور بعــــ إنتهــاء

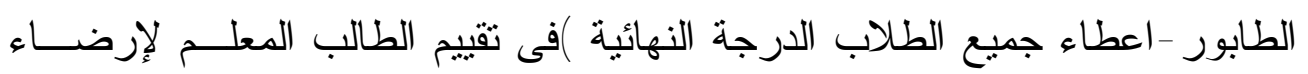

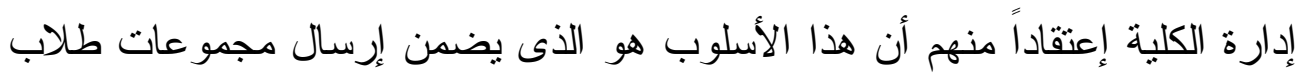

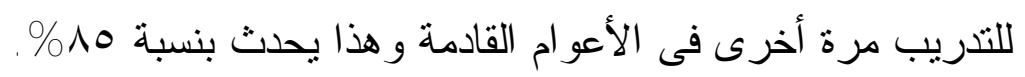

r - بالنسبة للمشرف المدرســي: اتفق أغلب المشرفين على أن العاطفة تتخل فى تقييم

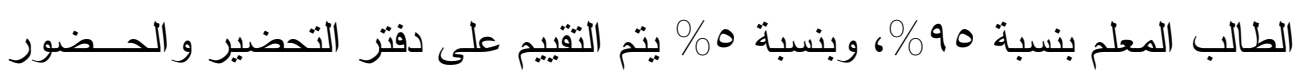
و الغياب وطريقة الثرح داخل الصف الدر اسي ويتم هذا إجتهاداً منهم.

r - بالنسبة للمشرف الجامعى: اختلف كلاً منهم فى اسلوب التقييم ووضـــع الــدرجات

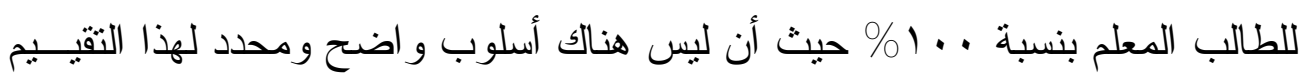
و هو يقوم على الإجتهاد الثخصي لهم لذا قامت الباحثتين بعمل در اسة تتبعيه للحالة الو اقعية للتدريب الميداني مع وضع المأمول تبعاً لمعايير الجودة المطلوبه للإعتماد .

\section{أسئلة البحث:}

1 - ما و اقع مستوي الأداء في التدريب الميداني لطلاب الفرقة الثالثة و الر ابعة شعبة التربية

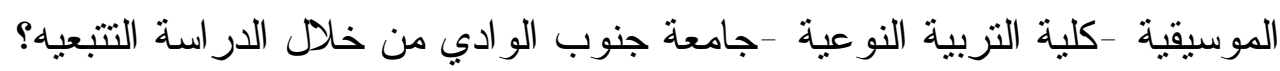
r - كيف يمكن بناء مقاييس لتقييم أداء الطلاب فى الفرقة الثالثة و الرابعة من قبل القــائمين

$$
\begin{aligned}
& \text { بالإشر اف على التدريب الميدانى؟ }
\end{aligned}
$$

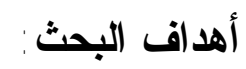

$$
\begin{aligned}
& \text { هدف هذا البحث إلي: }
\end{aligned}
$$

-التعرف على مستوي الأداء الفعلى في التدريب الميدانى لطلاب الفرقة الثالثة و الر ابعة شـعبة

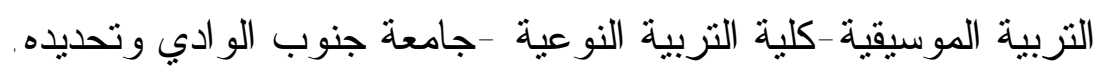
-التعرف أداء القائمين بالاتشر اف علي التدريب الميداني من حيث تقييم وتقــــيم أداء الطــلاب ونز ومنه إلي درجات. -الكثف على(المأمول) لتحسين التدريب الميدانى طبقاً لمتطلبات الجودة في التدريب الميداني.

\section{مجلة علوم وفنون الموسيقى -كلية التربية الموسيقية - المجلد الاثنين والأربعون - بناير •r.r}




\section{أهمبة البحث: 2 - 20}

ترجع أهمية هذا البحث الى

-الإرتقاء بالمستوى المهنى للطالب المعلم مدا ينعكس أثزه على تحقيق النمو الوجدانى والعقلى و الإجتماعى للمتعلمين.

-إمداد إدر اة التوجيه الموسيقي بمقاييس تسهم فى التقييم و القتويم الفعلى للطالب المعلم. -التطبيق الفعلي لمتطلبات معيار التدريس و التعلم وفقاً لمتطلبات الجودة و الاعتماد في التـدريب

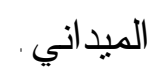

\section{مصطات البحث:}

1 -التدريب الميدانى: يعرف إجر ائياً: بأنه مجموعة من الخبرات و المهار ات التى تقدمها المؤسسات التعليمية للطالب المعلم بحيث تعمل على ربط المعرفة النظرية بالتطبيق العملى بشكل يسهم فى نموه المهنى السليم. r -الجودة والإعتماد: تعرف إجرائياً: بأنها مقار التحسن الذى يطر أ على التعليم بما يتو افق مع المعايير الأكاديمية و المؤسسية ورسالتها بما يودى الى تمكنها من الحصول على صفة التميز بتحقيق هوية معترف بها محلياً ودولياً.

\section{الار اسات السابقة: - ت}

\section{1 -دراسة أميمة عبد الحميد (براهيم ( . . بم):}

هدفت تلاك الدر اسة إلي تحديد الأسس النظرية التي يجب علي الطالب المشرف تعلمهـــا و اقتر اح معايير للتقييم ووضع أسس لتقييم الإختبار النهائي لمادة تقييم التربية الميدانية، واتبعت تللك الدر اسة المنهج الوصفي بدون ذكر العينة، وأسفرت النتائج علي الموافقــة علــي الأسـس المس النظرية الموضوعة.وتتفق نلك الدر اسة مع البحث الحالي في الإهتمام بالتدريب الميداني ووضع أسس يتم من خلالها التقييم، كما تتفق مع البحث الحالي في إتباع المنهج الوصفي، بينما تختلف عن البحث الحالي في اهتمامها بتقييم الطالب المشرف بمرحلة الدر اسات العليا بينما بهنم البحث الحالي بدر اسة و اقع التدريب الميدانى للوصول الى المأمول وفقاً لمتطلبات الجودة و الإعتماد . 
وقد استفاد البحث الحالى من تلك الدر اسة في الإطلاع على الأسلوب الذى يتم به تقيــيم

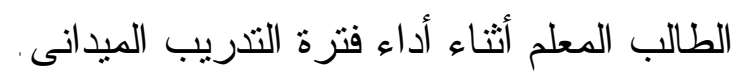

$$
\text { r مدراسة إيهاب لطفي( · r rم): }
$$

هدفت تلك الدر اسة إلي تحسين أداء الطالب المعلم في دروس التنريب الميداني، وقد اتبعت

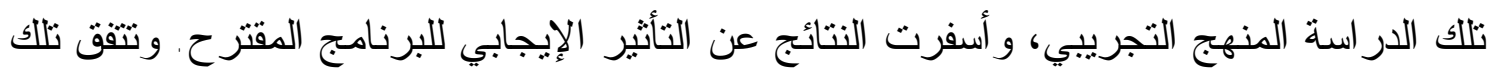

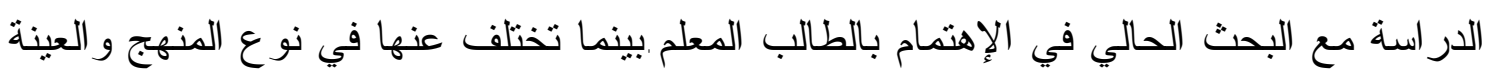

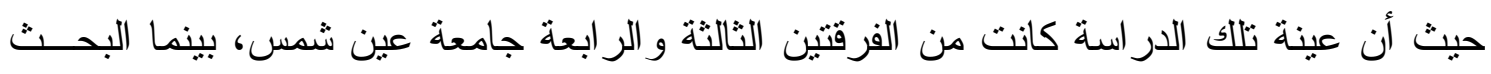

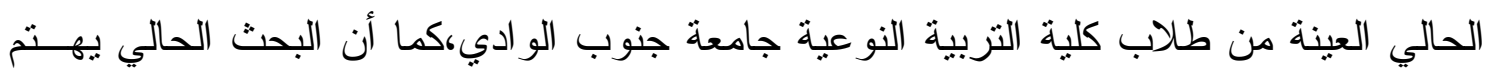

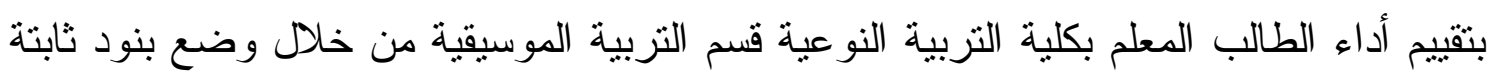

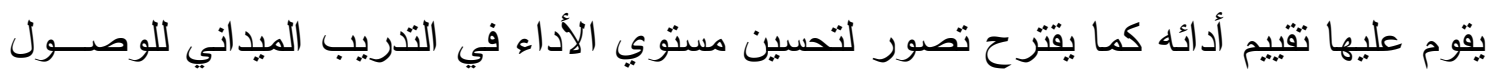
الى أعلى مستوى بالطالب المعلم لتحقيق الجودة و الإعتماد .

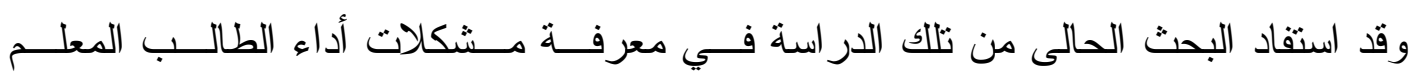

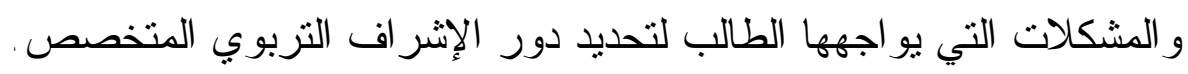

$$
\text { r - دراسة هويدا خليل أحمد (r . . rم): }
$$

هدفت تلاك الدر اسة إلي مساعدة الطلاب علي الابتكار و الإبداع للنشيد و الأغنية المدرسية

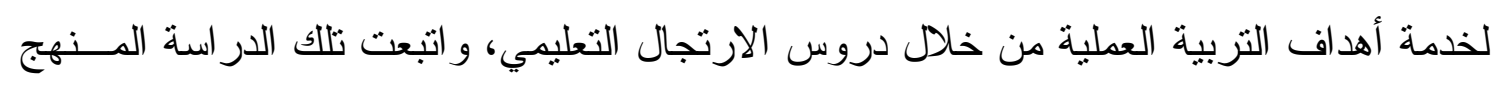

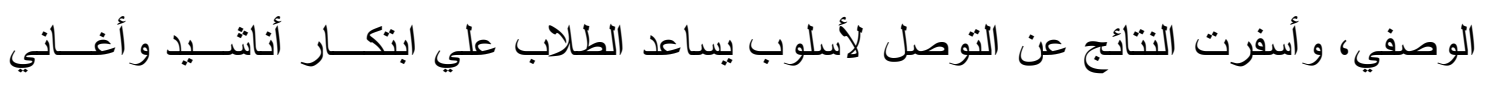
مدرسية ملائمة لمادة التربية الميدانية.

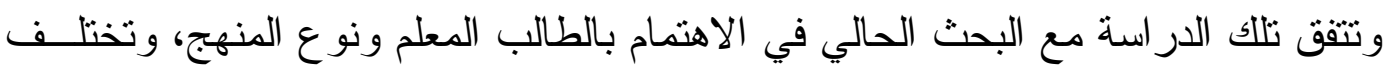

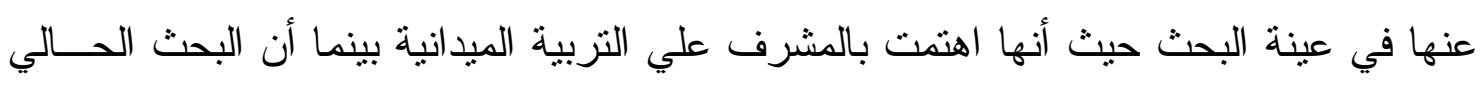

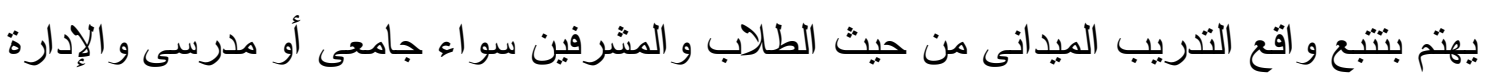

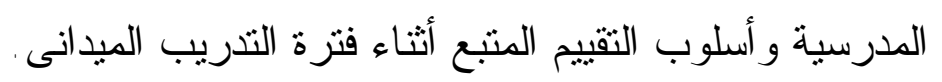

وقد استفاد البحث الحالى من تلك الدر اسة في تحديد أهداف التربية العملية للإستفاده منهــــا.

$$
\text { في توضيح أهداف الإثشر اف علي الطالب المعلم في التنريب الميداني. }
$$

\section{مجلة علوم وفنون الموسيقى -كلية التربية الموسيقية - المجلد الاثنيز والأربعون - يناير •r.r}




$$
\text { ؛ -مراسة رانيا مصطفى عبد القادر(7 . . Y م): }
$$

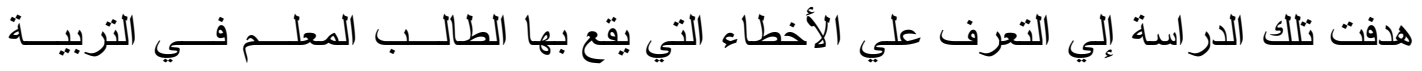

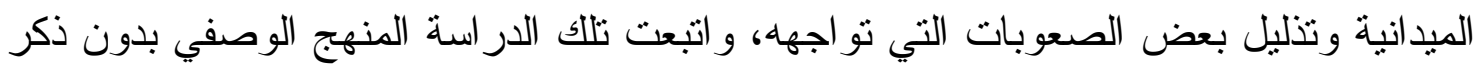

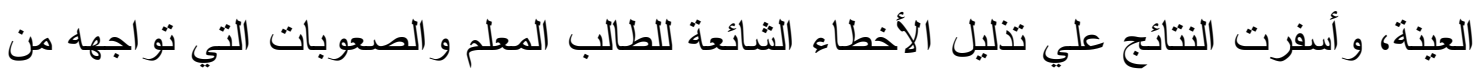

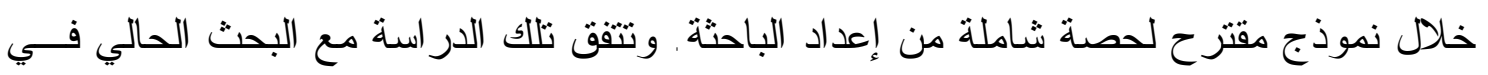

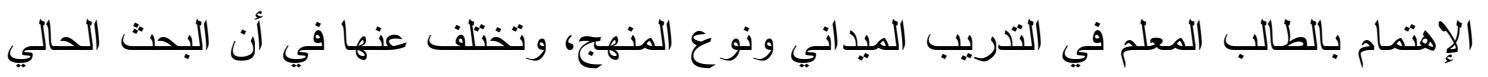

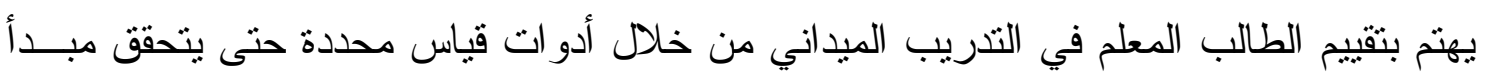
العدالة و المساوة بين الطلاب.

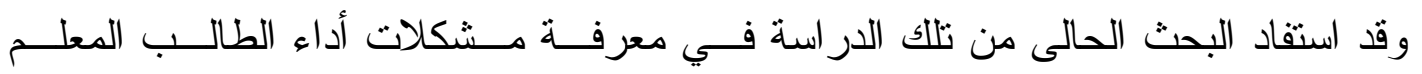
و الصعوبات التي يو اجهها الطالب لتحديد دور الإثر اف التربوي المتخصص.

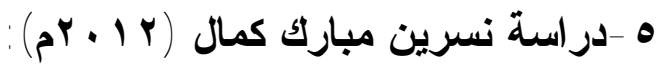

هدفت تلك الدر اسة إلي وضع بنود و أسس واضحة وثابته لتقييم الطالب المعلم بكلية التربية

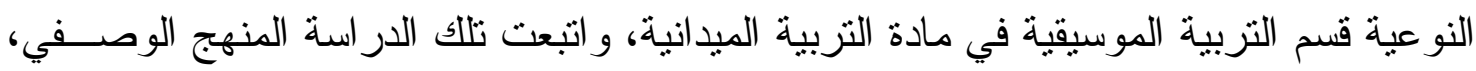

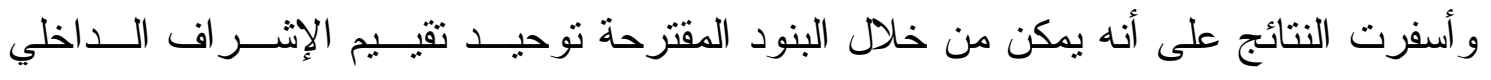

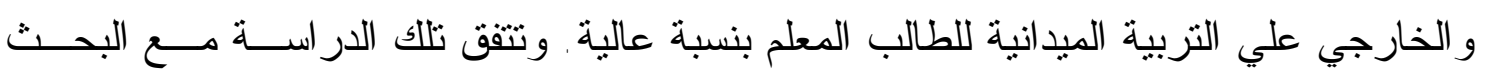

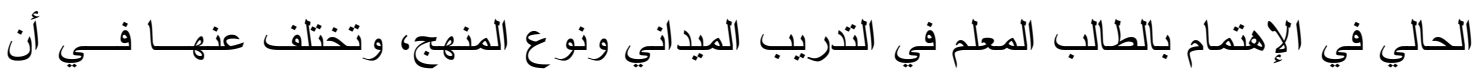

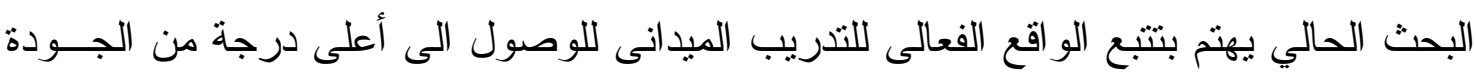
للتقام للإعتماد.

وقد استفاد البحث الحالى من تلك الدر اسة في الإطلاع على الأسلوب المقترح لتقييم الطالب

$$
\text { المعلم أثناء أداء فترة التثريب الميدانى . }
$$

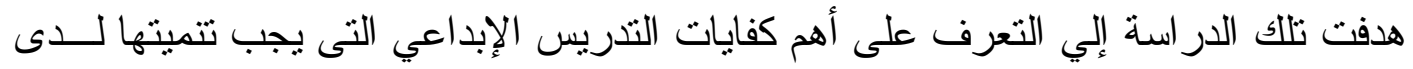

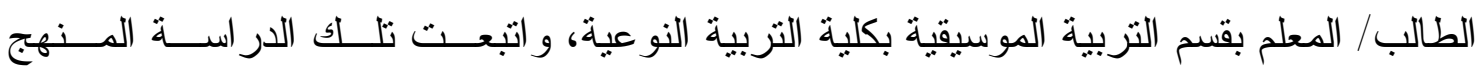

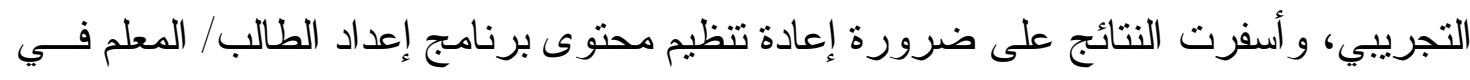

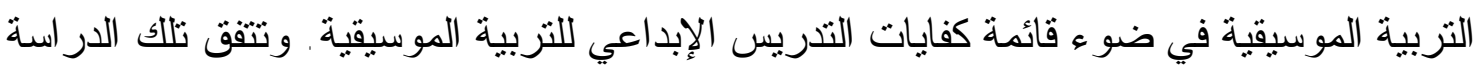




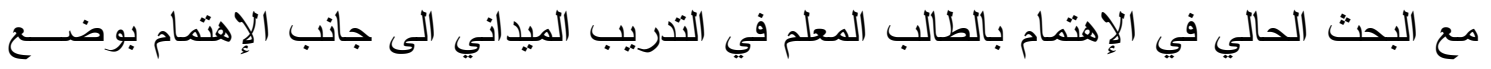

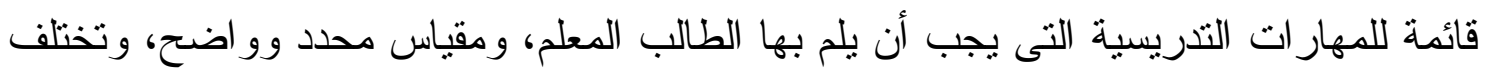

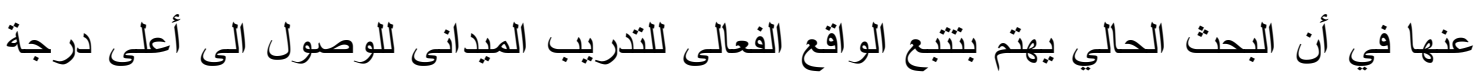
من الجودة للتقام للإعتماد .

وقد استفاد البحث الحالى من تلك الدر اسة في الإطلاع على الأسلوب الدقترح لتقييم الطالب المعلم أثناء أداء فترة النتريب الميدانى. خطــة وإجـــر اعات البحث: منهـجـج البحــث: تم إستخدام المنهج الوصفى لملائكته لطبيعة هذا البحث.

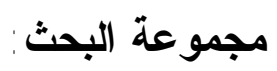

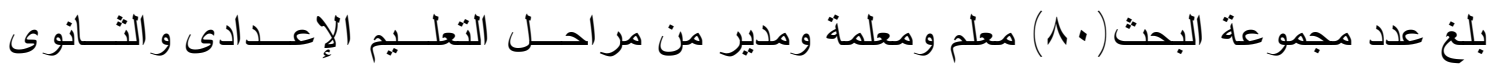

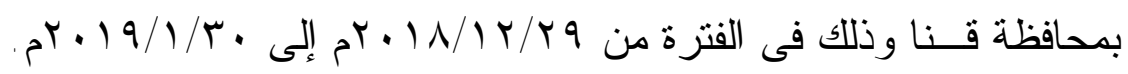

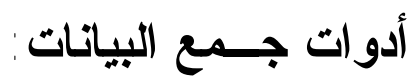

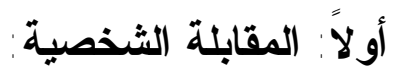

بهدف الحصول على البيـانات و المعلومات من قبل شئون الطلاب ومكتب التّريب الميدانى بكلية التربية النوعية بهدف معرفة عدد الطلاب الذين يأدون التدريب، المشرفيين

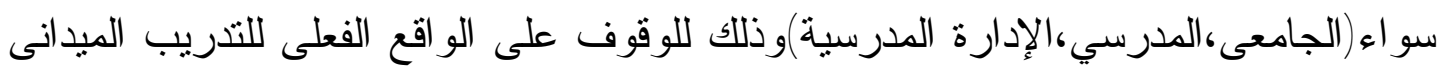
حيث شملت الدقابلة على التالى: 1 - الضو ابط التى يتم من خلالها التدريب الميدانى للطالب المعلم. r - طرق و أساليب التقييم للطالب المعلم .

$$
\text { r - دور كلاً من (المشرف الجامعى،المشرف المدرسي،مدير الددرسة) . }
$$

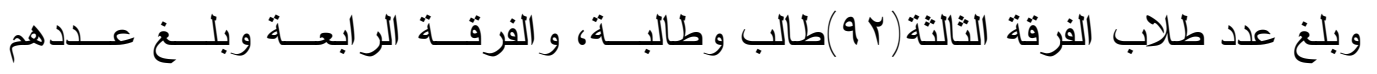
(VA)

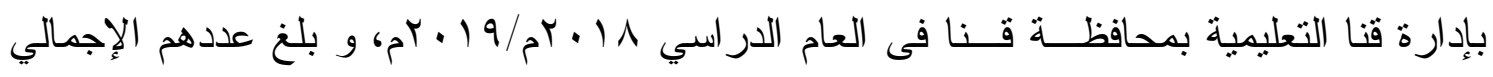




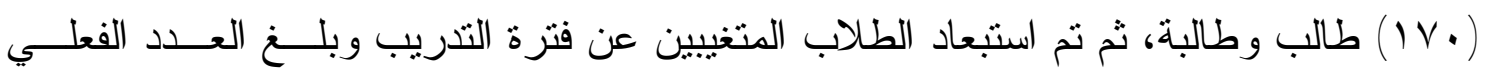
( س ( ) طالب وطالبة وذلك بهدف تتبع الو اقع الفعلى الذى يتم فيه التدريب الميدانى وهم كالتالى:

أولاً الفرقة الثالثةة: - مالثة

\section{جـدول)}

توصيف مجموعة البحث الفرقة الثالثة بمدارس المرحلة الإعدداية بإدارة قنا التعليمية

\begin{tabular}{|c|c|c|c|}
\hline النسبة & فى مجموعة البحث & المجــد الإجمــالي & المدرسة \\
\hline$\% \wedge q, \leq \vee$ & iv & 19 & 1 - جنوب قنا بنات \\
\hline$\% 1 \ldots$ & 19 & 19 & r سبدي عبد الرحيم بنات \\
\hline$\% 1 \ldots$ & 11 & 11 & r -قتا الإعدادية بنات \\
\hline$\% q \leq, \leq \leq$ & iv & 11 & ؛ - الرسمية للغات \\
\hline$\% 1 \ldots$ & 11 & 11 & ه - التحرير الإعدادية بنين \\
\hline$\% q \neg, \vee v$ & $\wedge 9$ & 94 & المجـــوع الكلــي \\
\hline
\end{tabular}

يتضح من الجدول( ()أن العدد الكلي لمدارس المرحلة الإعدادية بمحافظة قتا(ه)مدارس وذللك من خلال الحصر الثامل لأماكن التدريب الميدانى، وبلغت مجموعة البحث الفعلية بعد استبعاد الطلاب المتغييين عن التدريب(19)طالب وطالبة من الفرقة الثالثة

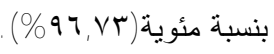

\section{جدول(r)}

مشرفى التدريب الميدانى(الجامعى، المدرسي)للمرحلة الإعدادية بمحافظــة قـــانـا

\begin{tabular}{|c|c|c|c|}
\hline مجموعة البحث & عدد المشرفى المدرسى & عدد المشرفي الجامعي & مدارس المرحلة الإعدادية \\
\hline$\wedge 9$ & 0 & 0 & 0 \\
\hline
\end{tabular}

يتضح من جدول(r)أن عدد المشرفين الجامعيين(0)، و عدد المشرفي المدررسـى(0)،

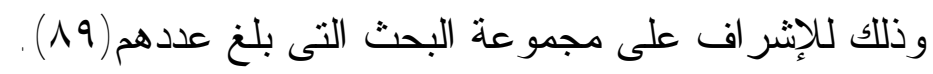


ثانياً الفرقة الرابع: - ت ابع

جـدول)

توصيف مجموعة البحث الفرقة الرابعة بمدارس المرحلة الثانوية بإدارة قنا التعليمية

\begin{tabular}{|c|c|c|c|}
\hline النسبة المئوية & العدد المستخدم فى مجموعة & العجموعة البحثـ & المدرسة \\
\hline$\% 1 \ldots$ & 10 & 10 & 1 - فاطمة الزهراء للبنات \\
\hline$\% 1 \ldots$ & 17 & 17 & r - قنا الثانوية للبنات \\
\hline$\% \wedge \vee, ०$ & $1 \varepsilon$ & 17 & r - السلام الثانوية بنين \\
\hline$\% q 4, r r$ & $1 \leqslant$ & 10 & ؛ - العيدة زينب الثانوية بنات \\
\hline$\%$ \% r, vo & 10 & 17 & ه -السلام الثانوية بنين \\
\hline$\% q \leq, \wedge \vee$ & $V \varepsilon$ & V^ & المجمــوع الكاـــي \\
\hline
\end{tabular}

يتضح من الجدول(r)أن العدد الكلي لمدارس المرحلة الإعدادية بمحافظة قنا(ه)مدارس

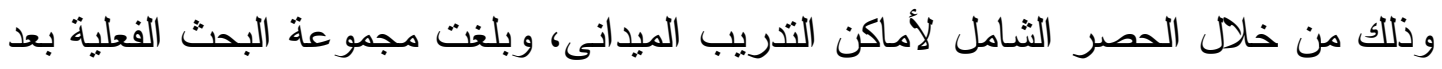
استبعاد الطلاب المتغيبين عن التدريب(1)طالب وطالبة من الفرقة الثالثة بنسبة

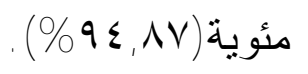

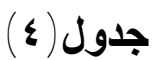

مشرفى التدريب الميدانى ( الجامعى، المدرسي ) للمرحلة الثانوية بمحافظـة قـــا

\begin{tabular}{|c|c|c|c|}
\hline مجموعة البحث & عدد المشرفى المدرسى & عدد المشرفي الجامعي & مدارس المرحلة الثانوية \\
\hline$V \varepsilon$ & 0 & 0 & • \\
\hline
\end{tabular}

يتضح من جدول(ع)أن عدد المشرفين الجامعيين(0)، وعدد المشرفي المدررسـى(0)، وذلك للإشر اف على مجموعة البحث التى بلغ عددهم ع V) . 
قامت الباحثتين بتصميم إستنيان لتحقيق الغرض من إجر اء هذا البحث و المتمنلــة فـى

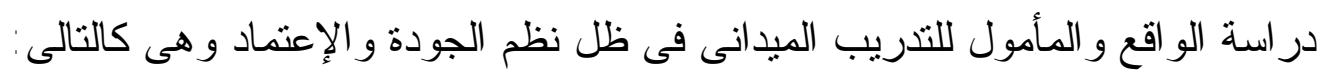

$$
\text { - دور كلاً من المشرف (الجامعى،المدرسى). }
$$

- الإدارة المدرسية للمرحلة الإعداية و المرحلة الثانوية.

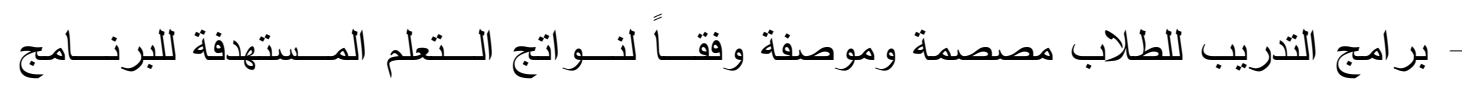
التعليمي،ويتو افر لتتفيذها الآليات و المو ارد اللازمة.

- تقويم أداء الطلاب فى التدريب يتم بأساليب متتوعة وبما يتو افق مع نو اتج التعلم المستهدفة. - فاعلية التشريب تقيم باستخدام أدوات ومؤشرات موضوعية، ونستخدم النتائج فى تطوير آلية

$$
\text { التنريب و أدو اته ومو ارده. }
$$

ولقد اتبعت الباحثثين الخطـــــوات التالية:

1 - تم التو اصل مع مكتب الجودة والإعتماد بالكلية للإطلاع على التوصيف الخاص بالتــدريب

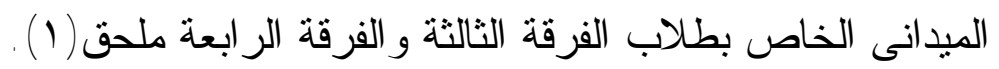

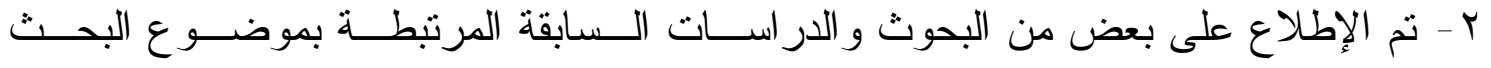

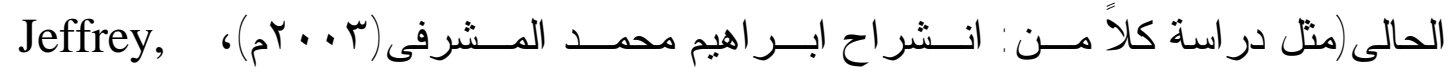

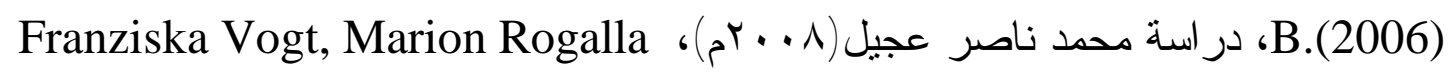

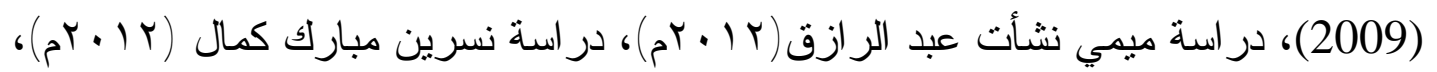
Burnard, Parnela (2012) ، در اسة هدية محمد دندر اوى(r ( • بم)، ودر اسة بدرية حسن

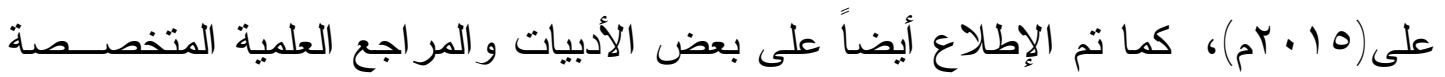

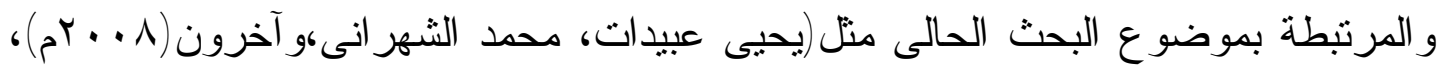

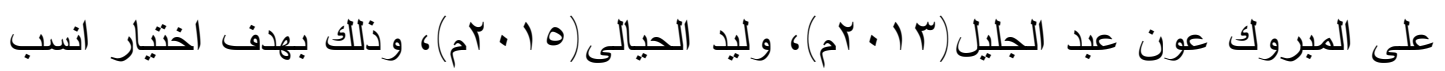

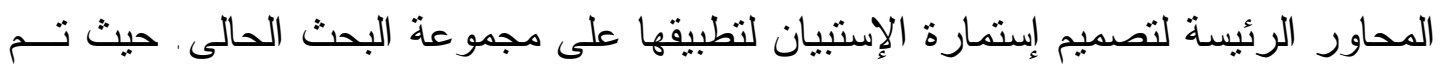

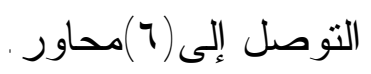


r - نت عرض محاور الإستبيان على مجموعة من الخبراء المتخصصين أساتذة المناهج وطرق

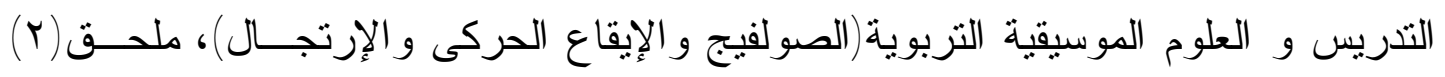
وذللك للحكم على مدى صحة محاور الإستنيان. ـ - نت صياغة مجموعة من العبار ات تحت كل محور من محاور الإستبيان بحيث تعطى فـى

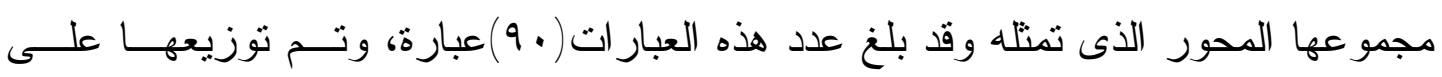
المحاور المختلفة بصورة منظمة حيث بلغت عبار ات كل محور (0 (1) عبارة.

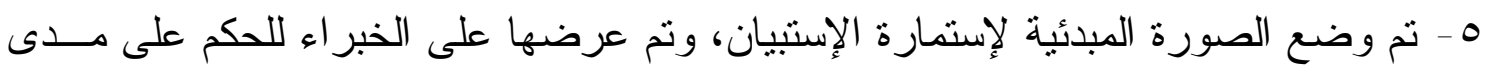

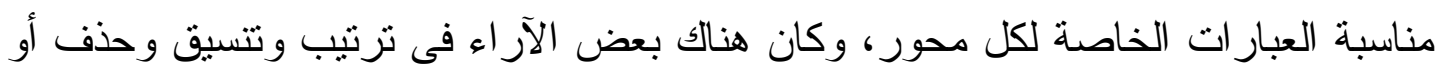
إضافة أو تعديل صياغة بعض من العبار ات .

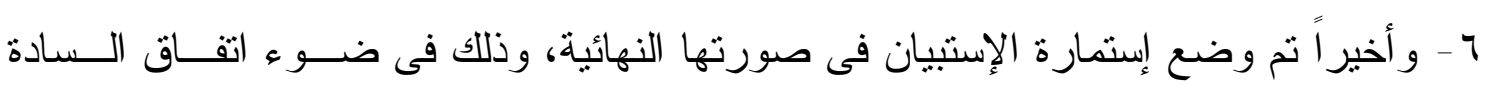

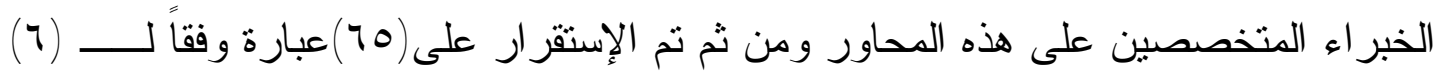
محاور الرئيسه وهى كالتالى:

المحور الأول : قائمة المهار ات التذريسية الخاصة بالطالب المعلم بالفرقة الثالثـــة والفرقـــة الر ابعة( • (1) - مبارة.

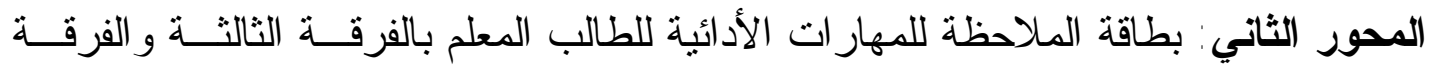

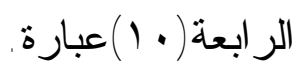

المحور الثالث:الضو ابط الخاصة بالطالب المعلم بالفرقة الثالثة و الفرقة الر ابعة أثنــــاء فتـــرة

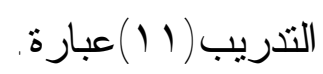

المحور الرابع: دور المشرف الجامعى أثناء فترة التنريب( r ( ) عبارة. المحور الخامس: دور المشرف المدرسي أثناء فترة التدريب(r ( ) عبارة. المحور السادس: دور الإدراة المدرسية أثناء فترة التنريب( • () عبارة. وقد تم استخدم ميزان التقدير الثلاثى: موافـق ويقدر لها(ب) درجات، موافـق إلى حد

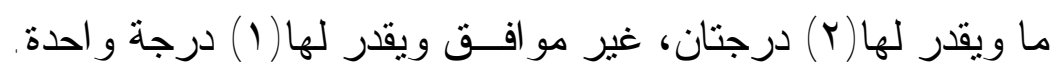

\section{مجلة علوم وفنون الموسيقى -كلية التربية الموسيقية - المجلد الاثنين والأربعون - بناير •r.r}


تم إجر اء در استة إستطلاعية على عينة قو امها (0 1 ) معلم ومعلمــة ومــدير بالمرحلــة الإعدادية و المرحلة الثانوية و (0) أعضاء هيئة التـريس من خارج عينة البحــث ومــن نفس

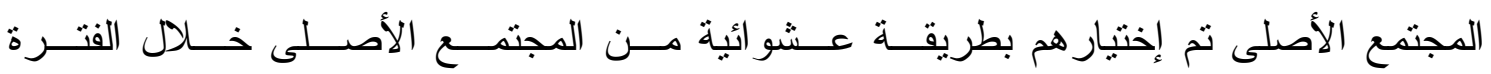

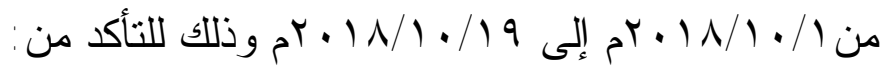

- مدى فهم عبار ات الإستبيان وقد أجمعت الآر اء على وضوح وفهم جميع العبار ات. - إختبار صدق الإستبيان بطريقة صدق المحكمين.

ــ إختبــار ثبــات الإستبيان من خلال التطبيــق و إعــادة التطبيق بفارق زمني( ا ( )يوم بين

التطبيقين .

وقد أسفرت نتائج الدر اسـة الإستطلاعية عن وضوح العبار ات وتفهمها من قبل العينــة.

المعاملات العلمية لإستمارة الإستبيان:

صــدق الاستبيان:

تم إيجاد صــدق الإستبيان عن طريق صدق المحكمين(صدق المحتوي)وذللك بعـرض الإستبيان على بعض الخبر اء من المتخصصين فى مجال المناهج وطــرق تــدريس و العلــوم الموسيقية التربوية(الصولفيج و الإيقاع الحركى و الإرتجال)، وذلك لإبداء الر أبي و الحكــم علـي صحة محاور الإستبيان فيما وضعت من أجله و أيضاً مناسبة العبار ات الخاصة لكل محور وذلك بغرض مقارنة مفردات الإستبيان بالمضمون الذي أعد من أجلة والحكم على مدي تمثيل عبارة كل محور من محاور الإستبيان على المجال الذى يقيسه .

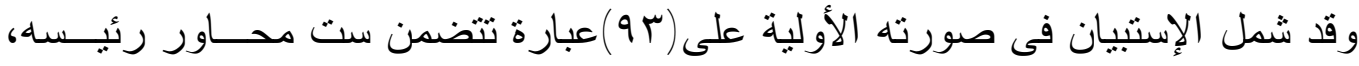

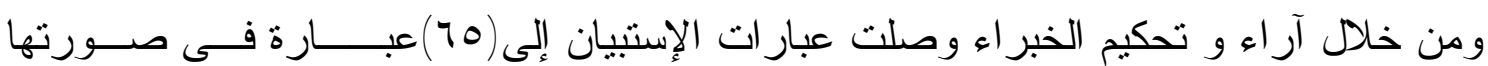
النهائية و الجدول(r) تشير نتائجه إلى تحقيق صدق المحاور التى يتضمنها الإستبيان، كذلك تــم تحديد الأهمية النسبية لكل محور . 


\section{جـدول) (0)}

يوضح محــاور استمارة الإستبيان وعـدد عــبار اتها بعد عرضها على الخبراء

\begin{tabular}{|c|c|c|c|c|}
\hline عــد العبار ات بعد & عـدـد العبارات & عــد العبارات فى & المحـــاور الرئيـــــه & r \\
\hline 1. & 0 & 10 & قائمة المهارات التـريسية الخاصة بالطالب الفرقة & 1 \\
\hline 1. & 0 & 10 & بالطالب المعلم الفرقة الثالثة والفرقة الثراتة الترابعة الخاصة. & r \\
\hline 11 & $\varepsilon$ & 10 & والضرقة الرابعة الخاصة بالطالب المعلم الفرقة الثالثة & $r$ \\
\hline ir & $r$ & 10 & دور المشرف الجامعى أثناء فترة التتريب & $\varepsilon$ \\
\hline ir & $r$ & 10 & دور المشرف المدرسي أثناء فترة التدريب. & ○ \\
\hline 1. & $\bullet$ & 10 & دور الإدراة المدرسية أثناء فترة التدريب & 9 \\
\hline 90 & ro & 9. & المجمـــوع & \\
\hline
\end{tabular}

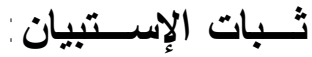

حيث تم تطبيق إستمارة الإسنبيان فى صورتها النهائية المشتملة وذلك عينة قو امها(0)

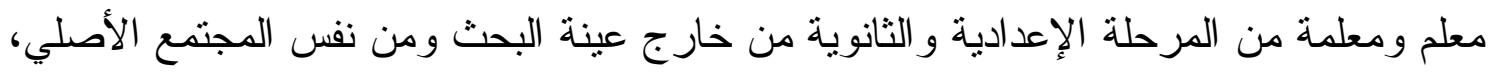

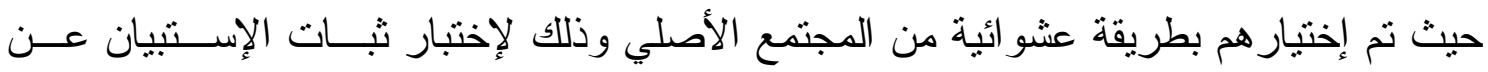
طريق تطبيق الإستنيان و إعادة تطبيقه Test-Retest كما هو موضح بجدول(T). 
جـ (7)

معامـلات الإرتباط بين التطبــق الأول والثانــي لمحسـاور الإستبيان

\begin{tabular}{|c|c|c|}
\hline معامـل الإرتبـــاط " ر" & المحـــــاور الرئيسه & 5 \\
\hline ., vo & قائمة المهارات التصريسية الخاصة بالطالب المعلم الفرقة الثالثة والفرقة الرابعة. & 1 \\
\hline$\cdot, \mathrm{va}$ & بطاقة الملاحظة للمهارات التُريسية الخاصة بالطالب المعلم الفرقة الثالثة والفرقة & r \\
\hline., $\mathrm{v} v$ & الضوابط الخاصة بالطالب المعلم الفرقة الثالثة والفرقة الرابعة أثناء فترة الترريب & r \\
\hline$\cdot, \wedge$. & دور المشرف الجامعى أثناء فترة التتريب. & $\varepsilon$ \\
\hline$\cdot, \mathrm{V} V$ & دور المشرف المدرسي أثناء فترة التذريب. & • \\
\hline ., va & دور الإدراة الددرسية أثناء فترة التدريب. & 1 \\
\hline
\end{tabular}

يتضح من جدول(T)أن قيم معامل الإرتباط دالة أحصائياً عند مستوي(0 . . )مما بـدل

على ثبات المحاور المستخدمة فى إستمارة الإستنيان .

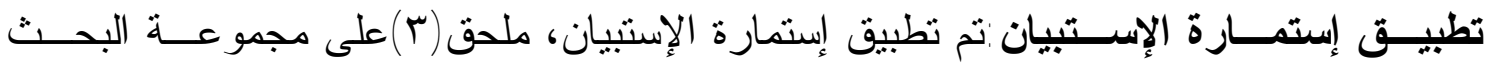

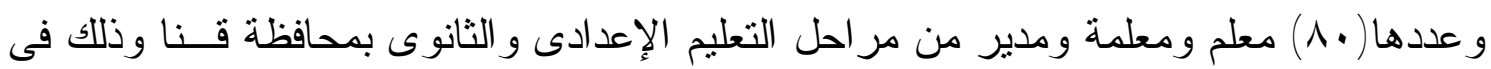

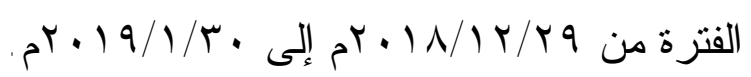
عـرض النتــائج ومناقشتها: أولاً: عــرض النتــائج: تحقيقاً لأهداف البحث و الإجابة عن أسئلته يتم عرض النتـائج علـى

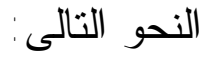




\section{(v) جدول)}

يوضح التكرارات والنسب المئوية وقيمة "كا" ومستوى الدلاية لميزان التقدير الثلاثى لإستبيان المحسـور الأول قائمة المهارات التدريسية الخاصة بالطالب المعلم بالفرقة الثالثة والفرقة

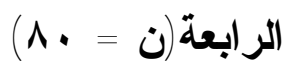

\begin{tabular}{|c|c|c|c|c|c|c|c|c|c|}
\hline \multirow{2}{*}{ مستوى الــدلامة } & \multirow{2}{*}{ قيمــة } & \multicolumn{2}{|c|}{ غير موافــق } & \multicolumn{2}{|c|}{ موافق إلى حـ ما } & \multicolumn{2}{|c|}{ موافِ تـنق } & \multirow{2}{*}{ بالتـريسية الخاصة بالطالب المعلم } & \multirow{2}{*}{ P } \\
\hline & & \% ن & ك & \% ن & ك & ن ن & ك & & \\
\hline$\cdot, \cdot 1$ & $\varepsilon \mid r, r$ & $\% 1 \ldots$ & $\Lambda$. & $\%$. & صفر & $\%$. & صفر & 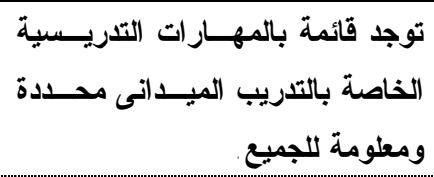 & 1 \\
\hline$\cdot, \cdot 1$ & $\varepsilon \mid r, r$ & $\% 1 \ldots$ & $\Lambda$. & $\%$. & صفر & $\%$. & صفر & 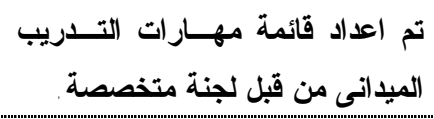 & $r$ \\
\hline غير دال & $\varepsilon$ & $\begin{array}{c}r r, v_{0} \\
\%\end{array}$ & 19 & $\begin{array}{l}r q, r_{0} \\
\%\end{array}$ & YI & $\% 0$. & $\varepsilon$. & 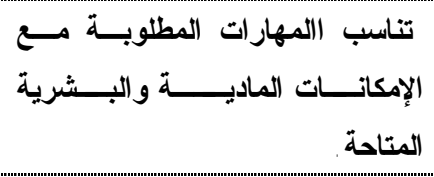 & $r$ \\
\hline$\cdot, \cdot 1$ & $\varepsilon \mid r, r$ & $\% 1 \ldots$ & $\wedge$. & $\%$. & صفر & $\%$. & صفر & 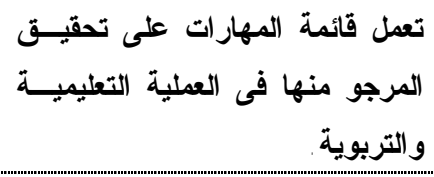 & $\varepsilon$ \\
\hline$\because \cdot 1$ & $\leqslant 1 r, r$ & $\% 1 \ldots$ & $\wedge$. & $\%$ & صفر & $\%$ & صفر & المهارات الموضوعة غير مرنة. & 0 \\
\hline$\cdot, \cdot 1$ & $\varepsilon \mid r, r$ & $\% 1 \ldots$ & $\wedge$. & $\%$. & صفر & $\%$ & صفر & علدم وضوح الهـــ مـن قائمــة & 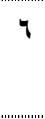 \\
\hline$\cdot, \cdot 1$ & $\varepsilon \mid r, r$ & $\% 1 \ldots$ & $\wedge$. & $\%$. & صفر & $\%$ & صفر & بلأهمية النسبية. غئســر مرتبــة وفقــاً & $v$ \\
\hline$\cdot,+1$ & $\varepsilon \mid r, r$ & $\% 1 \ldots$ & $\wedge$. & $\%$. & صفر & $\%$. & صفر & المهارات غير وات القعية. & $\wedge$ \\
\hline$\cdot,+1$ & $\varepsilon \mid r, r$ & $\% 1 \ldots$ & $\wedge$. & $\%$. & صفر & $\%$ & صفر & فرعية داخل قائمة المهارات. & 9 \\
\hline$\cdot,+1$ & $\varepsilon \mid r, r$ & $\% 1 \ldots$ & $\wedge$. & $\%$. & صفر & $\%$ & صفر & 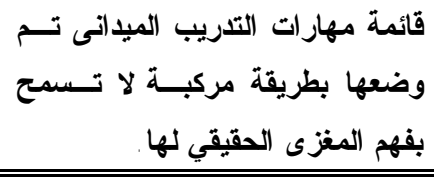 & 1. \\
\hline
\end{tabular}




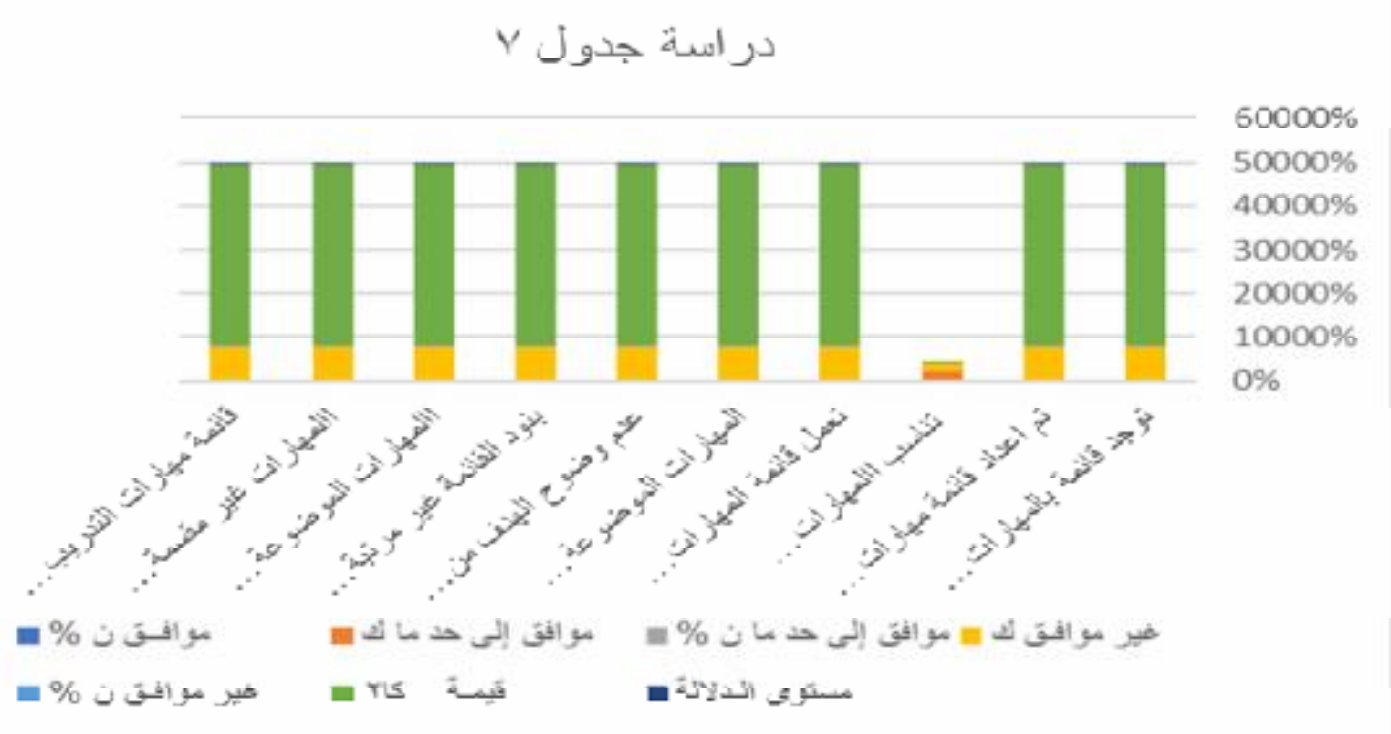

من خلال الجدول السابق يتضح أن قيمة " كاب "عند مستوى دلالة معنوية(0 • , •)ودرجة

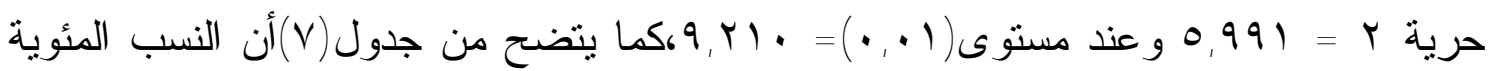
التى تعبر عن استجابات معلمى التزبية الموسيقية والمديرين بالمرحلة الإعدادية و الثانوية على عبار ات الإستبيان الخاصة بقائمة المهار ات التدريسية الخاصة بالطالب المعلم بالفرقة الثالثة و الفرقة الر ابعة البالغ عددها( • ( )عبار ات وذللك بنسب مئوية تراوحت ما بين( . . ( \%)كحد أعلى و ( • \% )كد أدنى للعبار ات، وقد انحصرت إجابات معلمى التربية الموسيقية و المديرين بالمرحلة الإعدادية و الثانوية فى ميز ان التقدير الثلاتى فيما يلى خانة مو افق ما بين(صفر ، ، ع\%)، وخانة

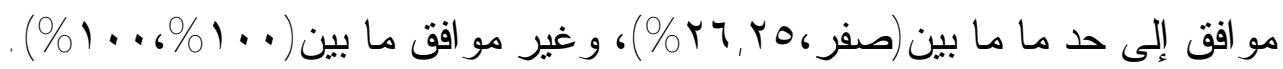




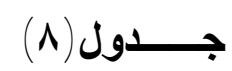

يوضح التكرارات والنسب المئوية وقيمة "كا"" ومستوي الدالاة لليزان التقاير الثلاثي لإستبيان

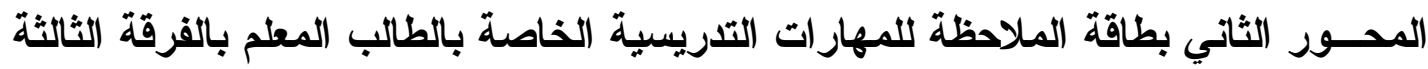

$$
\text { و الفرقة الرابعة الفرية }
$$

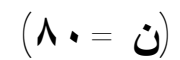

\begin{tabular}{|c|c|c|c|c|c|c|c|c|c|}
\hline \multirow{2}{*}{ مستوى الدلاعـة } & \multirow{2}{*}{ قياك } & \multicolumn{2}{|c|}{ غَيز موافــق } & \multicolumn{2}{|c|}{ موافُق إلى حـ ما } & \multicolumn{2}{|c|}{ مو أفــتُ } & \multirow{2}{*}{ 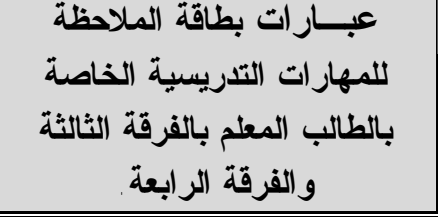 } & \multirow[b]{2}{*}{ r } \\
\hline & & \% ن & ك5 & \% ن & ك5 & \% ن & ك5 & & \\
\hline$\because,+1$ & $\mu, r, r$ & $\% 1 \ldots$ & $\wedge$. & $\%$. & صفر & $\%$. & صفر & 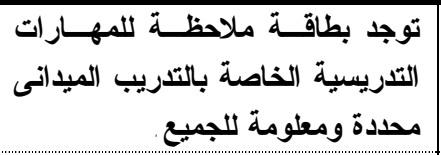 & 1 \\
\hline$\cdot, \cdot 1$ & $r \mid r, r$ & $\% 1 \ldots$ & $\wedge$. & $\%$. & صفر & $\%$. & صفر & 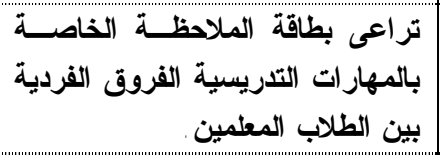 & r \\
\hline$\cdot,+1$ & $r \mid r, r$ & $\% 1 \ldots$ & $\wedge$. & $\%$. & صفر & $\%$. & صفر & 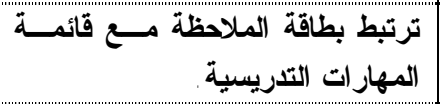 & $r$ \\
\hline$\cdot,+1$ & $\mu, r, r$ & $\% 1 \ldots$ & $\wedge$. & $\%$. & صفر & $\%$. & صفر & 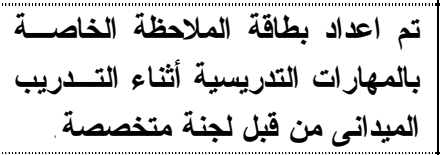 & $\varepsilon$ \\
\hline$\cdot, \cdot 1$ & $r \mid r, r$ & $\% 1 \ldots$ & $\wedge$. & $\%$. & صفر & $\%$. & صفر & 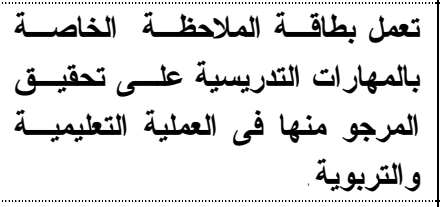 & 0 \\
\hline$\cdot,+1$ & $\mu, r, r$ & $\% 1 \ldots$ & $\wedge$. & $\%$ & صفر & $\%$. & صفر & 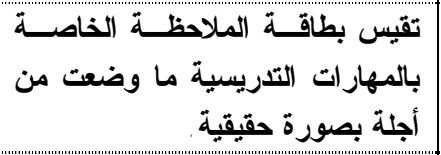 & 7 \\
\hline$\cdot, 1$ & $r \mid r, r$ & $\% 1 \ldots$ & $\wedge$. & $\%$. & صفر & $\%$. & صفر & 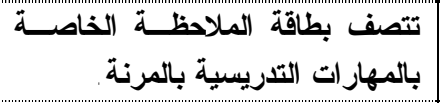 & $\checkmark$ \\
\hline$\because+1$ & $r \mid r, r$ & $\% 1 \ldots$ & $\wedge$. & $\%$ & صفر & $\%$. & صفر & 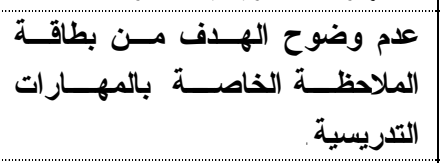 & $\wedge$ \\
\hline$\cdot+1$ & $r \mid r, r$ & $\% 1 \ldots$ & $\wedge$. & $\%$. & صفز & $\%$. & صفر & وفقواً بلأهمية النسبية. & 9 \\
\hline$\cdot,+1$ & $\mu, r, r$ & $\% 1 \ldots$ & $\wedge$. & $\%$ & صفر & $\%$. & صفر & مركبة. & 1. \\
\hline
\end{tabular}

مجلة علوم وفنون الموسيقى - كلية التربية الموسيقية - المجلا الاثنين والأربعون - يناير •r.r. 


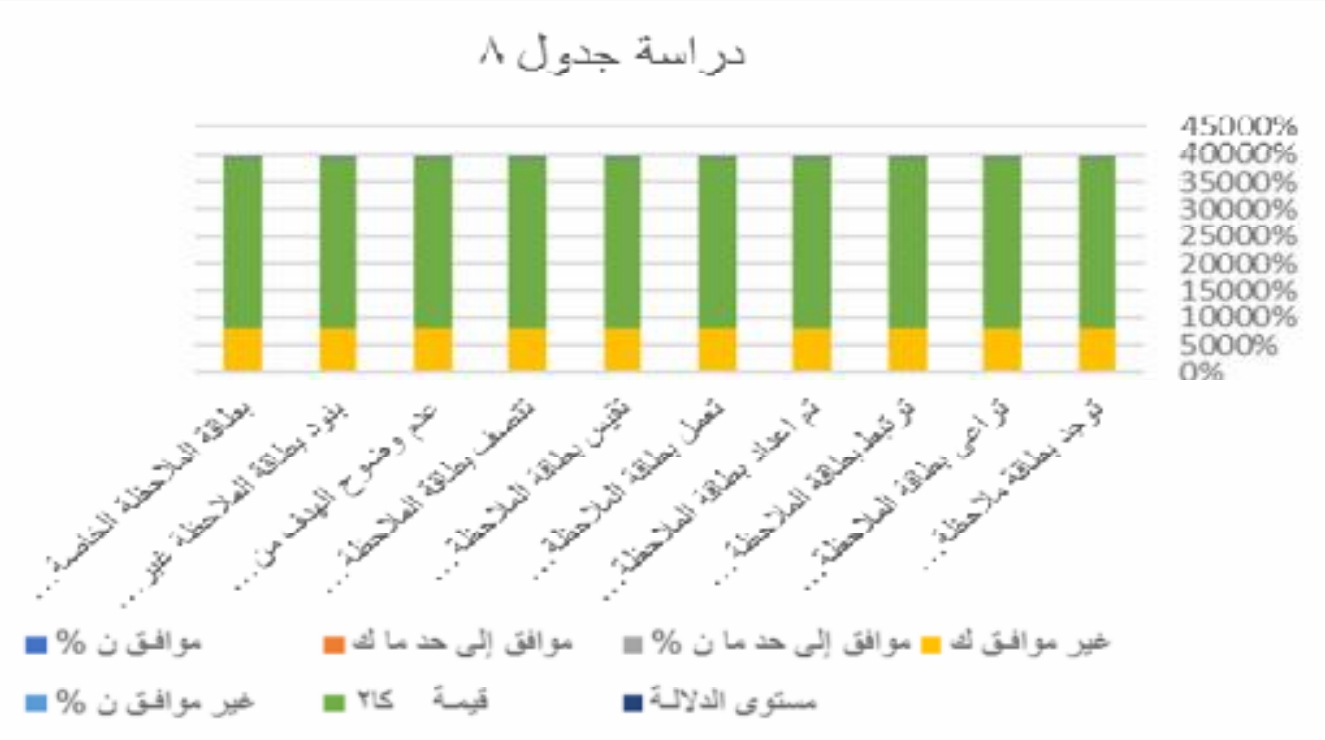

من خلال الجدول السابق يتضح أن قيمة" كا` "عند مستوى دلالة معنوية (0. • •)ودرجة

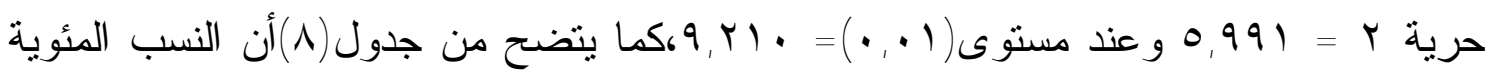
التى تعبر عن استجابات معلمى التزبية الموسيقية و المديرين بالمرحلة الإعدادية و الثانوية على عبار ات الإستبيان الخاصة بقائمة المهار ات التدريسية الخاصة بالطالب المعلم بالفرقة الثالثة و الفرقة الر ابعة البالغ عددها( • ( )عبار ات وذللك بنسب مئوية نز اوحت ما بين(صفر \%)كحد أعلى و ( . ( \%) وحد أدنى للعبار ات، وقد انحصرت معلمى التربية الموسيقية والمديرين بالمرحلة الإعدادية و الثانوية فى ميزان التقدير الثالثى فيما يلى خانة مو افق ما عند(صفر \%)، وخانة

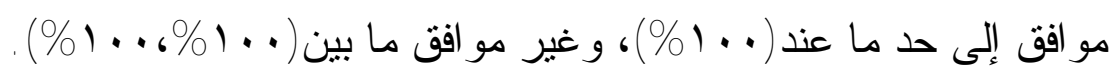


(9) جـدول)

يوضح التكرارات والنسب المئوية وقيمة "كا"ا" ومستوي الدلالة لميزان التقدير الثلاثي لإستبيان المحسور الثالث الضوابط الخاصة بالطالب المعلم بالفرقة الثالثة والفرقة الرابعة أثناء فترة التدريب

$(\Lambda \cdot=\dot{0})$

\begin{tabular}{|c|c|c|c|c|c|c|c|c|c|}
\hline \multirow{2}{*}{ مستو } & \multirow[b]{2}{*}{ 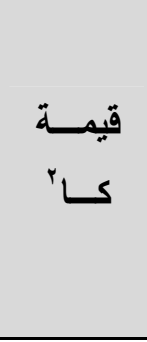 } & \multicolumn{2}{|c|}{ غُبر موافُق } & \multicolumn{2}{|c|}{ هوافُ إلى هـ ما } & \multicolumn{2}{|c|}{ موافــق } & \multirow{2}{*}{ 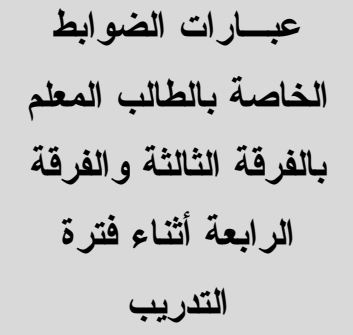 } & \multirow[b]{2}{*}{ r } \\
\hline & & \% ن & ك & \% ن & ك & ن ن & ك & & \\
\hline$\cdot, \cdot 1$ & $111, v r$ & $\% \vee 0$ & 7. & $\%$ ro & $r \cdot$ & $\%$. & صفر & 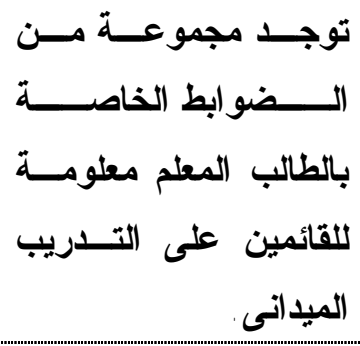 & 1 \\
\hline$\cdot,+1$ & $r 1,9 r$ & صفر \% & صفر & $\% r v, 0$ & Yr & $\% \vee r, 0$. & $\Delta \wedge$ & 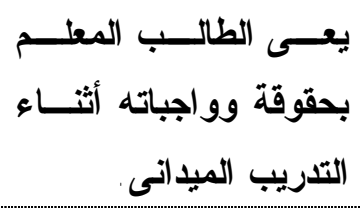 & r \\
\hline$\cdot,+1$ & $10,0 r$ & صفر \% & صفر & $\% \varepsilon$. & rr & $\% 7$. & $\varepsilon \wedge$ & 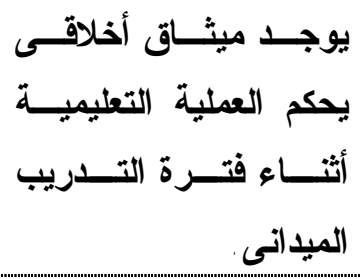 & r \\
\hline$\cdot,+1$ & $r \leq q, \wedge q$ & $\% \wedge 1, r \diamond$ & 70 & $\% \backslash r, v 0$ & 11 & $\%$ & $\varepsilon$ & 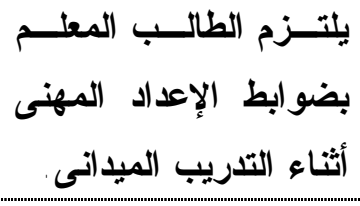 & \\
\hline$\cdot,+1$ & $1 \ldots, v v$ & $\% \circ r, v \circ$ & $\varepsilon r$ & $\% \varepsilon$. & Tr & $\%\urcorner, r \diamond$ & 0 & 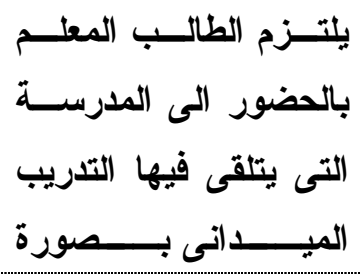 & \\
\hline
\end{tabular}

مجلة علوم وفنون الموسيقى - كلية التربية الموسيقية - المجلل الاثنين والأربعون - يناير .r.r.

$(\mid Y M I)$ 


\begin{tabular}{|c|c|c|c|c|c|c|c|c|c|}
\hline \multirow{2}{*}{ مستو } & \multirow[b]{2}{*}{ قيـــــــة } & \multicolumn{2}{|c|}{ غضير موافق } & \multicolumn{2}{|c|}{ مواقُق إلى حـ ما } & \multicolumn{2}{|c|}{ مو افْتِق } & \multirow{2}{*}{ 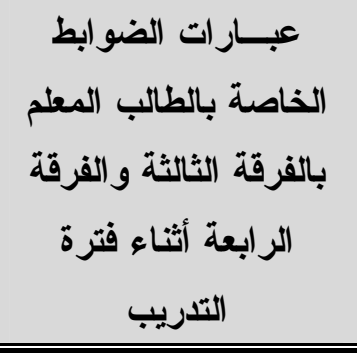 } & \multirow[b]{2}{*}{ r } \\
\hline & & \% ن & ك & ن ن & ك & ن ن & ك & & \\
\hline & & & & & & & & منتظمة. & \\
\hline$\cdot, \cdot 1$ & $r \wedge q, 1$ & $\% \wedge \neg$, Y & 79 & $\% \backslash 1, r 0$ & 9 & $\%$ r. 0 & $r$ & 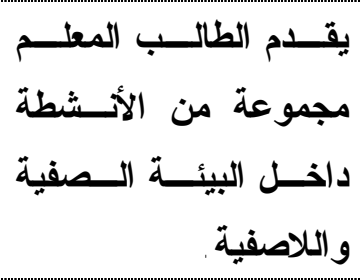 & 7 \\
\hline$\because,+1$ & $\varepsilon \varepsilon, r_{0}$ & $\%$ TV, o & $0 \leq$ & $\% r q, r 0$ & $Y_{1}$ & $\% \curlyvee, r^{\circ}$ & 0 & 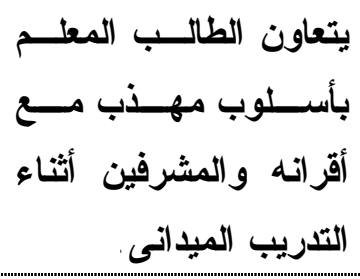 & V \\
\hline$\cdot,+1$ & 09,74 & $\% \backslash r, 0$ & 1. & $\% \vee r, \vee 0$ & 09 & $\%$ Ir,vo & 11 & 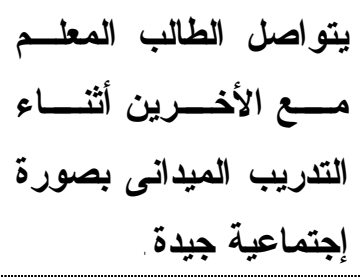 & $\wedge$ \\
\hline$\cdot, \cdot 1$ & 10,01 & $\%$ TV,o & $0 \leq$ & $\% \wedge, \vee \diamond$ & v & $\%$ rr, vo & 19 & 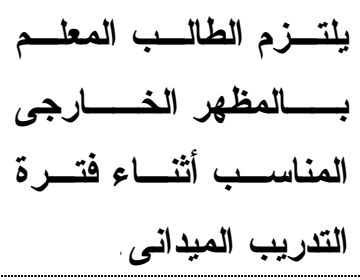 & 9 \\
\hline$\cdot, \cdot 1$ & $I r V, V r$ & $\% \curlyvee \wedge, \vee 0$ & 00 & $\%$ ro & $r \cdot$ & $\% \curlyvee$, Y & 0 & 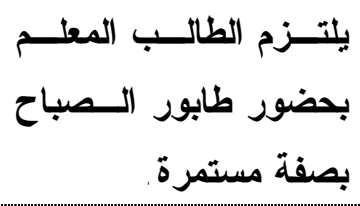 & 1. \\
\hline$\cdot, \cdot 1$ & $r r 1,1 r$ & $\% q \cdot$, & Vr & $\% 1$. & $\wedge$ & $\%$. & صفر & 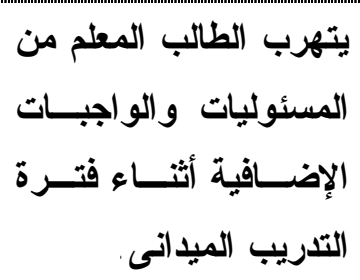 & 11 \\
\hline
\end{tabular}

مجلة علوم وفنون الموسيقى - ملية التربية الموسيقية - المجلد الاثنيز والأربعون - يناير •r.r 


\section{دراسة جدول 9}

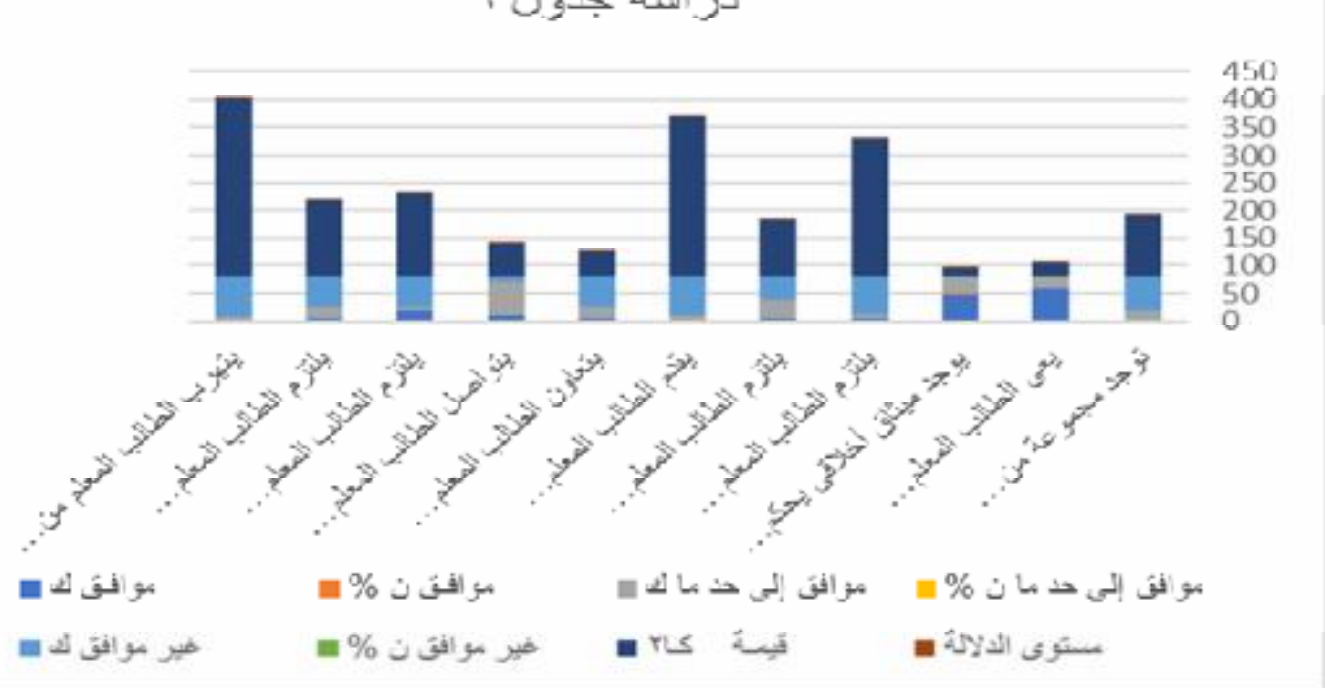

من خلال الجدول السابق يتضح أن قيمة" كا؟ "عند مستوى دلالة معنوية(ه . • )ودرجة

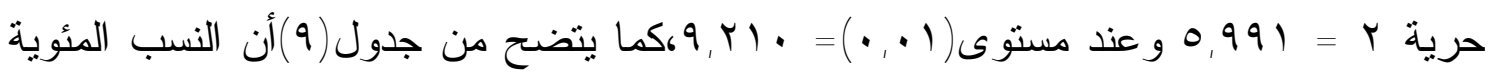
التى تعبر عن استجابات معلمى التزبية الموسيقية والمديرين بالمرحلة الإعدادية و الثانوية على عبار ات الإستبيان الخاصة بقائمة المهار ات التدريسية الخاصة بالطالب المعلم بالفرقة الثالثة و الفرقة الر ابعة البالغ عددها ( ( ) عبار ات وذلك بنسب مئوية نز اوحت ما بين( • , 9 \% )كحد أعلى و (صفر \%)كد أدنى للعبار ات، وقد انحصرت اجابات معلمى التربية الموسيقية و المديرين بالمرحلة الإعدادية والثانوية فى ميز ان التقدير الثلاتى فيما يلى خانة موافق ما ماتى

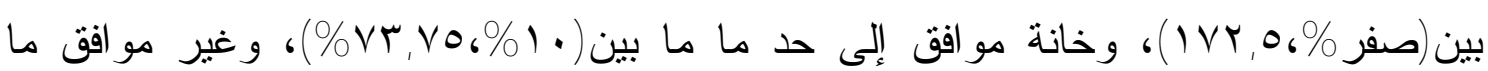
بين (صفر \% \% 9\%\%). 


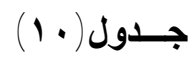

يوضح التكرارات والنسب المئوية وقيمة "كا"ا" ومستوي الدالأة لميزان التقدير الثالثي لإستبيان المحسور الرابع دور المشرف الجامعى أثناء فترة التدريب(ن = . ^)

\begin{tabular}{|c|c|c|c|c|c|c|c|c|c|}
\hline \multirow{2}{*}{ مستوى الدلاة } & \multirow{2}{*}{ قيمـانـاة } & \multicolumn{2}{|c|}{ غير موافـق } & \multicolumn{2}{|c|}{ موافق إلى حد ما } & \multicolumn{2}{|c|}{ مو أفـق } & \multirow{2}{*}{ 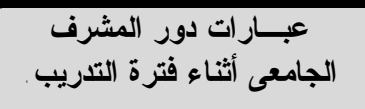 } & \multirow{2}{*}{ r } \\
\hline & & \% ن & ك5 & $\% \dot{0}$ & ك & $\% \dot{ن}$ & ك5 & & \\
\hline .1 & $r \wedge, 1$ & صفر \% & صفر & $\% r r, 0$ & 11 & $\% \vee \vee, ०$. & $9 r$ & تجاه الطاب المشرف المعلم أثناء فتـى بمهامهة & 1 \\
\hline .1 & $r q, \circ v$ & $\% \wedge, \vee \bullet$ & V & $\%$ Y r, & 0. & $\% \curlyvee \wedge, \vee 0$ & $r r$ & فترة المعلم بصورة المشرف الجامعى الطالب & $r$ \\
\hline$\cdot 1$ & $\varepsilon \varepsilon, 07$ & $\% \backslash 1, r o$ & 9 & $\% \curlyvee \wedge, \vee \bullet$ & 00 & $\% r$. & 17 & 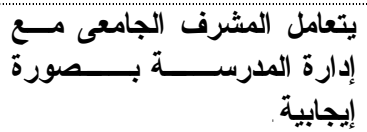 & 'r"' \\
\hline .1 & $r \varepsilon, \varepsilon q$ & $\% r q, r o$ & Y & $\% \bullet \vee, \bullet$ & $\varepsilon 7$ & $\% 17, r \circ$ & 14 & 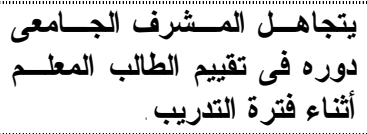 & $\varepsilon$ \\
\hline .1 & $\bullet \wedge, \nvdash \wedge$ & \%rr,vo & $r V$ & $\% \circ \wedge, \vee \bullet$ & $\varepsilon V$ & $\% \vee, 0$ & 7 & 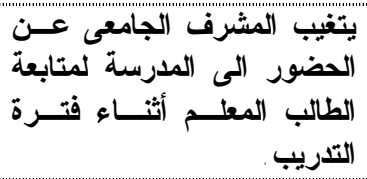 & 0 \\
\hline$\because \cdot 1$ & $r q, 90$ & \%r. & $r \leq$ & $\% 0$. & $\varepsilon$. & $\% r$. & 17 & 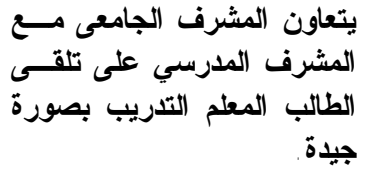 & 7 \\
\hline., 1 & $r 0,1 r$ & $\%$ \% , ২० & $r$ & $\% \leq \wedge, \vee \bullet$ & rq & $\% r r, 0$ & 11 & 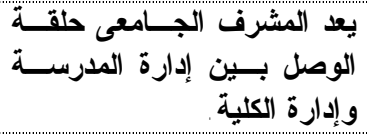 & v \\
\hline$\cdot, 1$ & $q \mu, r$ & $\% \leq V, 0$ & $\mu \wedge$ & $\% 01, r 0$ & $\varepsilon 1$ & $\% 1$, ro & 1 & 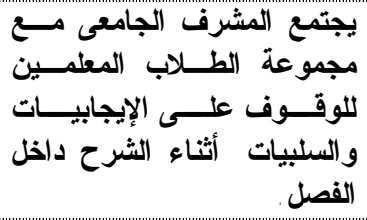 & $\wedge$ \\
\hline$\cdot 1 \cdot 1$ & $1 \cdot \varepsilon, v$. & $\% \circ 1, r o$ & $\varepsilon 1$ & $\% \leq r, v 0$ & ro & $\%$ & $\varepsilon$ & 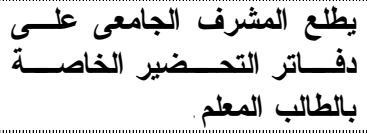 & 9 \\
\hline$\cdot, 1$ & $10 V, r$. & $\% 70$ & or & $\%$ ro & $r \wedge$ & صفر \% & صفز & 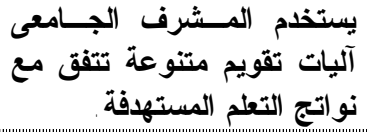 & 1. \\
\hline$\cdot, 1$ & $1 \wedge 9,01$ & $\% \vee i$, ro & $O V$ & $\% r \wedge, \vee \circ$ & $r r$ & صفر \% & صفز & 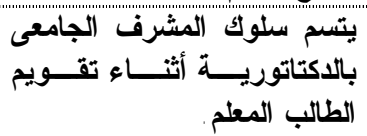 & 11 \\
\hline., 1 & $|r r| r$, & $\% \circ 7, r \circ$ & $\leqslant 0$ & $\% \leq r, v 0$ & ט p & صفر \% & صفز & 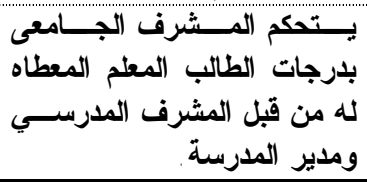 & ir \\
\hline
\end{tabular}

\section{مجلة علوم وفنون الموسيقى -كلية التربية الموسيقية - المجلد الاثنين والأربعون - يناير •r.r.}




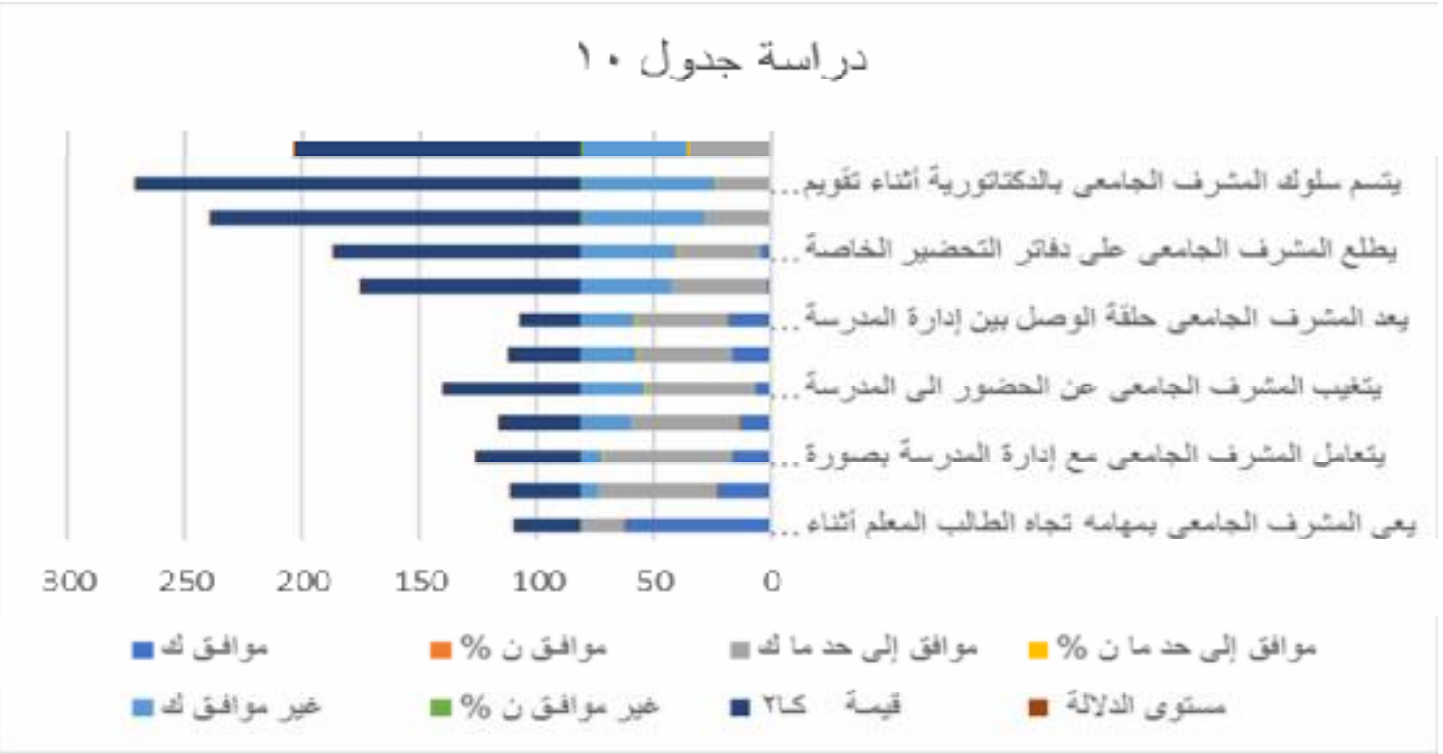

من خلال الجدول السابق يتضح أن قيمة" كا؟ "عند مستوى دلالة معنوية(0. . • )ودرجة

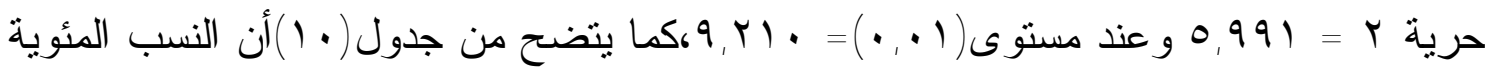
التى تعبر عن استجابات معلىى التربية الموسيقية و المديرين بالمرحلة الإعدادية و الثانوية على الثى عبارات الإسنبيان الخاصة بقائمة المهارات التدريسية الخاصة بالطالب المعلم بالفرقة الثالثة

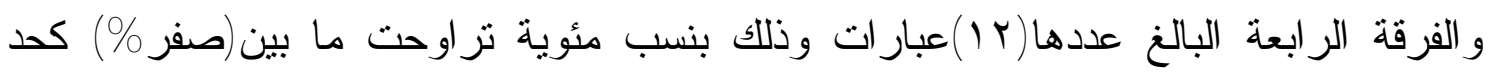
أعلى و ( 9 \%)كحد أدنى للعبار ات، وقد انحصرت اجابات معلمى التربية الموسيقية و المديرين

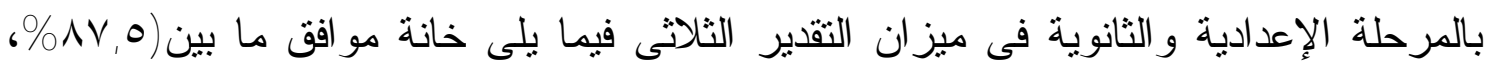

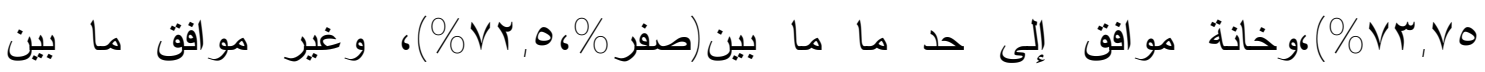

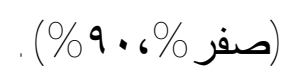




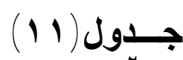

يوضح التكرارات والنسب المئوية وقيمة "كا"ا" ومستوي الدالأة لميزان التقدير الثالاثي لاستبيان

المحــور الخامس دور المشرف المدرسي أثناء فترة التدريب(ن = . ـ)

\begin{tabular}{|c|c|c|c|c|c|c|c|c|c|}
\hline \multirow{2}{*}{ مستوي الدلاية } & \multirow{2}{*}{ قيمـاة } & \multicolumn{2}{|c|}{ غُبِيز موأْهـق } & \multicolumn{2}{|c|}{ مو أُقْ إلىى حـ ما } & \multicolumn{2}{|c|}{ مو أْـــق } & \multirow{2}{*}{ 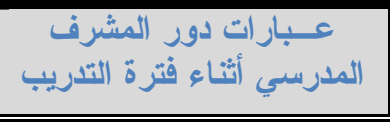 } & \multirow{2}{*}{ r } \\
\hline & & \% ن & 5 & \% ن & s & \% ن & s & & \\
\hline$\because, 1$ & $q, r r$ & $\%$ & $\varepsilon$ & $\% \leqslant 0$ & $m 4$ & $\% \circ$. & $\varepsilon$ & 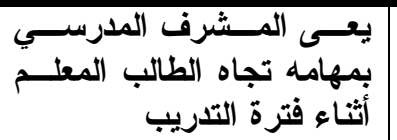 & 1 \\
\hline$\because \cdot 1$ & $r Y, r V$ & $\% 1$. & $\wedge$ & $\%$ \%r, vo & 01 & $\%$ \% , r० & $r^{\prime}$ & 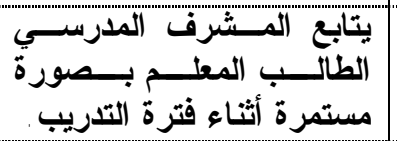 & r \\
\hline$\because, 1$ & $\Delta V, \leqslant Y$ & $\% \backslash \vee, 0$ & $1 \leqslant$ & $v_{1}, r_{0}$ & ov & $\% 11$, ro & 9 & 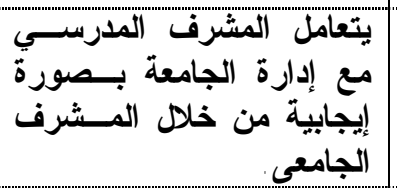 & $r$ \\
\hline$\because \cdot 1$ & $T V, r$. & $\% \backslash r, v o$ & 11 & $\vee \wedge, \vee_{0}$ & $r$ & $\% \vee, 0$ & 7 & 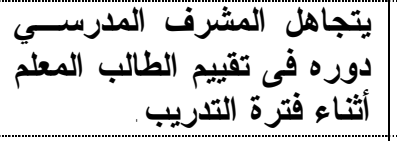 & 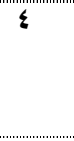 \\
\hline$\because, 1$ & $\varepsilon r, r V$ & $r r, 0$ & Y & $\% \circ$. & $\varepsilon$ & $\% 11, r_{0}$ & 9 & 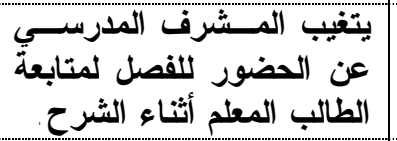 & $\circ$ \\
\hline$\because \cdot 1$ & $v_{\cdot}, v$ & $r, V_{0}$ & $r$. & $\% \diamond \wedge, \vee \circ$ & $\varepsilon V$ & $\% r, v o$ & $r$ & 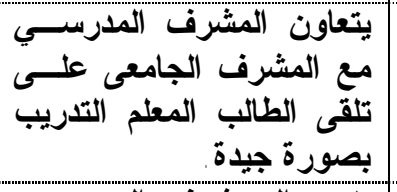 & 1 \\
\hline$\because \cdot 1$ & $\mid r r, \Lambda \varepsilon$ & $\% 4$. & $\leqslant \wedge$ & $\% r \wedge, \vee \circ$ & $\mu$ & $\% 1$, ro & 1 & 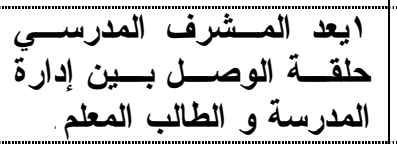 & V \\
\hline$\because \cdot 1$ & $|1 \leqslant, r|$ & $\% \circ 0$ & ؛ & $\% \leqslant r, \vee \circ$ & ro & $\% 1$, ro & 1 & 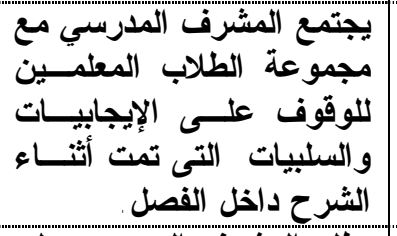 & 1 \\
\hline$\because \cdot 1$ & $1 r \mu, 11$ & $\% \circ v, 0$ & $\leqslant 4$ & $\% \leqslant 1, r \circ$ & $r r$ & $\% 1$, ro & 1 & 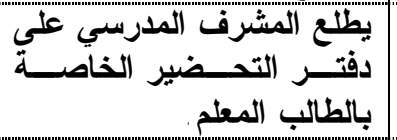 & 9 \\
\hline$\because, 1$ & $1.0,7 \pi$ & $\% \circ 1, r 0$ & $\leqslant 1$ & $\% \leqslant \wedge, \vee \circ$ & $r q$ & صفر\% & صفر & 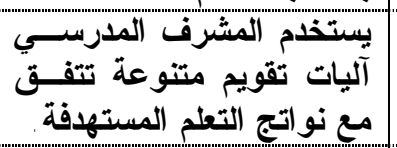 & '? \\
\hline$\because \cdot 1$ & $\Lambda_{\cdot}, 9 r$ & $\% \circ 0$ & $\leqslant \leqslant$ & $\% \leq 0$ & ry & صفر \% & صفر & 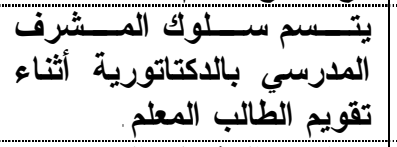 & 11 \\
\hline$\because \cdot 1$ & $r 44,9 q$ & $\% \wedge \vee, ०$ & $v$ & $\% \backslash r, 0$ & 1. & صفر \% & صفر & 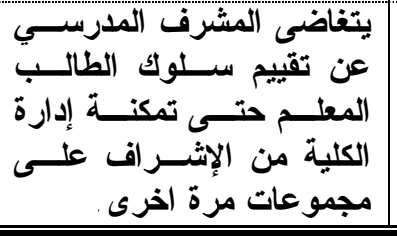 & Ir \\
\hline
\end{tabular}

\section{مجلة علوه وفنون الموسيقى -كلية التزبية الموسيقية - المجلد الاثنيز والأربعون - يناير •r.r}




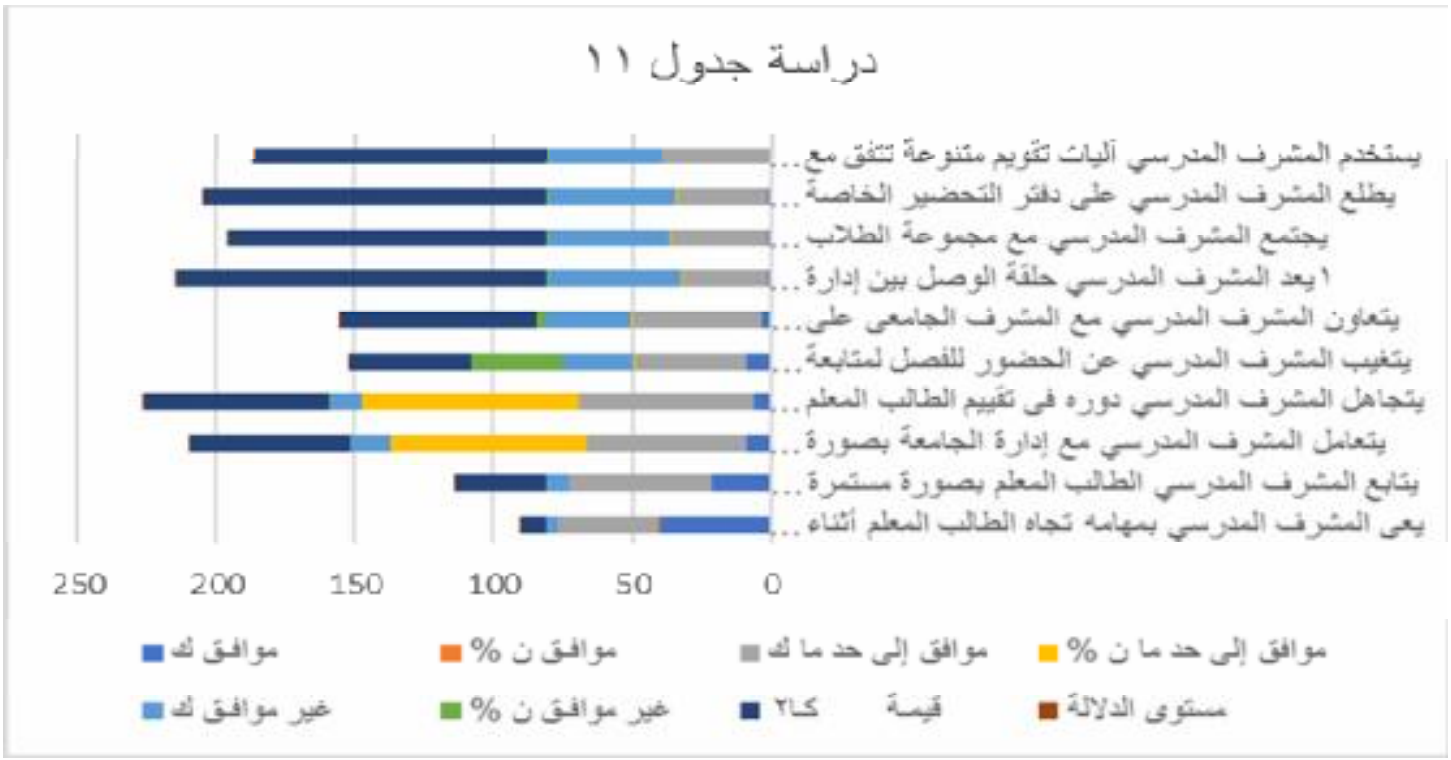

من خلال الجدول السابق يتضح أن قيمة" كا؟ "عند مستوى دلالة معنوية (0., •)ودرجة

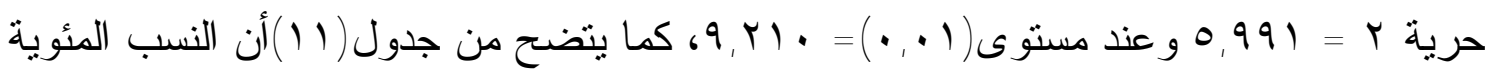

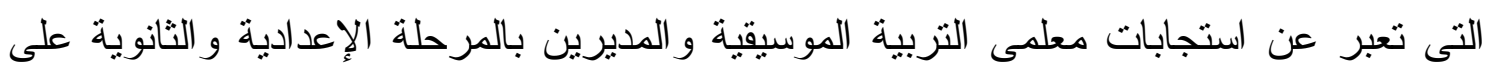
عبارات الإسنبيان الخاصة بقائمة المهارات التدريسية الخاصة بالطالب المعلم بالفرقة الثالثة

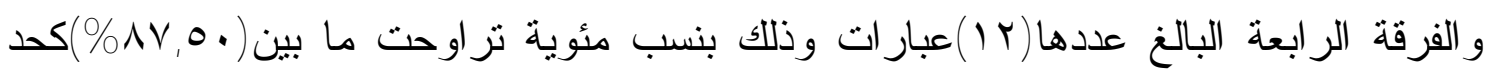
أعلى و (صفر \%)كد أدنى للعبار ات،وقد انحصرت اجابات معلمى التربية الموسيقية و المديرين بالمرحلة الإعدادية والثانوية فى ميزان التقدير الثثلثى فيما يلى خانة موافق ما بين

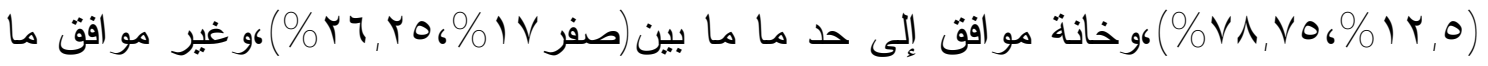
بين (\% ) 


\section{جدول (i )}

يوضح التكــرارات والنسب المئوية وقيمة "كآ" ومستوي الدلاكة لميزان التقدير الثثلاثي لاستبيان المحـور

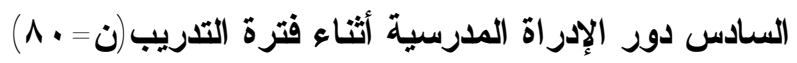

\begin{tabular}{|c|c|c|c|c|c|c|c|c|c|}
\hline \multirow{2}{*}{ مستوى الدلالة } & \multirow{2}{*}{ قيمـــــة } & \multicolumn{2}{|c|}{ غير موافــق } & \multicolumn{2}{|c|}{ موافق إلى حد ما } & \multicolumn{2}{|c|}{ موافــق } & \multirow{2}{*}{ عبــار ات دور الإدراة المدرسية } & \multirow{2}{*}{ b } \\
\hline & & \% ن & S & \% ن & ك & \% ن & ك & & \\
\hline., 1 & $11,1 \leq$ & $\%$ rr, 0 & 11 & $\% \bullet ५$, Y० & $\leqslant 0$ & $\%$ Y l, ro & IV & 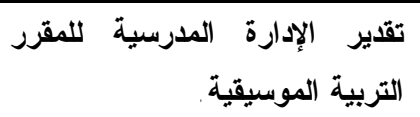 & 1 \\
\hline., 1 & $v 4,7 r$ & $\% \backslash$ r, 0 & 1. & $\% \vee r, v o$ & 09 & $\%$, r, vo & 11 & متابعة الإدارة المدرسة لمجموعات & $r$ \\
\hline., 1 & 09,09 & $\%$ rl, ro & iv & $\% \vee$. & 07 & $\% \wedge, \vee \diamond$ & $v$ & تعليــز الإدارة المدرســية وعــــم & $r$ \\
\hline$\cdot, 1$ & $T \leq, \wedge \leq$ & $\% r$. & $r \leq$ & $\%$ \% & or & $\%$ & $\varepsilon$ & 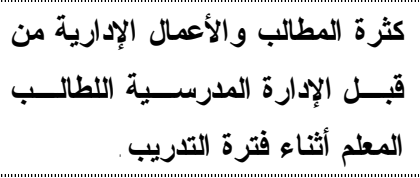 & $\varepsilon$ \\
\hline$\cdot, \cdot 1$ & 70,91 & $\% \leq r, 0$ & $r \varepsilon$ & $\% \circ$. & $\varepsilon$ & $\% \vee, ०$ & 7 & 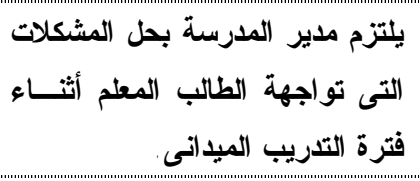 & 0 \\
\hline., 1 & Vr,Or & $\% r q, r \diamond$ & rI & $\% \vee r, 0$ & $\Delta \Lambda$ & $\% 1, r \diamond$ & 1 & مرونتها مع الطالب المعلم. الإدارة المدرسـية وعـــم & 7 \\
\hline.,+1 & $\wedge 1, \wedge r$ & $\% r v, 0$ & $r$. & $\% r r, 0$ & 0. & صفر & صفر & 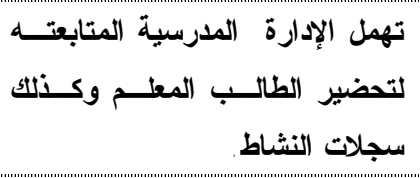 & V \\
\hline., 1 & $1 \cdot r, \Lambda$. & $\% \circ 1, r \circ$ & $\leqslant 1$ & $\% \leqslant v, 0$ & rs & $\% 1$, Y & 1 & 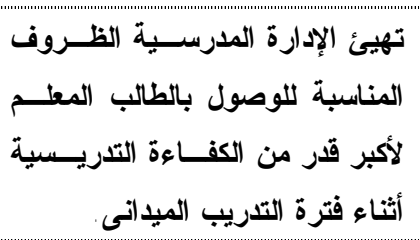 & $\wedge$ \\
\hline$\cdot, \cdot 1$ & $V \Psi, 9 r$ & $\% \circ r, v o$ & $\leqslant r$ & $\% \leq \neg, r \circ$ & rv & صفر & صفر & 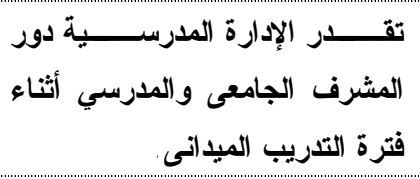 & 9 \\
\hline$\cdot, \cdot 1$ & ror,rr & $\% \wedge 1$, Y & 70 & $\% \backslash \wedge, \vee \diamond$ & 10 & صفر & صفر & 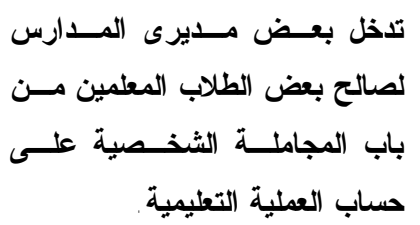 & 1. \\
\hline
\end{tabular}

\section{مجلة علوم وفنون الموسيقى - ملية التربية الموسيقية - المجلد الاثنين والأربعون - يناير •r.r.}




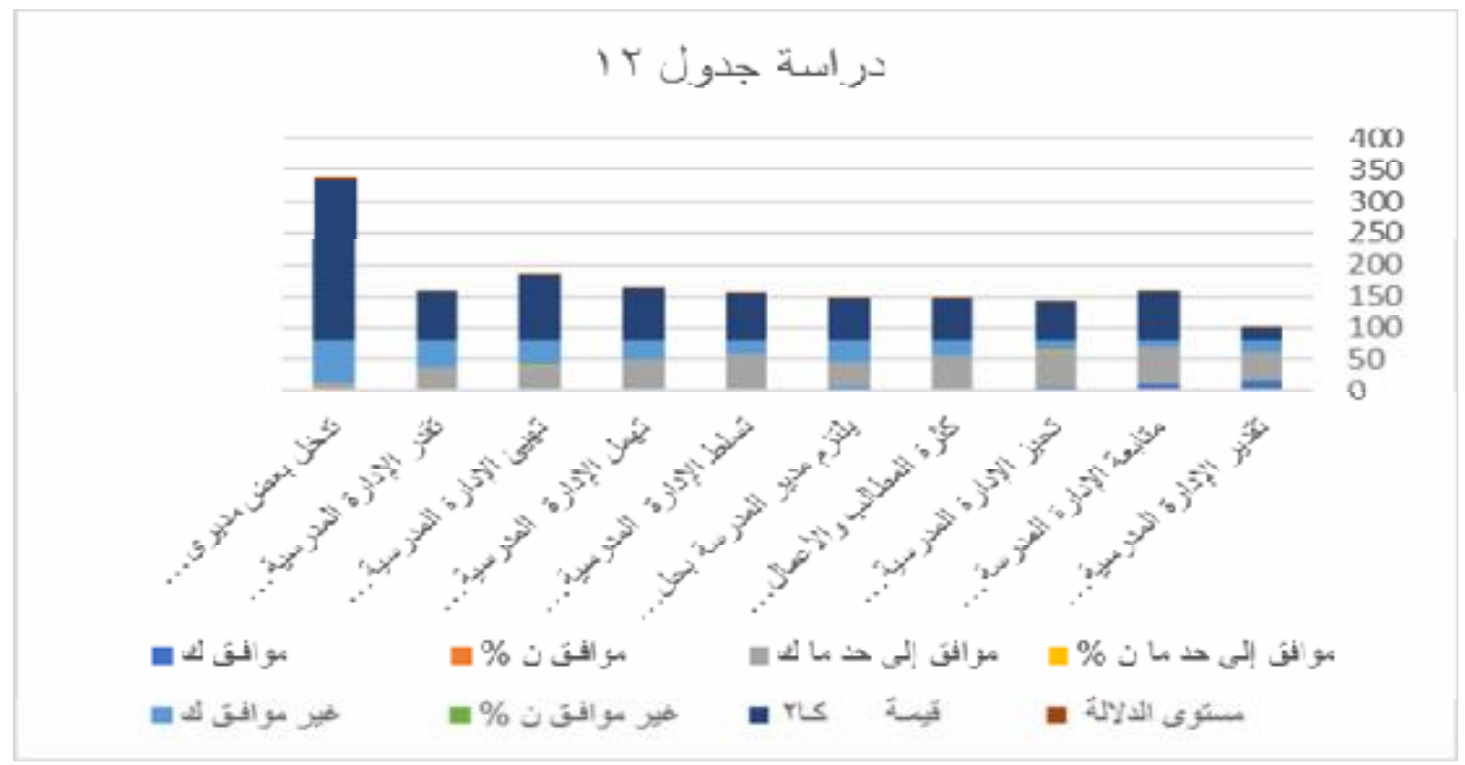

من خلال الجدول السابق يتضح أن قيمة" كا` "عند مستوى دلالة معنوية(0 •., )ودرجة

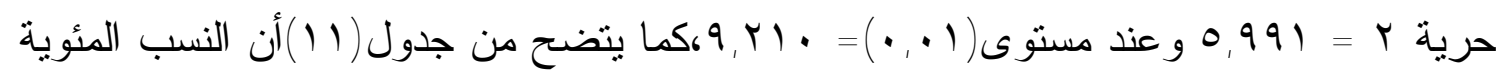
التى تعبر عن استجابات معلمى التزبية الموسيقية و المديرين بالمرحلة الإعدادية و الثانوية على عبار ات الإستبيان الخاصة بقائمة المهارات التدريسية الخاصة بالطالب المعلم بالفرقة الثالثة

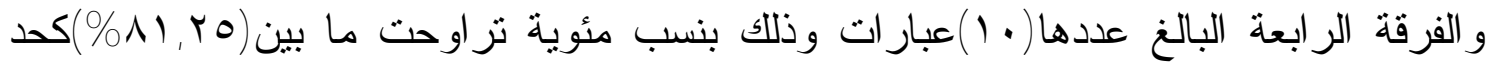
أعلى و (صفر \%) كحد أدنى للعبار ات،وقد انحصرت اجابات معلمى التربية الموسيقية و المديرين بالمرحلة الإعدادية و الثانوية فى ميزان التقدير الثلاتى فيما يلى خانة موافق ما مانى

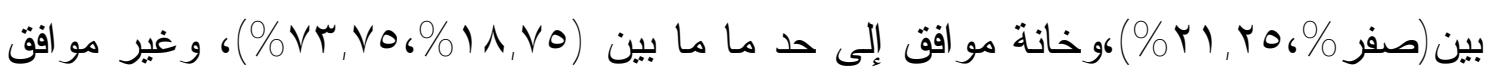

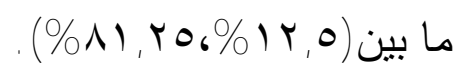

\section{ثانياً: تفسير النتائـــج ومناقشتها:}

للتحقق من صحة السؤ ال الأول للبحث و الذى ينص على " ما واقع الأداء فى التدريب الميدانى لطلاب الفرقة الثالثة و الفرقة الر ابعة شعبة التربية الموسيقية بكلية التزبية النوعية جامعة جنوب الو ادى خلال الدر اسة التتبعية " ؟، حيث تجز أت الإجابة على هذا السؤ ال الى( (ا) محاور رئيسه وهى كالتالى : 
المحسـور الأول: قائمة المهارات التدريسية الخاصة بالطالب المعلم بالفرقة الثالثــة و الفرقــة

$$
\text { الرابعة: }
$$

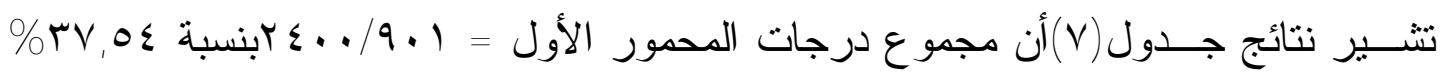

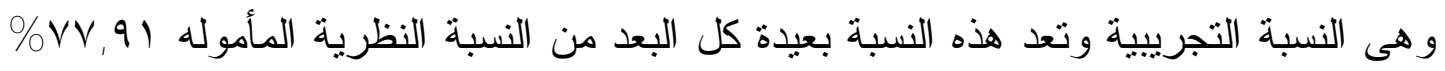

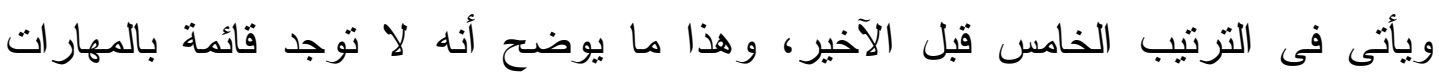

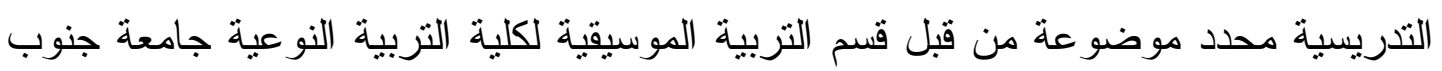

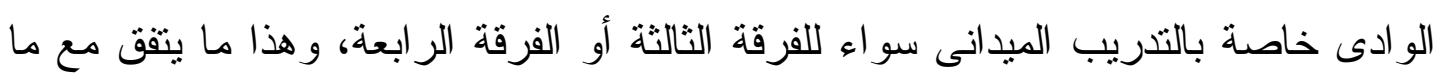

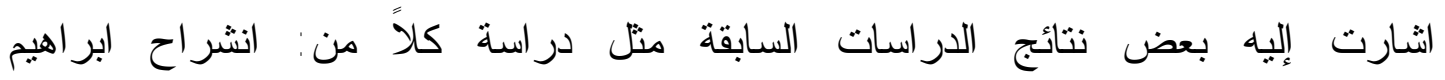

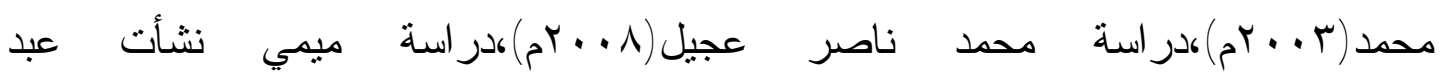

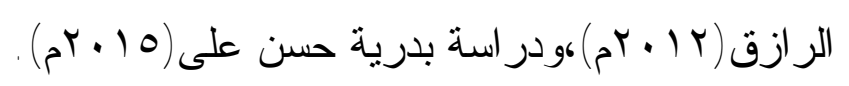

المحور الثانى: بطاقة الملاحظة للمهارات التدريسية الخاصة بالطالب المعلم بالفرقــة الثاثـــة

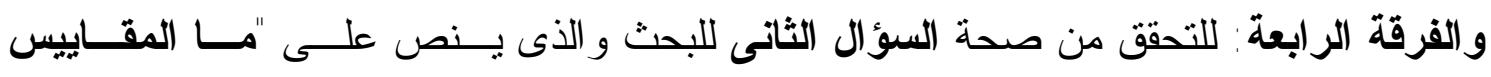

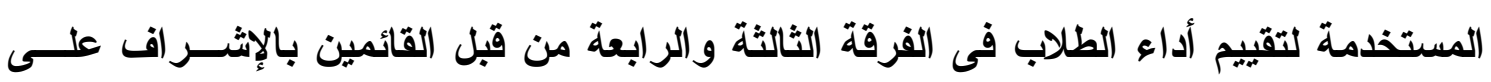

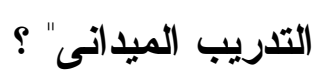

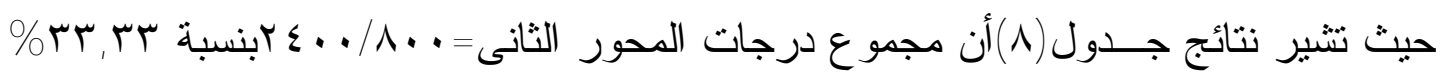

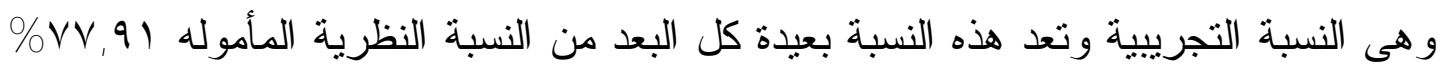

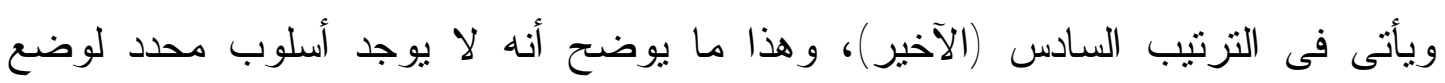

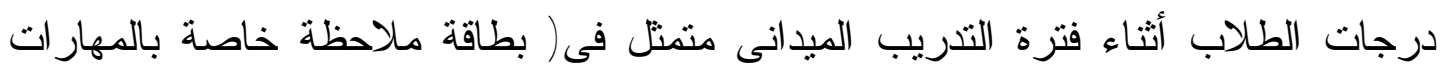

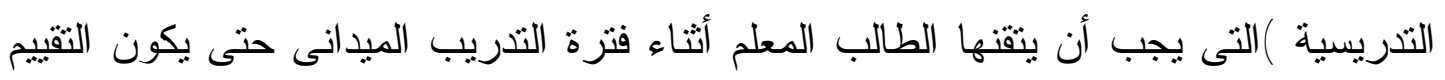

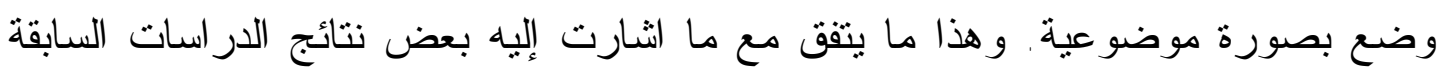

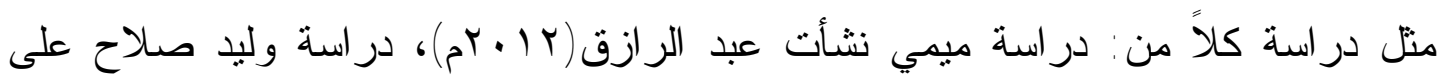

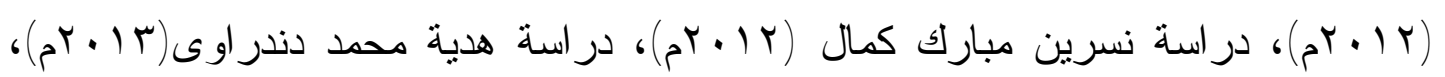

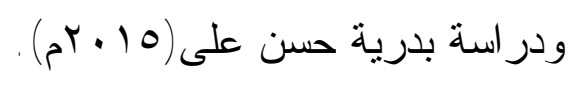


المحسور الثالث: الضوابط الخاصة بالطالب المعلم بالفرقة الثالثة والفرقة الر ابعة أثناء فترة

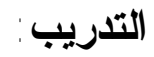

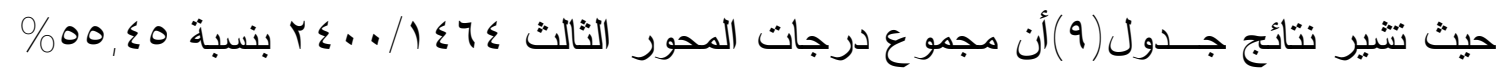

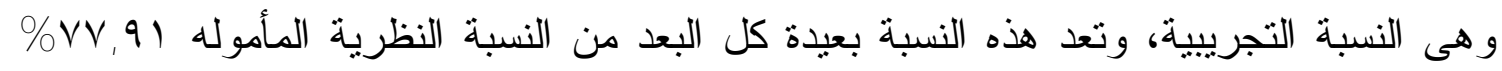

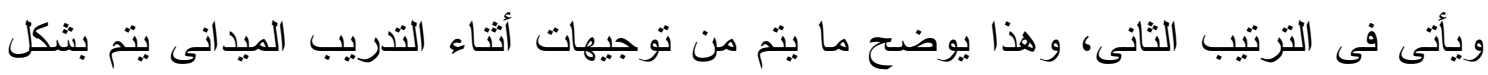
فردى واجتهادى وغير مقنن، كما أنه لا يوجد ميثاق أخلاقى يحكم أفعال الطالب المعلم أثناء

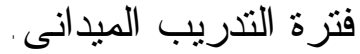

المحسور الرابــع: دور المشرف الجامعى أثناء فترة التدريب:

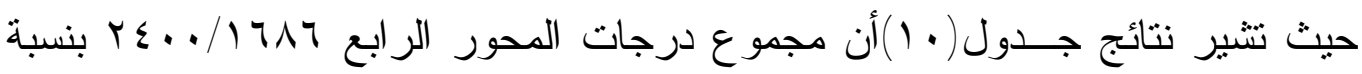
ع \% \% و وهى النسبة التجريبية، وتعد هذه النسبة بعيدة كل البعد من النسبة النظرية المأموله

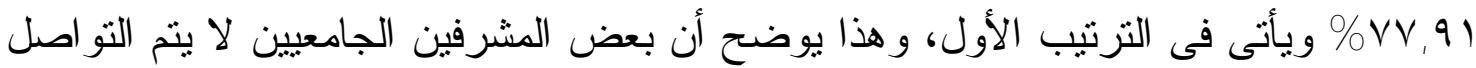

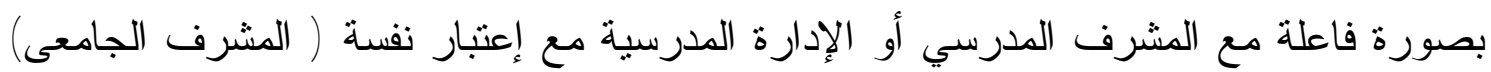
هو المسؤول عن الطالب المعلم أثناء فترة التدريب الميدانى. المحسـور الخامس: دور المشرف المدرسي أثناء فترة التدريب:

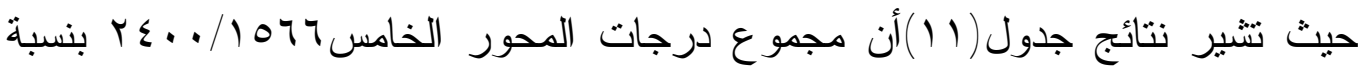

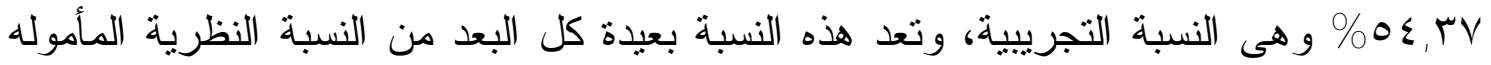
\% و و \% , 9

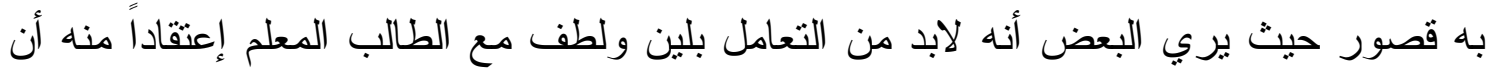
هذا هو الأسلوب المناسب حتى يرضى إدارة الكلية وتمكنة من الإثراف على مجموعات مرة أخرى، كما يري البعض الأخر انه لا توجد آليات محدد مقدمة من إدارة الكلية يتم من خلالها

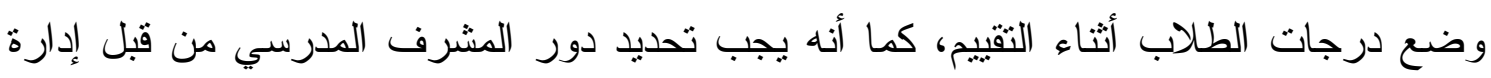
الكلية.

وترجع الباحثتين تفسير تلاك النتائج المشار إليها فى جدول( (1)أن تلك الأمور قد تعد تأثير سلبى على مسار العطلية التعليمية التزبوية بصفة عامة و إتجاهات المعلم نحو المهنة بصفة

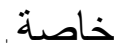


المحسور السادس: دور الإدراة المدرسية أثناء فترة التدريب:

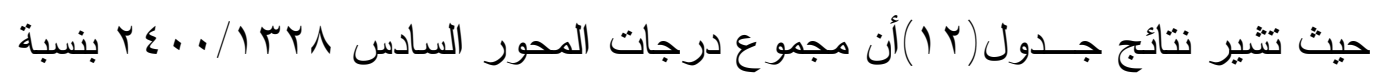
r r, \% \% وهى النسبة التجريبية، وتعد هذه النسبة بعيدة كل البعد من النسبة النظرية المأموله

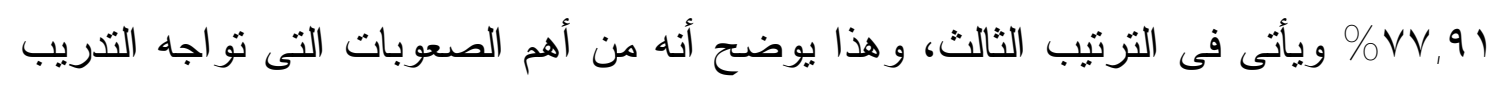

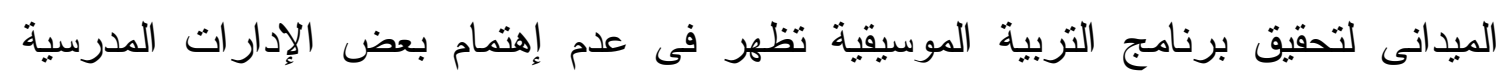

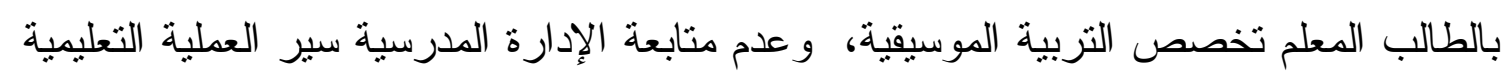
أثناء التدريب الميدانى، وكذلك تحيز الإدارة وعدم عدالتها فى التعامل مع الطلاب المعلميين.

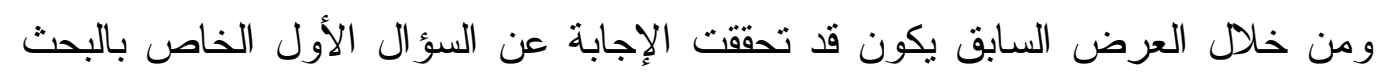

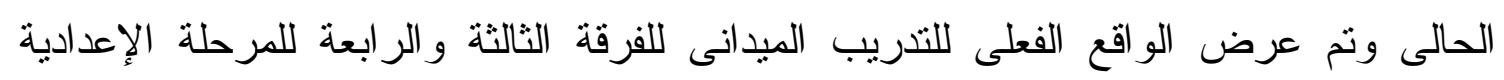
و الثانوية.

ومن خلال عرض الواقع يمكن إقتر اح المأمول من التدريب الميدانى فى ظل نظم الجودة و الإعنماد كما يلى: ومن جلى أولاً: قائمة المهارات الخاصة بالطالب المعلم أثناء فترة التدريب الميدانى: 1 - الفرقة الثالثة: نم تحديد القائمة الخاصة بمهار اتطات طالب الفرقة الثالثة أثناء التدريب الثاء

$$
\begin{aligned}
& \text { الميدانى من خلال الجدول(ب ا ()/التالى: } \\
& \text { جدول(r) }
\end{aligned}
$$

\begin{tabular}{|c|c|c|}
\hline المهارات الفرعية & المهارات الرئيسة & المسلسل \\
\hline 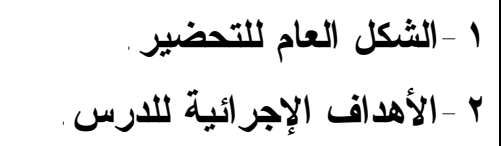 & التخطيط و الإعداد للارس & 1 \\
\hline 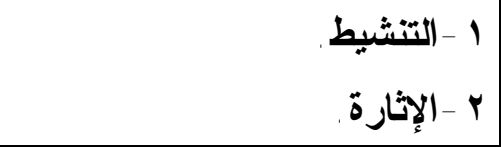 & مدخل التدريس & r \\
\hline 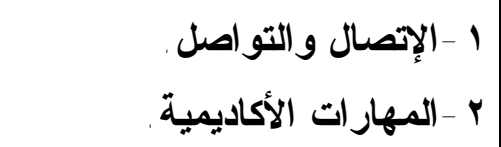 & الأداء التّريسى & $r$ \\
\hline 1 r -التنوع فى طرق التدريس. & طرق التدريس والوسائل التعليمية & $\varepsilon$ \\
\hline
\end{tabular}

قائمة المهار ات الخاصة بالطالب المعلم الفرقة الثالثة أثناء فترة التدريب الميدانى

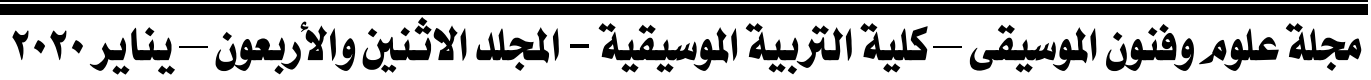




\begin{tabular}{|c|c|c|}
\hline المهار ات الفرعية & المهار ات الرئيسة & المسلسل \\
\hline 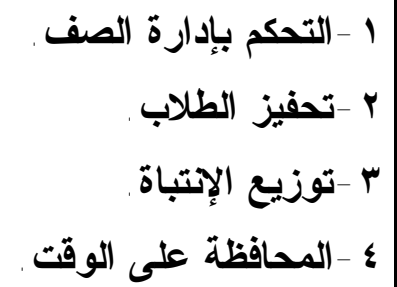 & إدارة الصف & 0 \\
\hline 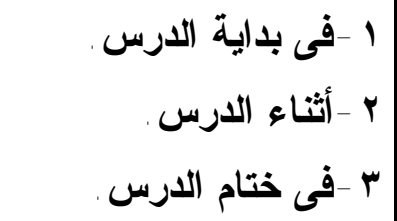 & التقييم & 9 \\
\hline r الألثل البيئة الصفية. & الأشطة الصفية واللاصفية & $v$ \\
\hline
\end{tabular}

ץ -الفرقة الرابعة: نم تحديد القائمة الخاصة بمهارات طالب الفرقة الرابعة أثناء التدريب

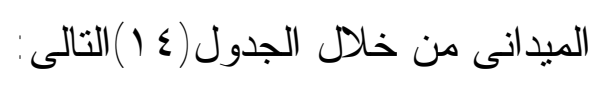

\section{جدول( 1 (1)}

قائمة المهارات الخاصة بالطالب المعلم الفرقة الرابعة أثناء فترة التدريب الميدانى

\begin{tabular}{|c|c|c|}
\hline كفايات التدريس الإبداعى التى يجب تنميتها لاى طلاب التربية الموسيقية & مراحل التدريس الإبداعى & كفايات التدريس \\
\hline 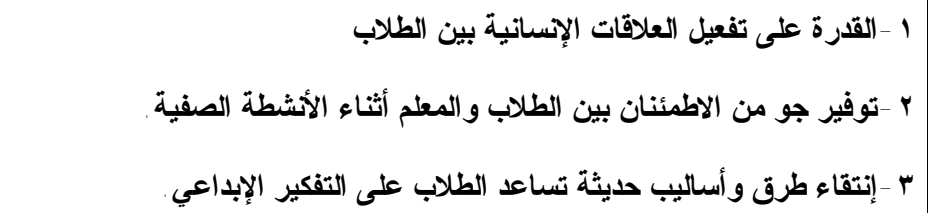 & 1 - إعداد بيئة صفية مناسبة & كفايات التدريس \\
\hline 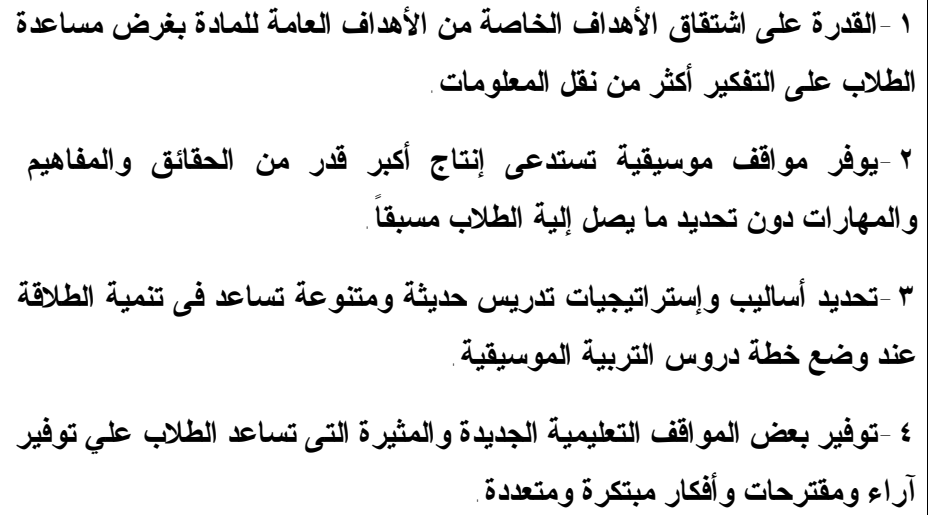 & r - التخطيط فى التدريس & \\
\hline
\end{tabular}

\section{مجلة علوم وفنون الموسيقى - كلية التربية الموسيقية - المجلل الاثنيز والأربعون - يناير •r.r.}




\begin{tabular}{|c|c|c|}
\hline كفايات التدريس الإبداعى التى يجب تتميتها لدى طلاب التربية الموسيقية & مراحل التدريس & كفايات التدريس \\
\hline 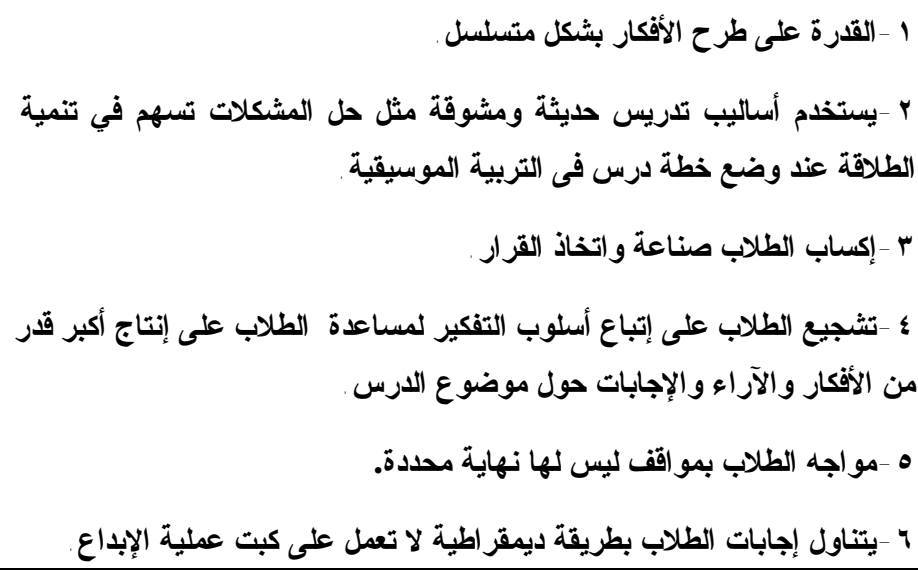 & r - التنفيذ فى التدريس & \\
\hline r r - بقيديم أسئلة متنوعة ومختلفة تستدعى مناقثات صفية فاعلة. & 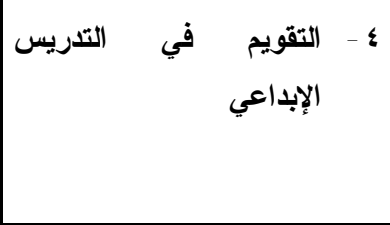 & \\
\hline 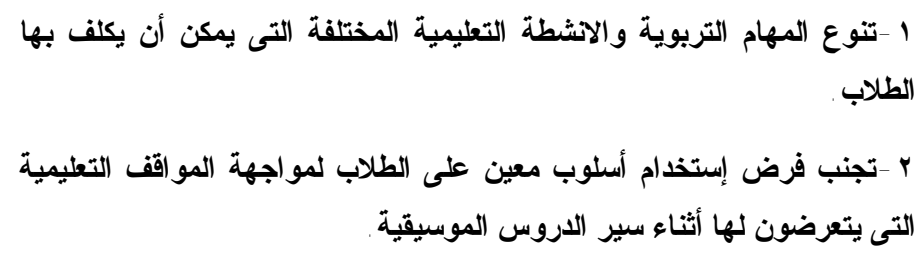 & 1 - إعداد بيئة صفيه صالحة & كفايات التدريس \\
\hline و الو -القدرة على إعداد خطة درس فى التربية الموسيقية يظهز فيها التنوع & r - التخطيط في التدريس & \\
\hline 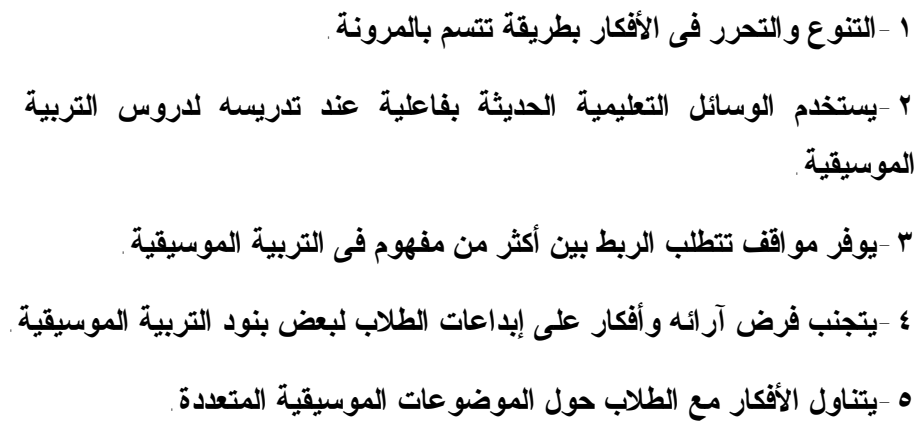 & r - التنفيذ & \\
\hline
\end{tabular}

\section{مجلة علوم وفنون الموسيقى -كلية التزبية الموسيقية - المجلد الاثنين والأربعون - يناير •r.r.}




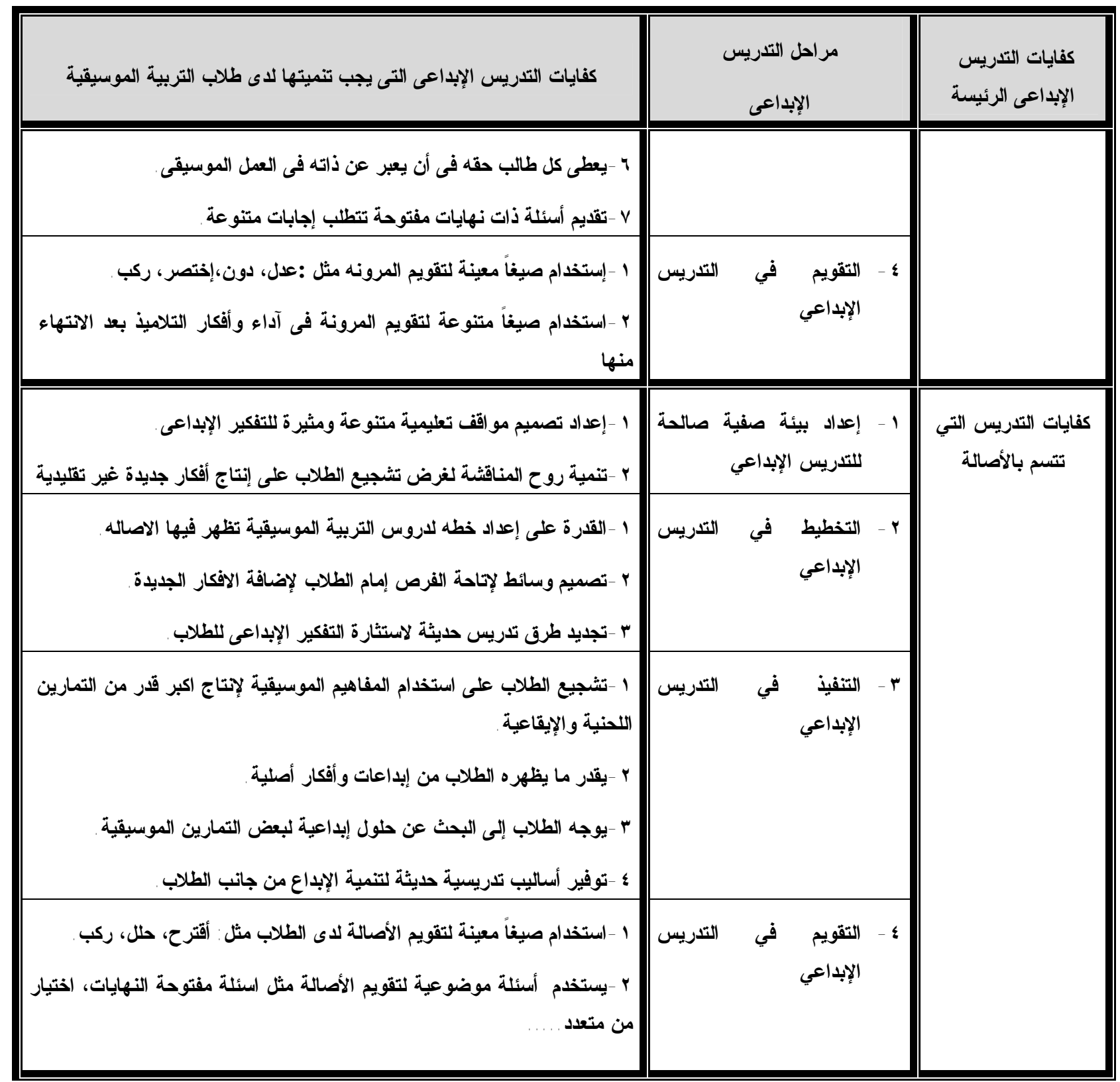

ثانياً: بطاقة الملاحظة الخاصة بالمهارات التذريسية لطالب المعلم أثناء فترة التذريب الميدانى:

1 -الفرقة الثالثة: نم تحديد بطاقة الملاحظة الخاصة بمهار ات طالب الفرقة الثالثة أثناء التدريب

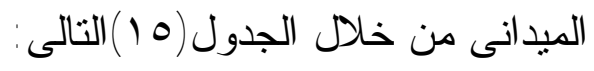




\section{جدول(10)}

بطاقة الملاحظة الخاصة بالمهارات التدريسية للطالب المعلم الفرقة الثالثة أثناع فترة التدريب

\begin{tabular}{|c|c|c|}
\hline المهارات الفرعية & المهارات الرئيسة & المسلسل \\
\hline 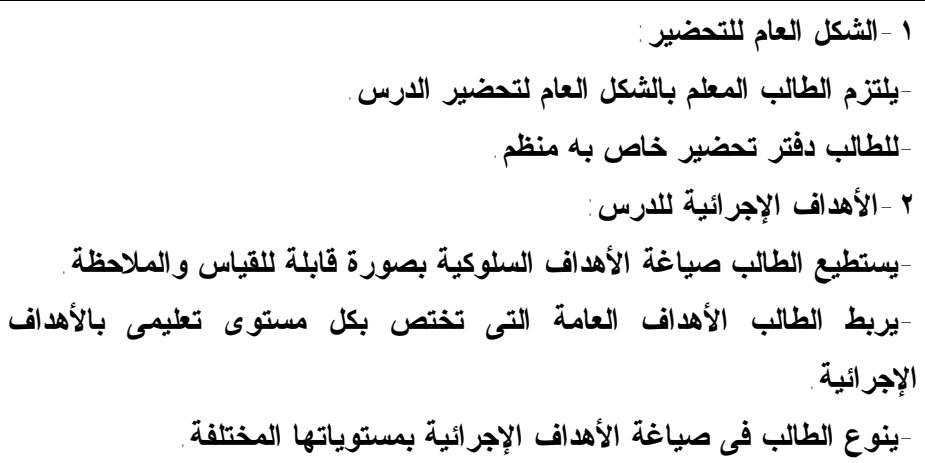 & التخطيط و الإعداد للارس & 1 \\
\hline 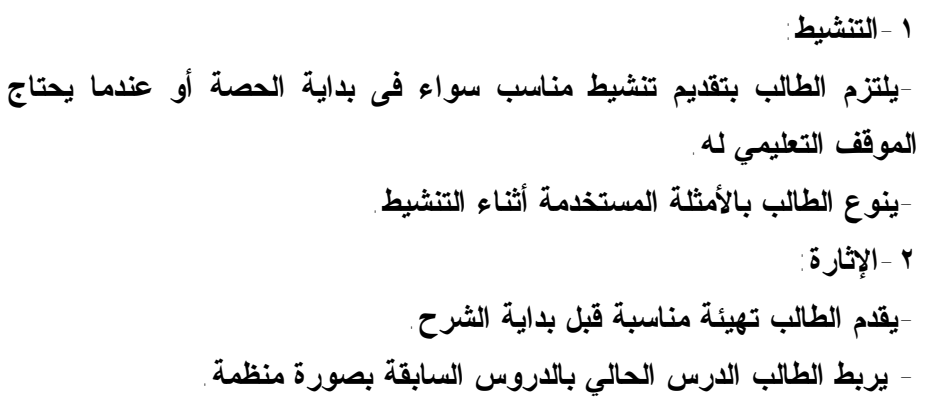 & مدخل التدريس & $r$ \\
\hline 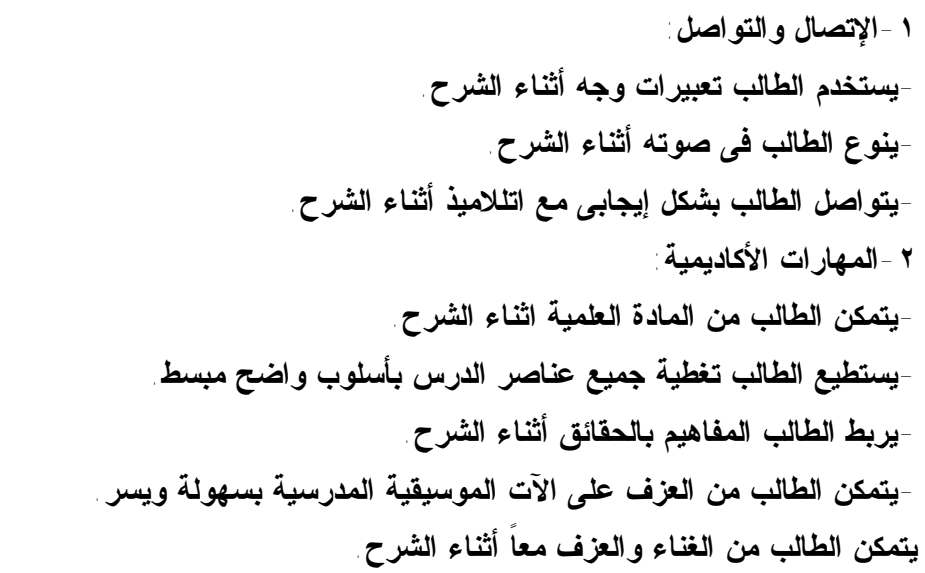 & الأداء التّريسى & $r$ \\
\hline 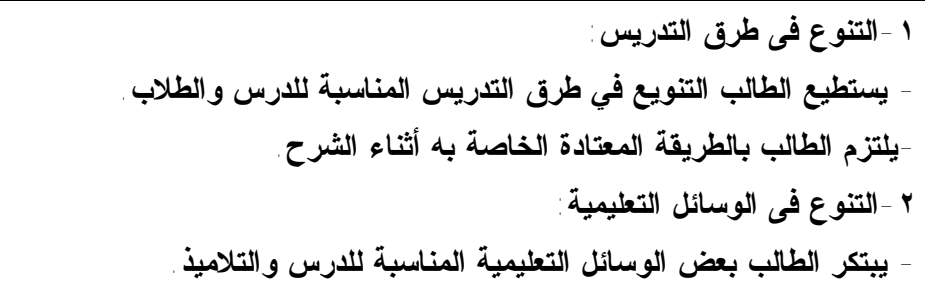 & طرق التّريس والوسائل التعليمية & $\varepsilon$ \\
\hline
\end{tabular}

\section{مجلة علوم وفنون الموسيقى -كلية التربية الموسيقية - المجلد الاثنين والأربعون - يناير •r.r.}




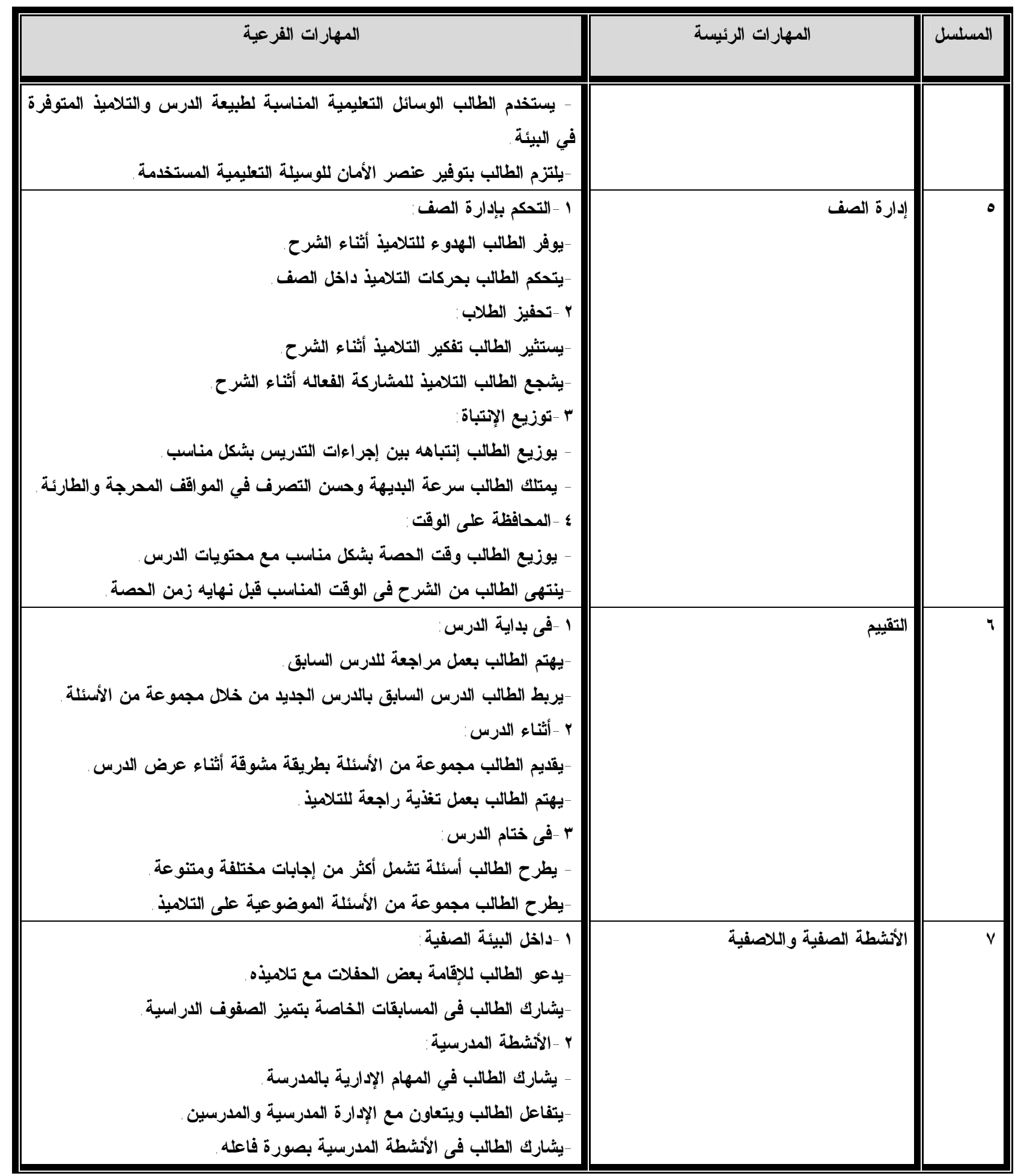

r -الفرقة الرابعة: تم تحديد بطاقة الملاحظة الخاصة بمهارات طالب الفرقة الرابعة أثناء التدريب الميدانى من خلال الجدول(ד ())التالى: 
جدول (17)

أولاً: ملاحظة أداة الطالب المعلم(إعداد بيئة صفية مناسبة للتريس الإبداعي)في التربية

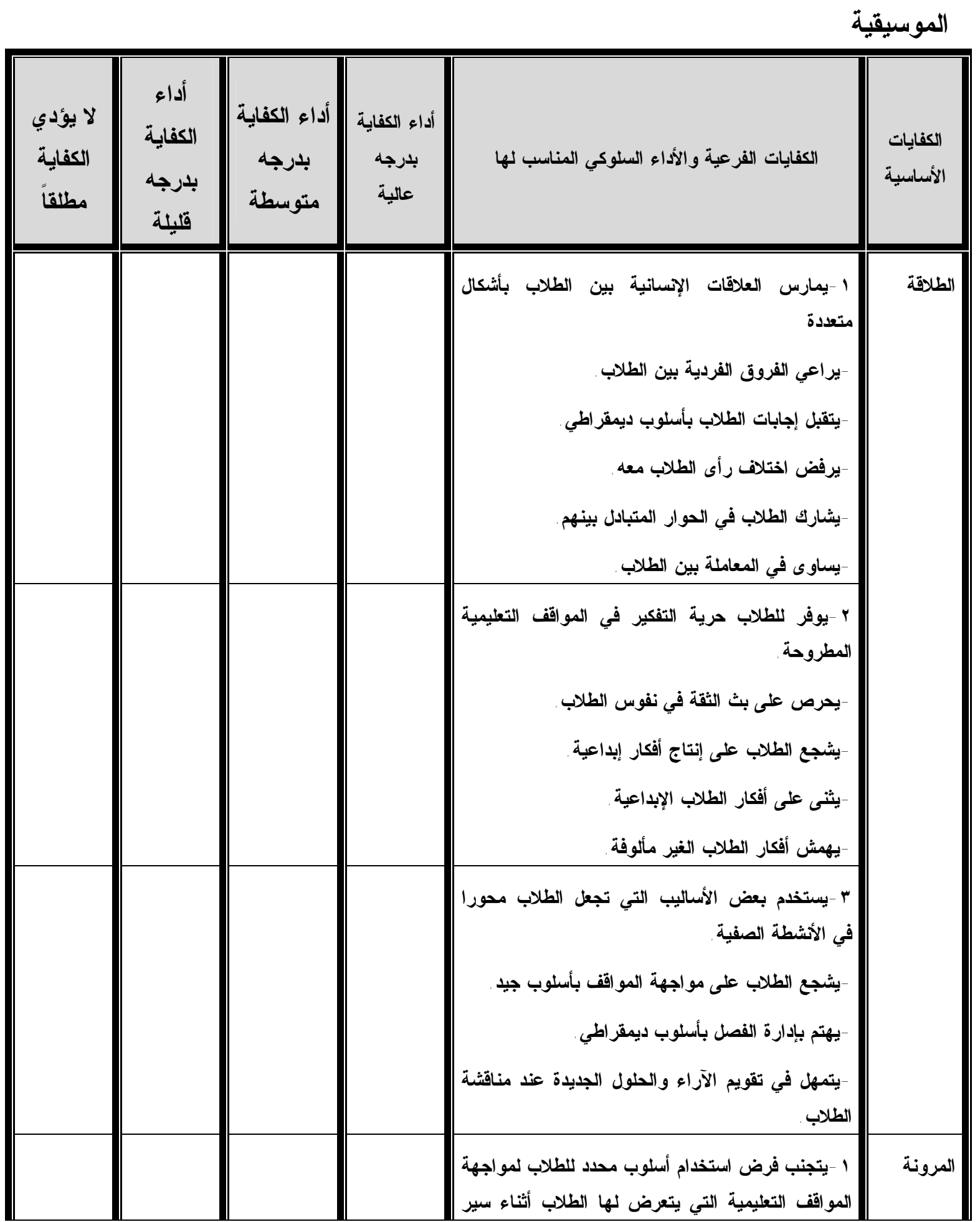




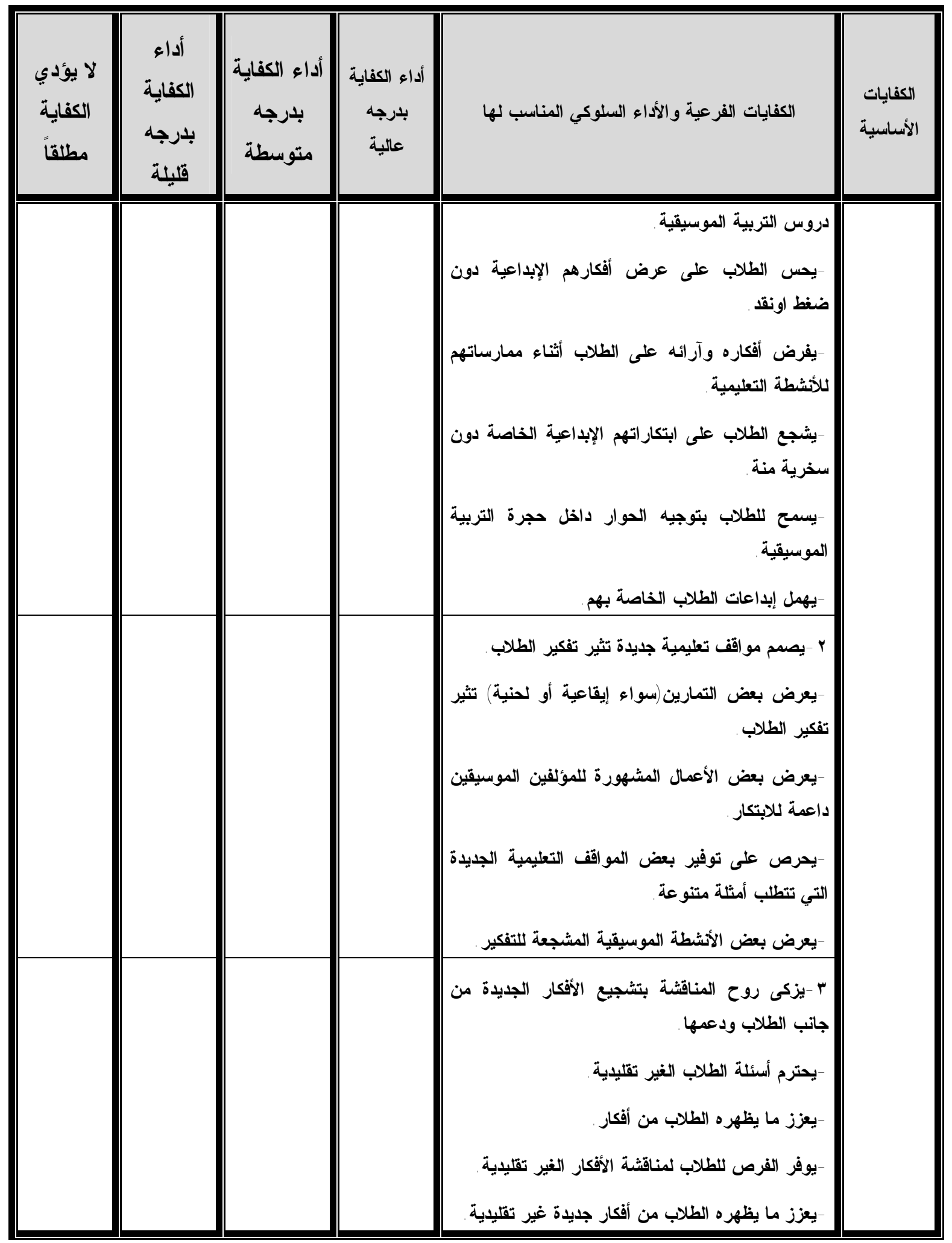

مجلة علوم وفنون الموسيقى -كلية التزبية الموسيقية - المجلل الاثنين والأربعوز - يناير بr.r. 
ثانياً: ملاحظة أداء الطالب/المعلم لكفاية(تنفيذ التثريس الإبداعى للتربية الموسيقية)

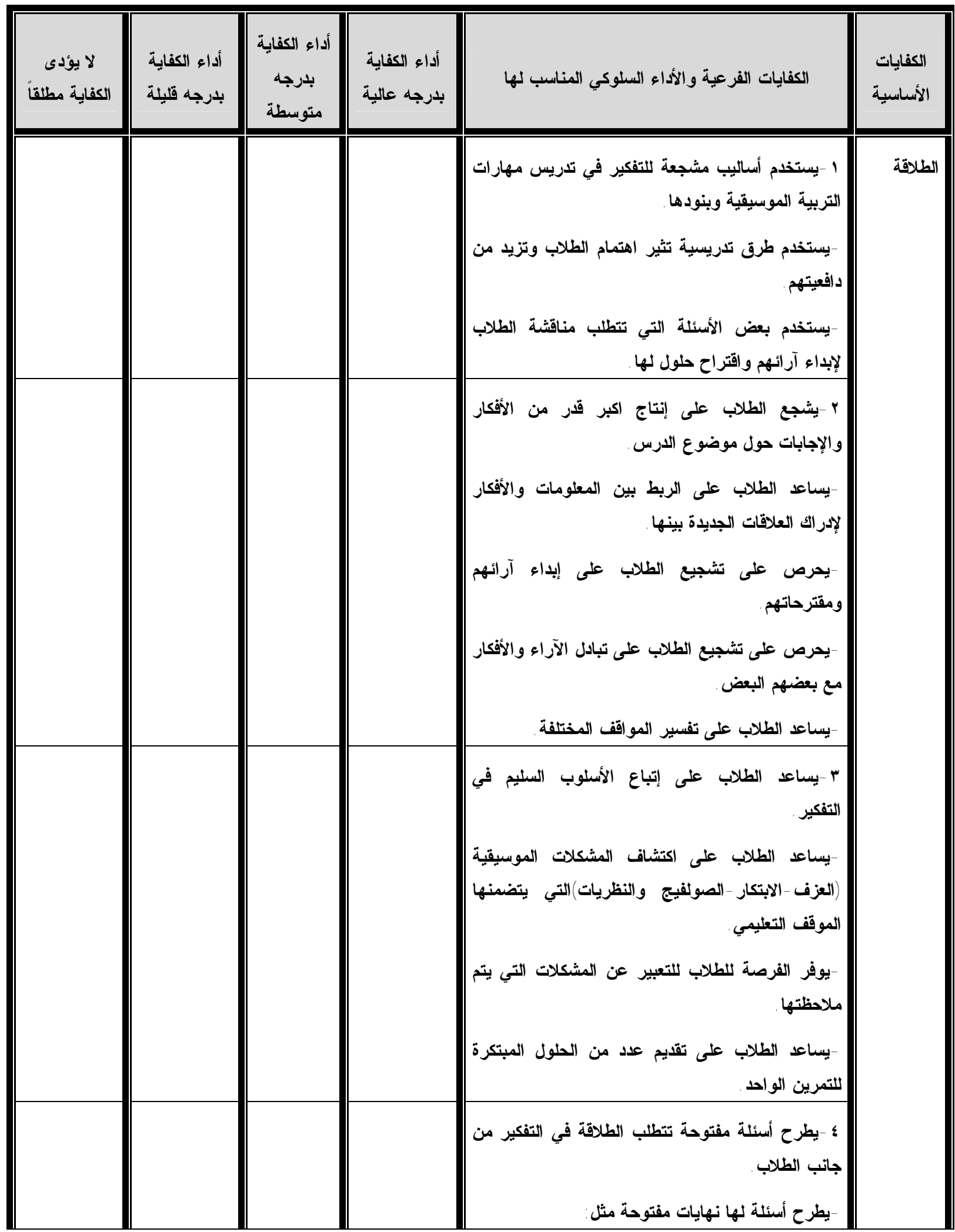

مجلة علوم وفنون الموسيقى -كلية التربية الموسيقية - المجلد الاثنيز والأربعون - يناير •r.r

$(1+\cdots)$ 


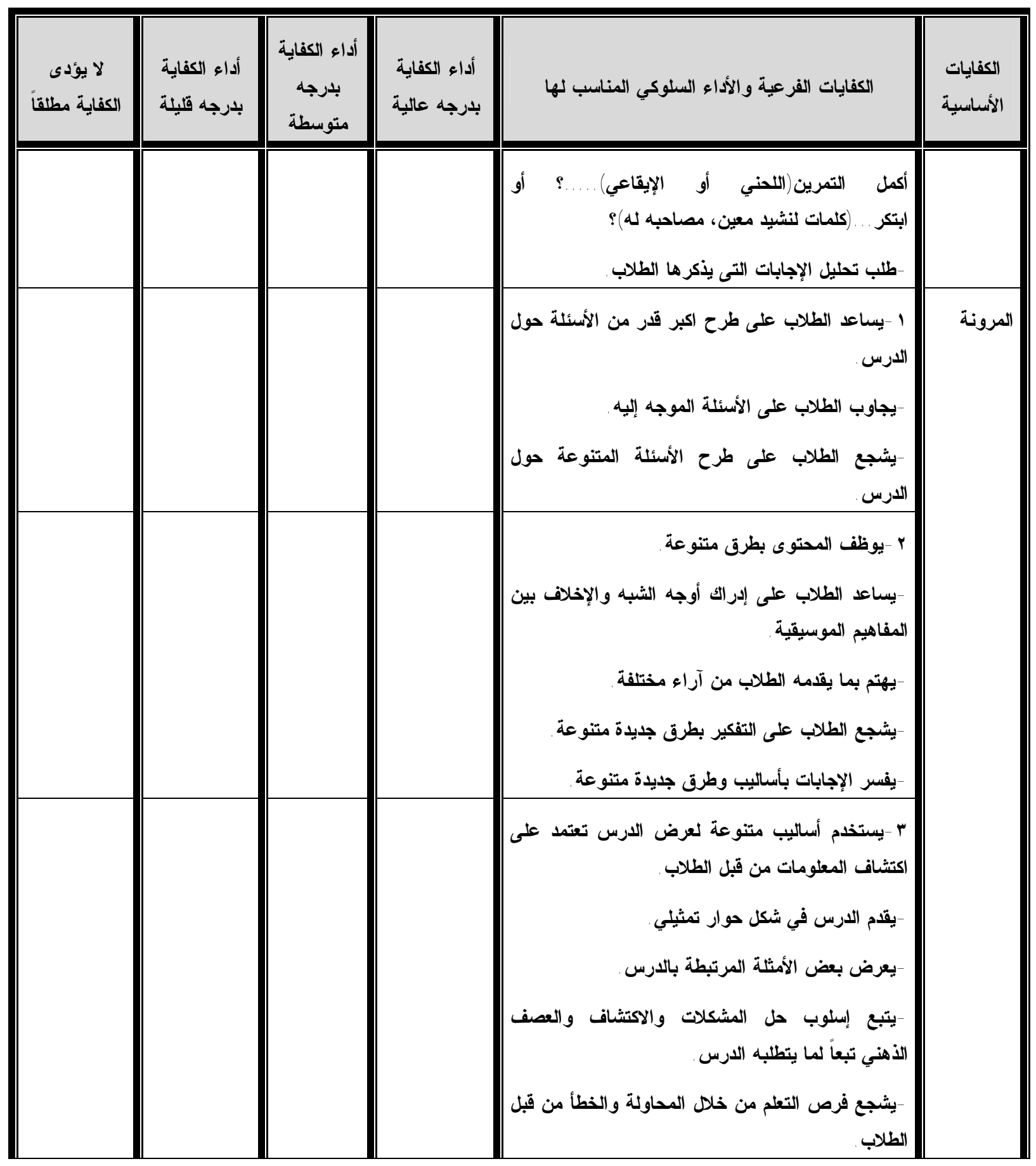




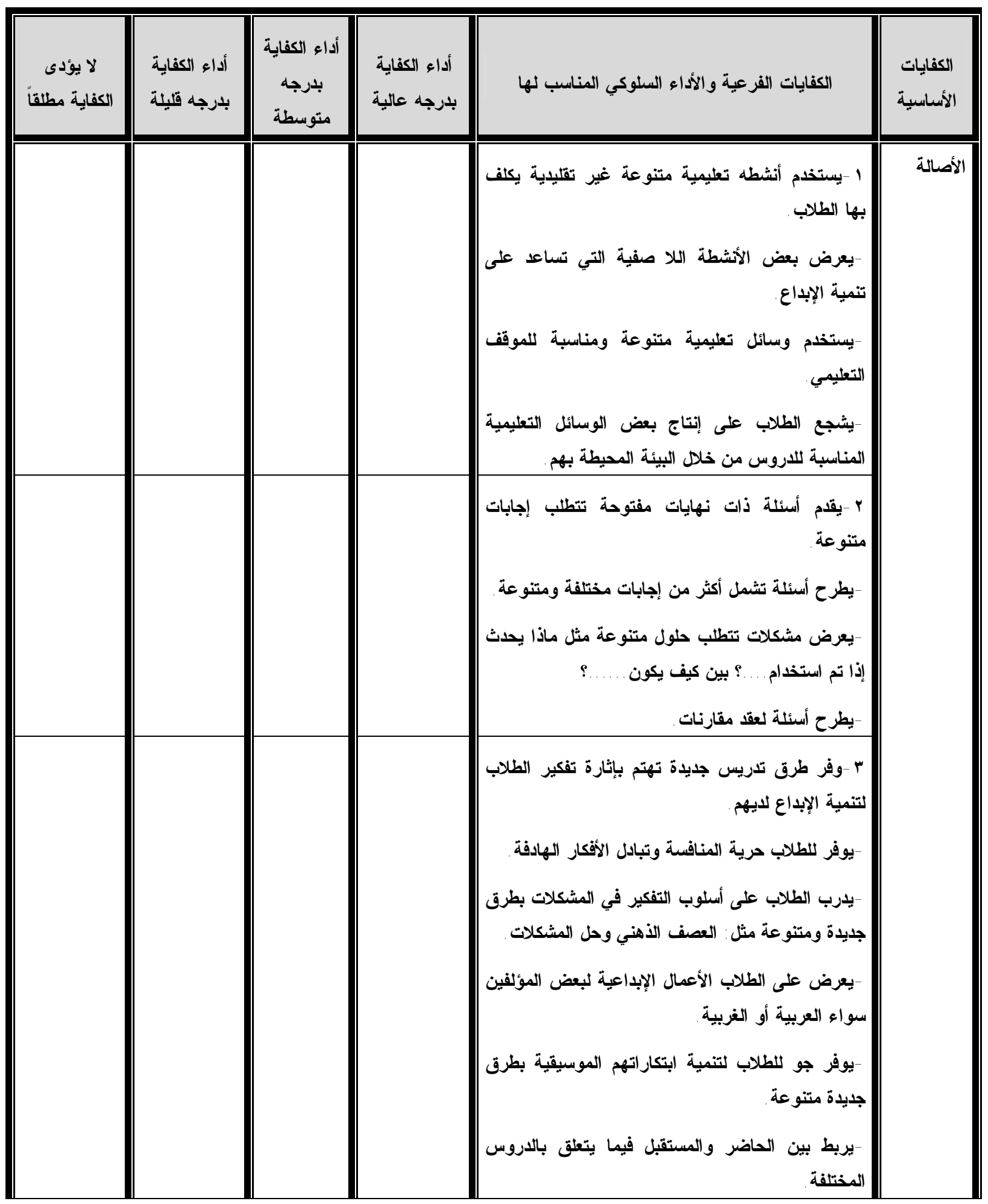




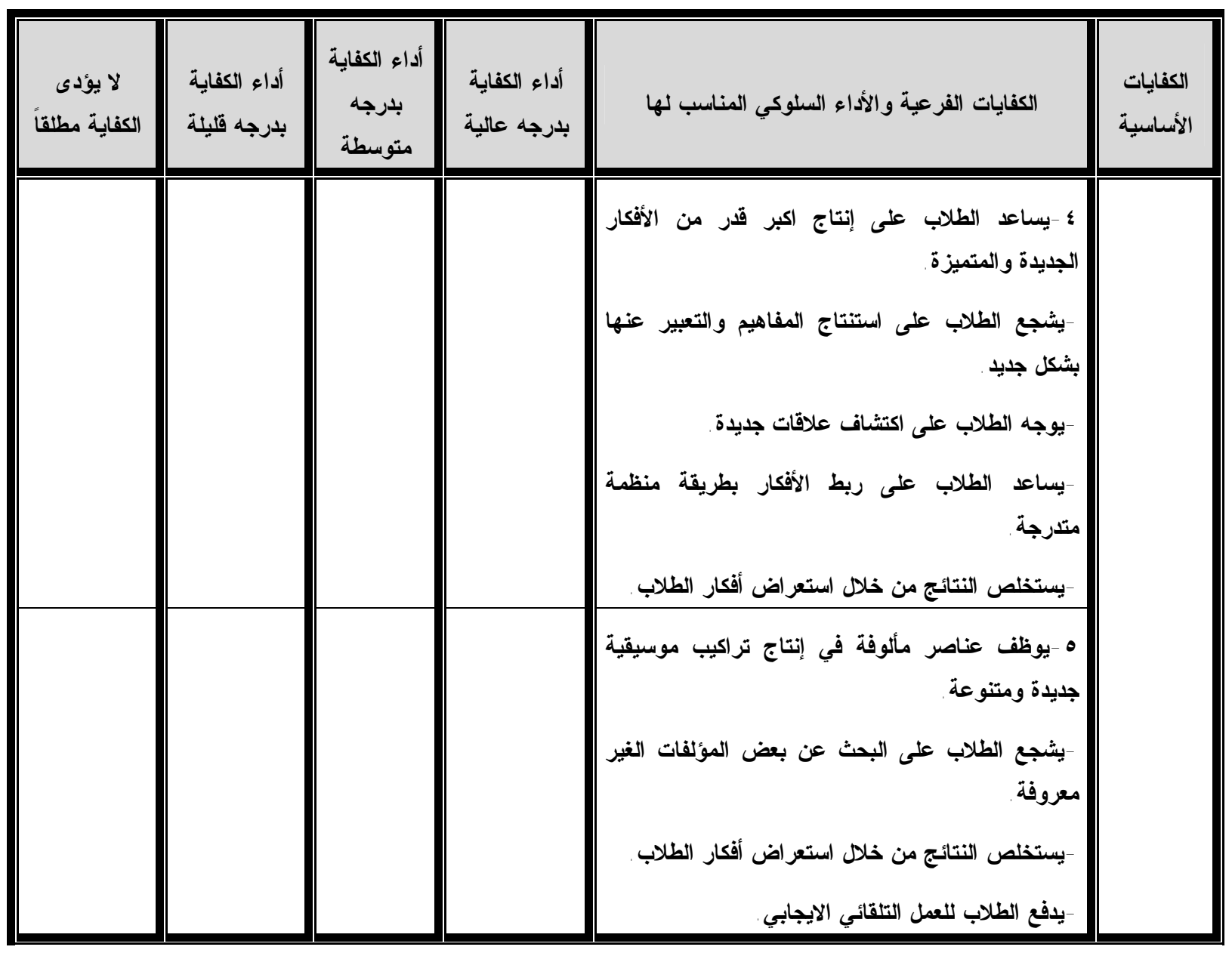

ثالثاً:ملاحظة أداء الطالب/المعلم لكفاية(التقويم في التدريس الإبداعي للتربية الموسيقية)

\begin{tabular}{|c|c|c|c|c|c|}
\hline لا لاؤدى الكفاية & أداو الكفاية & 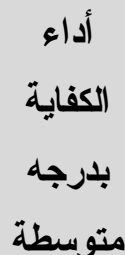 & أداء الكفاية & الكفايات الفرعية و الأداء السلوكي المناسب لها & الأسفاسياتة \\
\hline & & & & 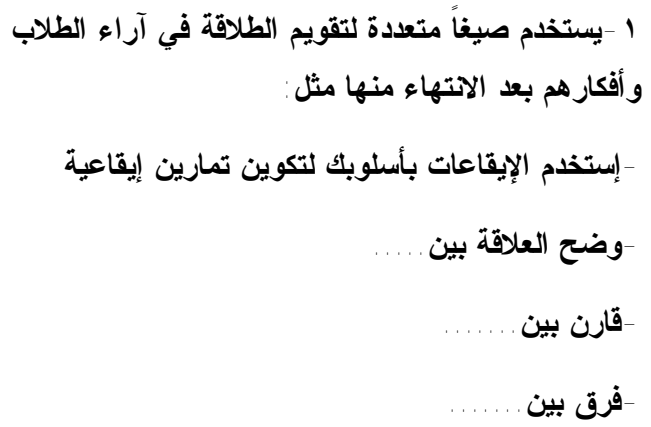 & 更 \\
\hline
\end{tabular}

مجلة علوم وفنون الموسيقى - كلية التربية الموسيقية - المجلل الاثنين والأربعوز - يناير بr.r.

$(I r, r)$ 


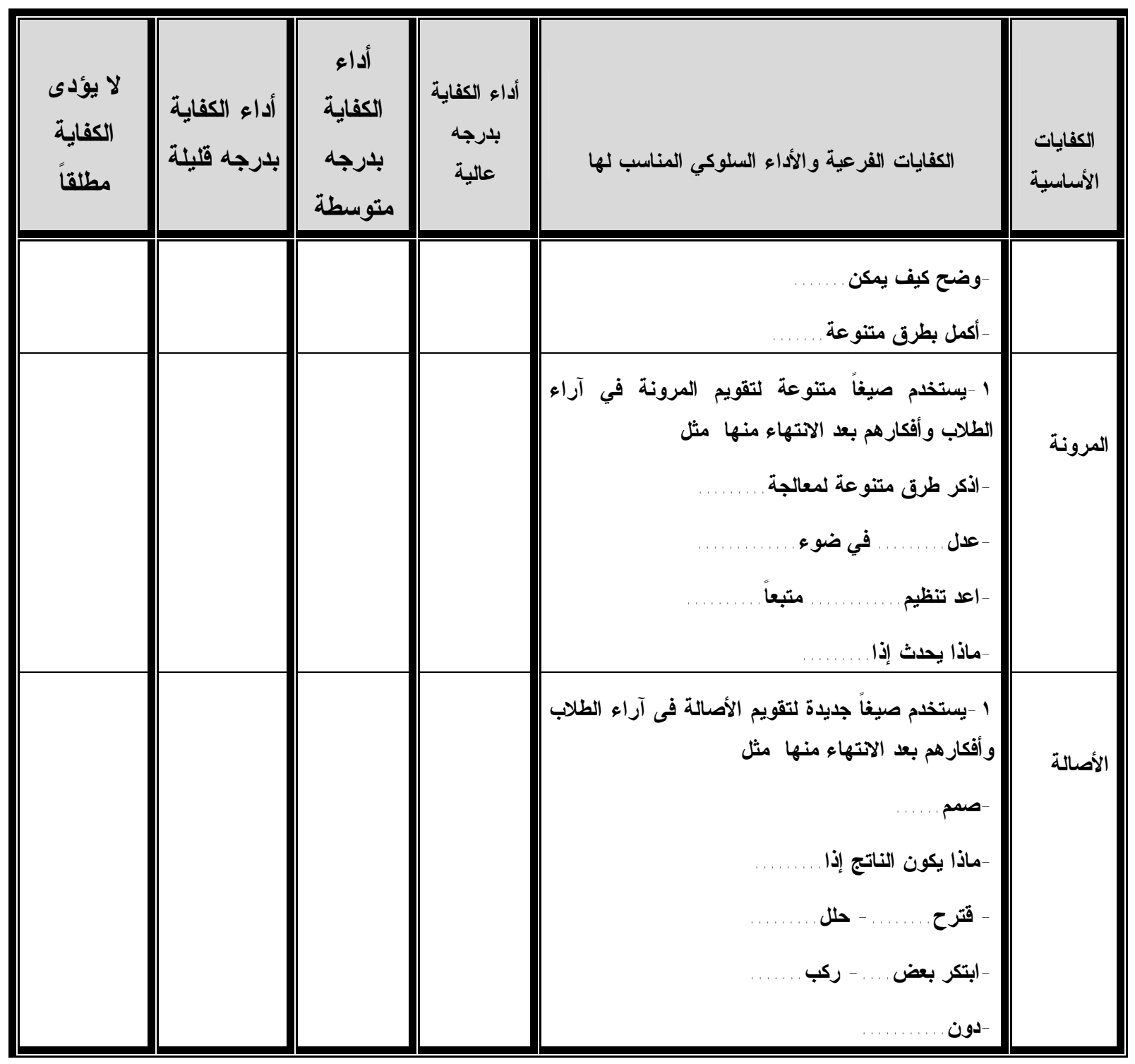

ثالثاً: الميثاق الإخلاقى للطالب المعلم أثناء فترة التدريب الميدانى للفرقة الثالثة والفرقة الر ابعة:

روية الكلية: التأهيل للتميز العلمي بما يحقق خريج قادراً على الدنافسة وبناء شر اكة فاعله تلبي احتياجات وطموحات المجتمع المهنية و البحتية. رسالة الكلية: نسعي الكلية لإعداد خريج متميز ذو كفاءة وفاعلية تعليمياً ومهنياً بما يلبي

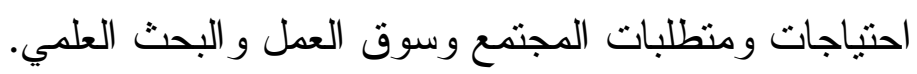




$$
\text { التدريب الميداني: }
$$

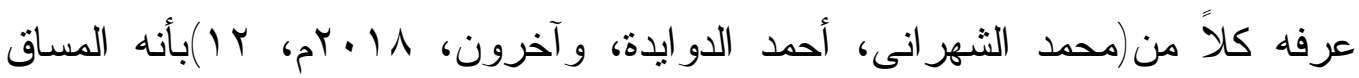

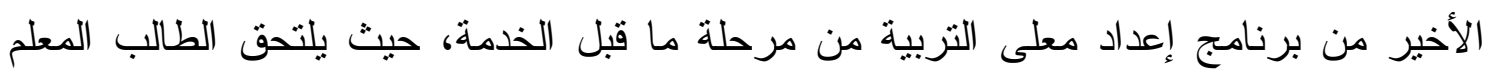

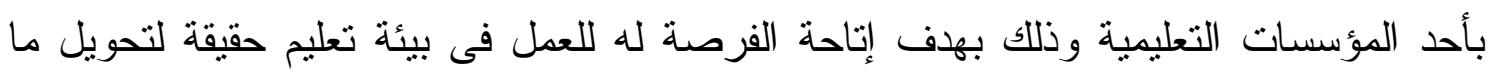

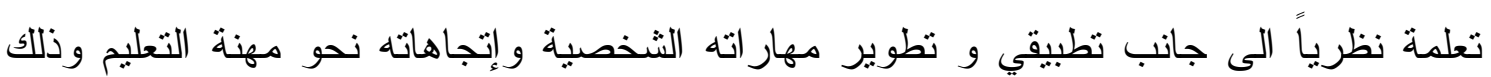
تحت إنثر اف تخصصى من قبل المشرف الجامعى و المدرسي.

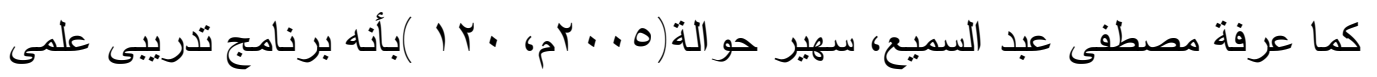

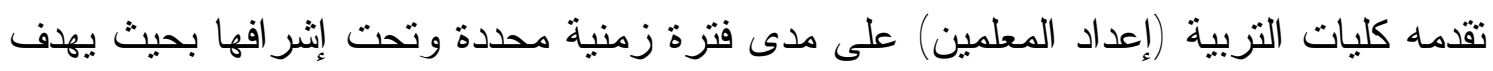

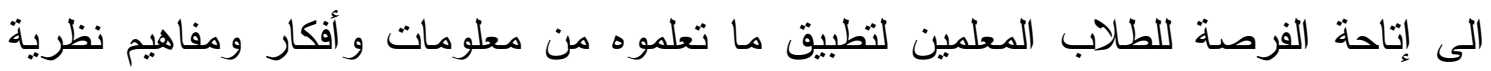

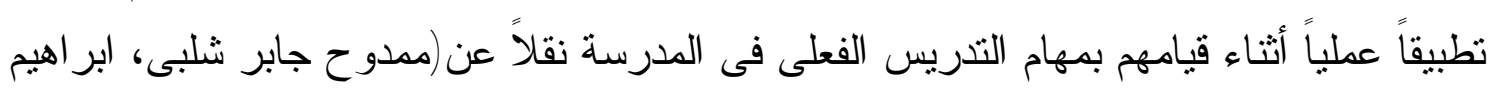

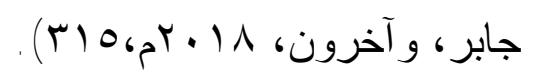
أهمية التدريب الميداني للطالب المعلم: ا بربط بين الجانب النظرى الذى تم تعلمة و التطبيق العملى المر اد بلوغه. r بعمل على تطوير الأسلوب الثخصى و المهنى للطالب المعلم . r بيؤدى الى الثعور بالرضا أو الثعور الإيجابى لاى الطلاب المعلمين نحو مهنة التدريس.

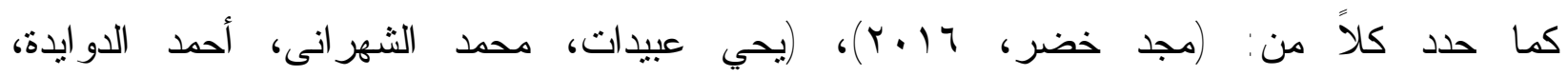

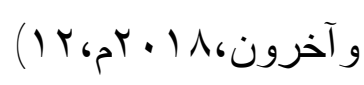
أهمية التذريب الميدانى بأنه: ع بسيهم فى إعطاء الطلاب المعلمين الفرصة ليكونو ا جزءاً من معلمى المستقبل. 0 فهم خصائص وحاجات الفئة التى يعمل معها بشكل أكبر . ج -نطبيق استر اتيجيات التعليم و التعلم المختلفة. V تطبيق أساليب الثقييم الرسمى و غير الرسمى كالإختبار ات و الملاحظة. ᄉ -إعداد الخطة التزبوية و التعليمية الفردية وتطبيقها.

\section{مجلة علوم وفنون الموسيقى - ملية التربية الموسيقية - المجلد الاثنين والأربعون - يناير •r.r}


9 -فهم نظام العمل المتبع داخل المدرسة. • ا -معرفة الوسائل و الأدوات التعليمية والأشطة المختلفة التى يجب العمل بها. r ا -اكتساب إدارة الصف بشكل جيد. rا -نطوير آليات استغلال وقت الجلسة التعليمية بشكل جيد. ـ ا -نطوير آليات لحل المشكلات التى تعترضه أثثاء التنريس.

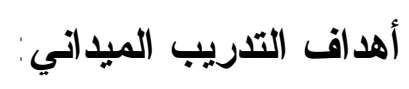

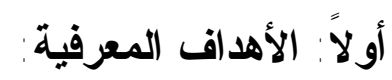

( -التعرف على أهداف المر احل التعليمية المختلفة المرحلة الإعدادية،المرحلة الثانوية). r -إكساب الجوانب المعرفية لأبعاد عملية التذريس والأنثطة الصفية واللاصفية التى يستطيع ممارستها عملياً داخل المؤسسة التعليمية. r -معرفه حقوق المعلم وواجباته،وحدود العلاقة بين المعلم والمتعلمين والمعلم ومدير المدرسة وزملائة و العاملين فى المدرسة، وكذلك أولياء أمور المتعلمين . ع -التعرف الى أدوار المعلم ومدير الددرسة والأختصاصين و العاملين ومسؤلياتهم . ه -إكتساب معلومات حول الإدارة الصفية و المدرسية الناجحة من و اقع التنريب الميدانى. 7 - إكتساب معلومات حول طبيعة البيئة المدرسية وقو اعد العمل بها و المشكلات المنوقع حدوثها وكيفية التعامل معهم.

V - التعرف على طرق و أساليب التدريس السائدة فى المؤسسات التعليمية( المدرسة) و العمل على تطوير ها وتكيفها لملائمة قدر ات المتعلمين.

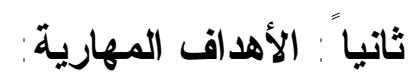
ا -تتمية مهارة التعرف على طبيعة المتعمين. r -تتمية مهارة إدارة وضبط الصف. r - تتمية مهارة التدريس و أساليب التعامل مع المتعلمين.

\section{مجلة علوم وفنون الموسيقى -كلية التربية الموسيقية - المجلد الاثنين والأربعون - بناير •r.r}




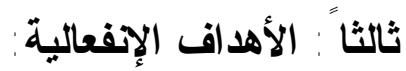

1 -الإلتز ام بأخلاقيات مهنة التدريس داخل المدرسة. r -الإهتمام بالسلوك العام و المظهر الخارجى للطالب المعلم. r - تتمية الإتجاهات نحو مهنة التدريس. ـ -تقبل النقد و التوصيات من الآخرين ذوى الخبرة. ه -التعاون مع العاملين فى المدرسة. 7 -الحماس و النشاط داخل البيئة المدرسية. V -التفاعل الإيجابى مع الآخرين داخل المدرسة. 1 فهم و احتر ام التسلسل الوظيفى و الإدارى لقو اعد المهنة(يحي عبيدات، محمد الثهر انى، أحمد

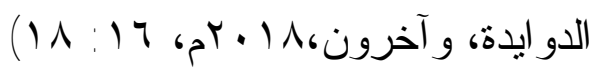
مسؤليات ومهام المشرف الجامعى تجاه الطالب المعلم: 1 ا-تزويد الطالب المعلم بخطة التدريب الميدانى. r -مناقثة الطالب المعلم بمتطلبات التدريب الميدانى. r -تزويد الطالب المعلم بالنماذج الخاصة بالتدريب الميدانى وشرحها لهم. ع -القيام بعدد كاف من الزيار ات الإثر افية لمجموعات الطلاب بالمدارس. ه -التتسيق مع الإدارة و المعلم المدرسي حول مسؤليات ومهام الطالب المعلم. 7 -التو اصل المستمر مع الطلاب المعلمين في كافة مر احل التذريب الميدانى. V -إرشاد الطالب المعلم الى مصادر تعليمية متتوعة تساعدهم فى تحقيق منطلبات التدريب الميدانى. ᄉ -عقد إجتماعات دورية فى القسم لمناقثة مجريات التدريب الميدانى. 9 -مساعدة الطالب المعلم على حل المشكلات التى تواجهم أثناء التنريب الميدانى. • ا -دعم وتتظيم العلاقة بين الجامعة و المؤسسات التعليمية التى يتم بها فترة التثريب. 
11 - 11

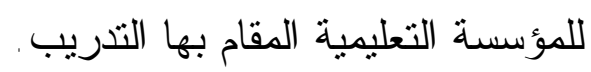
r ا -التقويم الدورى لأداء الطلاب المعلمين باستخدام النماذج الخاصة بذللك. rا إعداد تقارير الثقييم النهائية الخاصة بالطلاب المعلمين ومنحهم الدرجات المستحقه. مسؤليات ومهام المشرف الجامعى تجاه المشرف المدرسي: 1 -مناقثة فلسفة واهداف التدريب الميدانى مع المشرف المدرسي. r -مناقثة منطلبات الكلية من خلال التثريب مع الطالب المعلم مثل (ساعات التثريب، الثقويم وتقارير الملاحظة،الانشطة الأخرى التى يقوم بها الطالب المعلم داخل المدرسة). ب -تزويد المشرف المدرسي بمعلومات كافيه حول الطالب المعلم حيث يعد المشرف الجامعى المصدر الأساسي للمعلومات. ع -توضيح دور المشرف المدرسي كمشرف داخلى تجاه للطالب المعلم المتدرب. ه -توضيح دور الكلية فى التدريب الميدانى ومدى الدعم الذى قد تقدمة للمدرسة. 1 -تقديم المشورة للمشرف المدرسي حول أحداث و أفضل الممارسات التعليمية فى مجال تخصصة. V r rعمل كحلقة وصل بين الطالب المعلم و المعلم المدرسي(المشرف الداخلى). مسؤليات ومهام المشرف المدرسي (المشرف الداخلى): ا بوضح نظام العمل المتبع فى الغرفة الصفية للطالب المعلم. ب بزود الطالب المعلم بالمو ادو الوسئل التعليمية الت يحتاج إليها فى عمله. r بـزود الطالب المعلم بنماذج العمل التى يحتاج إليها من خطط وتقارير . ع - بحدد الجدول الدر اسى الخاص بالطالب المعلم. ه بساعد الطالب المعلم فى عملية تقييم المتعلمين. 1 - بتيح للطالب المعلم فرصة الحوار و المناقثة معه. V - ميوفر للطالب المعلم بيئة تعليمية تساعدة على تعليم المتعلمين بشكل فعال.

\section{مجلة علوم وفنون الموسيقى - ملية التربية الموسيقية - المجلد الاثنين والأربعون - يناير •r.r}


1 -يقدم للطالب المعلم التغذية الر اجعة حول تخطيط الدروس بوقت كاف. 9 -يقوم بملاحظة الطالب المعلم أثناء إعطاء الدرس. • ا -يقام التغذية الر اجعة المناسبة للطالب المعلم بعد الإنتهاء من إعطاء الدرس. 1 ا يتعاون مع مشرف الجامعة لتحديد ما حققة الطالب المعلم من أهداف البرنامج التدريبي. r ا يقوم بتقييم الطالب المعلم بشكل مستمر ويطلعة ويطلع مشرف الجامعة على نتائج التقييم. rا بتعامل مع الطالب المعلم بكل إحتر ام وتقدير . ع ا - يساعد الطالب المعلم على حل المشكلات التى تو اجهه أثناء التثريب الميدانى. 10 -يعزز الإتجاهات الإيجابية للطالب المعلم نحو مهنة التعليم. 17 - يلم بأهداف التّريب الميدانى ويحرص على تحقيقها مع الطالب المعلم. V ا يوضح أهمية التدريب الميدانى للطالب المعلم لمرحلة ما بعد التخرج من الجامعة. 11 - الثقويم الدورى لأداء الطلبة المعلمين باستخدام النماذج الخاصة بذللك. 9 1 -إعداد تقارير التقييم النهائية الخاصة بالطلبه ومنحهم الدرجات المستحقه. مسؤليات ومهام مدير المؤسسة التعليمية (المدرسة): 1 تعريف الطالب المعلم بالنظام و اللو ائح التعليمية المتبع داخل المدرسة. r - Tعاملة الطالب المعلم بصورة حسنه. r -الإهتمام بملاحظات الطالب المعلم و الإستجابة لها. ع تتعريف الطالب المعلم بمر افق ومكونات المدرسة. ه -اثر اك الطالب المعلم بالنشاطات اللاصفية التى تقام فى المدرسة. 1 - متابعة الإجر اءات الإداريه المتعلقة بالطالب المعلم (الحضور و الغياب). V -الإلمام بأهداف التنريب الميدانى و العمل على تحقيقها مع الطالب المعلم. ^ -الثقويم الدورى لأداء الطلبة المعلمين باستخدام النماذج الخاصة بذلك. 
9 - إعداد نقارير التقييم النهائية الخاصة بالطلبه ومنحه الدرجات المستحقه(يحي عبيدات، محمد

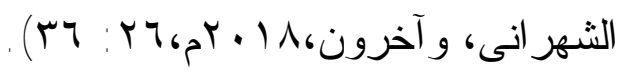

$$
\begin{aligned}
& \text { مفهوم الميثاق الأخلاقي: }
\end{aligned}
$$

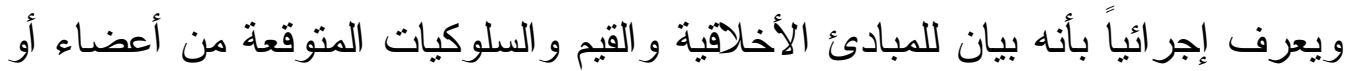

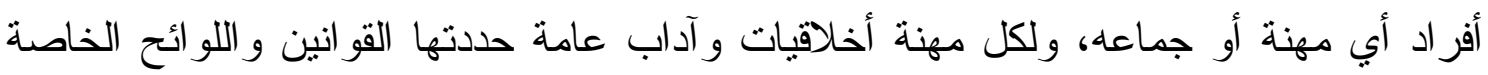

$$
\text { الميثاق الأخلاقي للتدريب الميداني: }
$$

من خلال المساعي الهامة داخل الوطن و النهوض به يجب الاهتمام بالتنريب الميداني حتى

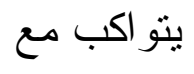

خطة التتمية المستدامة للمجتمع، حيث أن تكوين المعلم اختيارًا و إعدادًا وتدريبًا لا يكفي، بل لا

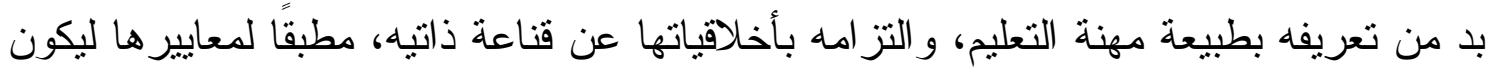

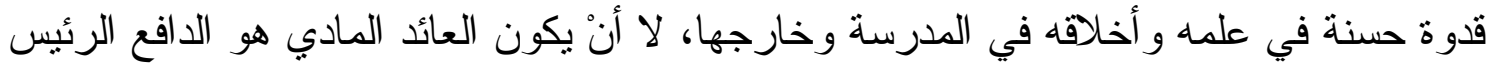

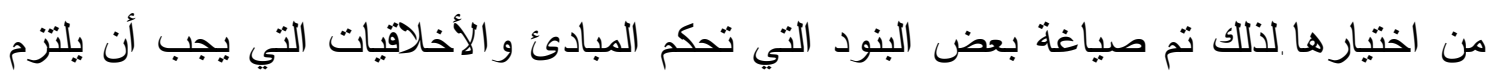

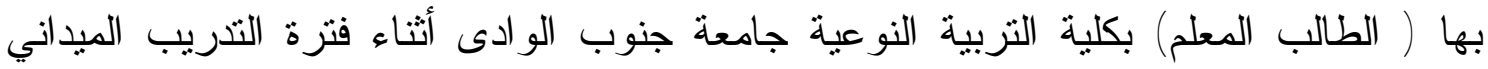
و التي أطلقنا عليه الميثاق الأخلافي للتدريب الميداني و يتمنك في الاتي: أولاً: المظهر الخارجي: - أن -إلتز ام الطالب المعلم بالزي الذي يتتاسب مع أخلاقيات المهنة. - الالتز ام بالتصرفات الملائمة له كمعلم(حركات، صوت، وغير ها ....).

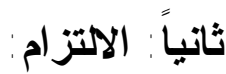

$$
\text { -الالتز ام بحضور طابور الصباح المدرسي. }
$$

-حضور الحصة الدراسية في الموعد المخصص لها. -الالتز ام بقانون وضو ابط ونظام المدرسة المتبع.

\section{مجلة علوم وفنون الموسيقى - ملية التربية الموسيقية - المجلد الاثنين والأربعون - يناير •r.r}


ثالثاً: الاتصال و التواصل: - م

كيجب على الطالب المعلم استخدام لغة حوار سليمة ومهذبة سواء مع المتعلمين أو مع المعلمين داخل المدرسة أو مع إدارة المدرسة المتمثلة في مدير المدرسة ووكيل المدرسة. - التعامل مع الطلاب بشكل لائق. -التو اصل الإيجابي بين إدارة المدرسة و المشرفين.

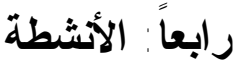

يجب على الطالب المعلم المشاركة في الأنشطة المدرسية(اللاصفية) منل : الإذاعة المدرسية، المسرح الغنائي أو الأنثطة التي تتم داخل البيئة الصفية. -إعادة تدوير الوسائل التعليمية المستخدمة في تجميل المدرسة.

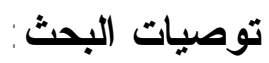

من خلال نتائج البحث يمكن تقديم مجموعة من التوصيات وهى كالتالى:

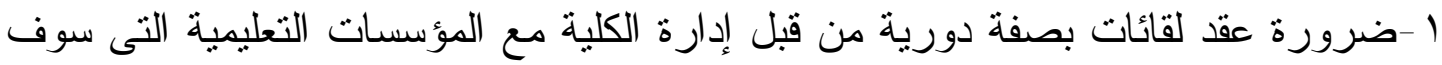

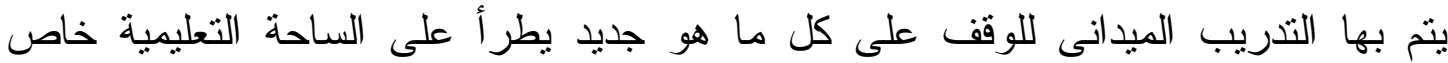

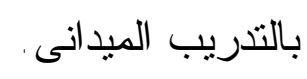
r -تطبيق نظام متابعة جيد للطالب المعلم حتى يتحقق الهذف من التدريب الميدانى. r- -ضرورة تقديم التقارير بصفة مستمرة من قبل المشرف المدرسي والإدارة المدرسية

$$
\begin{aligned}
& \text { للجهات المسئوله عن التدريب الميدانى. } \\
& \text { البحوث المقترحة: }
\end{aligned}
$$

ا -طريقة مقترحة تعتمد علي استر اتيجية التعلم النشط لتتمية التفكير الابداعى للطالب المعلم أثناء

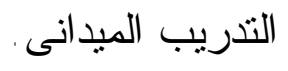

$$
\text { r - كر اسة تتبعية لكثف الفروق الفردية بين الطلاب في التذريب الميداني. }
$$

r -أثز استخدام استراتيجية تدريس الفريق لرفع مستوى أداء الطالب المعلم أثناء التدريب الميدانى. 
ابر اهيم بسيوني(997 (م) ) تدريس العلوم والتربية العملية، القاهرة، دار المعارف. انشر اح إير اهيم محمد المشرفى( . . rم). فاعلية برنامج مقترح لتتمية كفايات تعليم التفكير الإبداعى لدى الطالبات المعلمات بكلية رياض الأطفال، رسالة دكتوراه، كلية

$$
\text { التربية، جامعة الإسكندرية. }
$$

أميمة عبد الحميد ابر اهيم( ... بم) . تقييم مادة تقييم التربية الميدانية لطلبة الدر اسات العليا بقسم

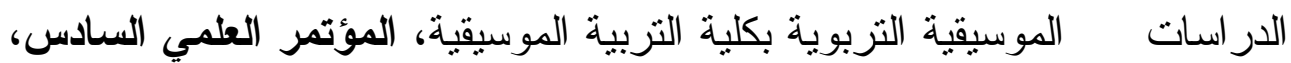

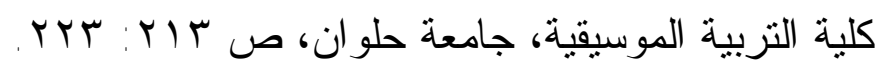

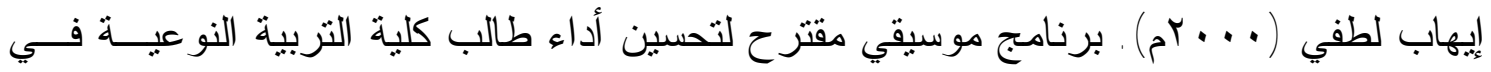
التربية الميدانية، رسالة ماجستير، كلية النربية الموسيقية، جامعة حلو ان.

بدرية حسن على حسن(10 • rم) ببرنامج مقترح فى الثزبية الموسيقية لتتمية بعض كفايات

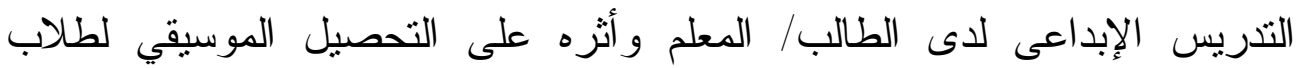

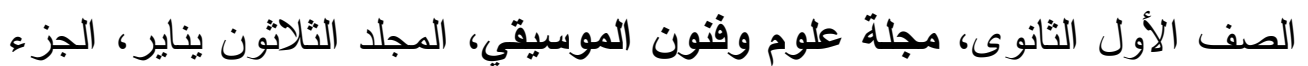

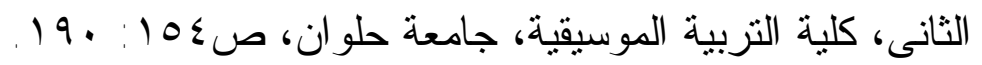
رانيا مصطفي عبدالقادر (T . . rم). تنليل بعض الأخطاء الثائعة و الصعوبات الني تواجه

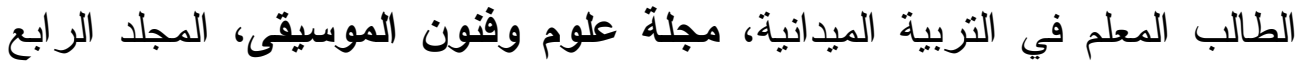
عشر ، كلية التربية الموسيقية، جامعة حلوان، 1101) على المبروك عون عبد الجليل(rا • rم). أسس التدريب العملى فى مجالات الخدمة الإجتماعية، القاهرة، بورصة الكتب للنشر و التوزيع.

محمد ناصر عجيل العجيل(1 . بام). تقويم أداء معلم التربية الفنية فى المرحلة الابتدائية فى ضوء الكفايات التدريسية، رسالة ماجستير، كلية التزبية الفنية، جامعة حلوان. محمد رضا البغدادي،هيام محد البغدادي(• ( •rم).التنريس المصغر و التربية العملية،القاهرة،

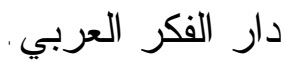


مددوح جابر شلبى، ابر اهيم جابر، و آخرون(1 ( ـ זم). تقنيات التعلم وتطبيقاتها فى المناهج،

$$
\text { مجد خضر (ج ا ـ rم) . أساليب التعليم/التدريب الميدانى. دار العلوم والإيمان للنشر و التوزيع. }
$$

متاح على موقع: https://mawdoo.com

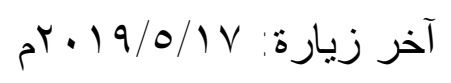

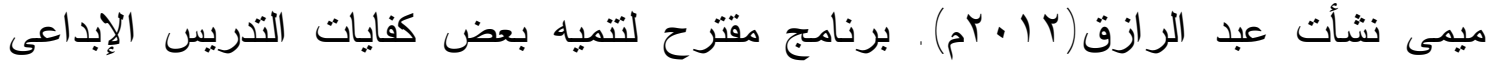

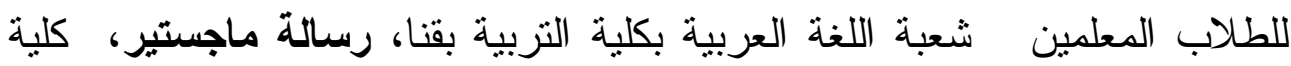

$$
\text { التزبية بقنا، جامعه جنوب الو ادي. }
$$

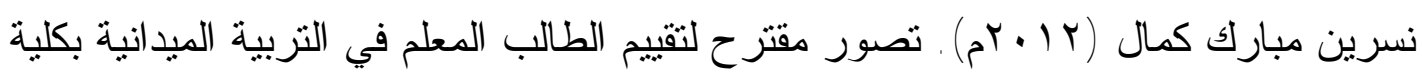
التزبية النوعية بقنا، مجلة علوم وفنون الموسيقي، يونيو الجزء الأول، كلية

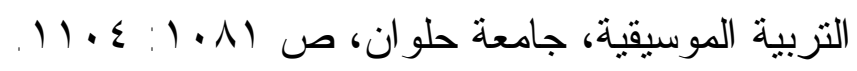

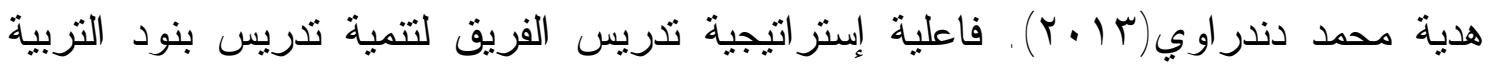

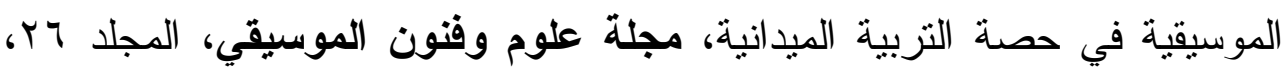

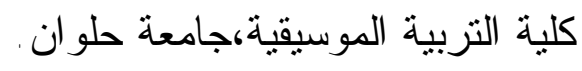

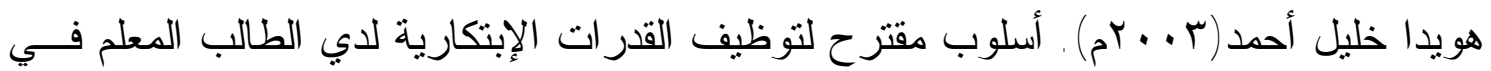

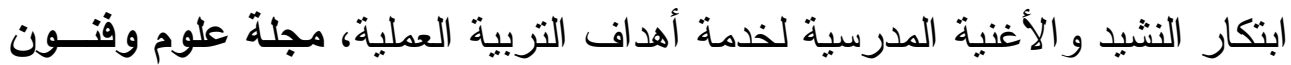

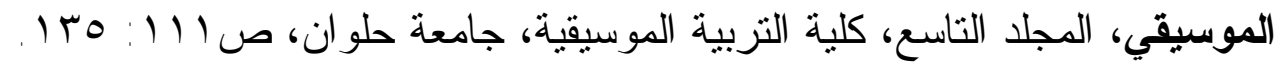
يحي عبيدات، محمد الثهرانى، أحمد الدوايدة، وآخرون(1) • (Y). دليل التدريب الميدانى فى التربية الخاصة، جدة، المملكة العربية السعودية، دار اليازوري العلمية للنشر ولئرون

$$
\text { و التوزيع. }
$$

وليد الحيالى(10 بم) .التتريب فى المؤسسات التعليمية استراتيجيات تحديثها وتفعيلها. https://books.google.com.eg متاح على موقع:

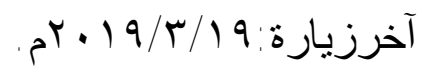

\section{مجلة علوم وفنون الموسيقى - ملية التربية الموسيقية - المجلد الاثنين والأربعون - يناير •r.r}


قائمة المراجع الإجليزية: - مان

Burnard, Parnela. (2012). Rethinking Creative Teaching and Teaching as Research: Mapping the Critical Phases that mark Times of change and choosing as Learners and Teachers of muaic, Theory Into Practice , v51 n3 p167-168.

Franziska Vogt, Marion Rogalla (2009). Developing Adaptive Teaching Competency Through coaching, Teaching and Teacher Education, Volume 25,Issue8, November.

Jeffrey, B.(2006).creative teaching and Learning: Towards a common Discourse send Practice, Cambridge Journal of Education, sep,(3) 399-414. 


\section{ملخص البحث}

دراسة تتبعيه للتدريب الميدانى بين الواقع والمأمول في ظل الجودة والاعتماد

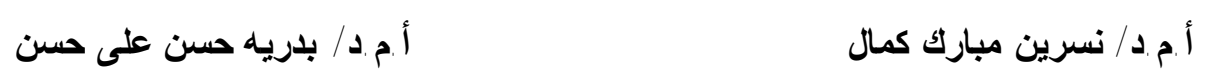

هدف البحث الحالى إلى التعرف على و اقع مستوي أداء طلاب الفرقة الثالثة و الر ابعــة

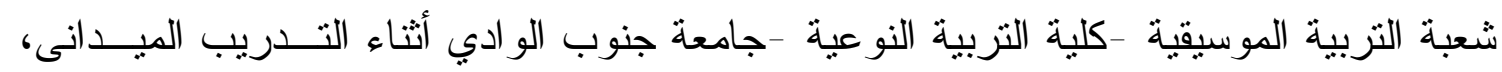

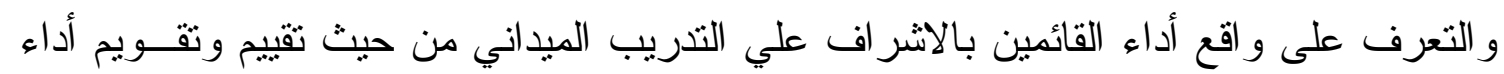
الطلاب وترجمته إلي درجات، التعرف على الأدلة و الثو اهد المطلوبه لـعيار التنريس و الــتـعلم طبقاً لمنطلبات الجودة في التدريب الميدانى.

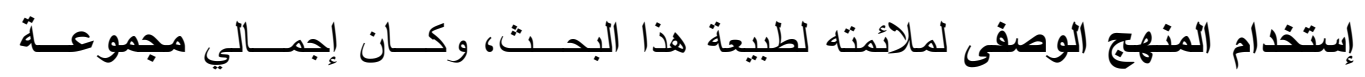

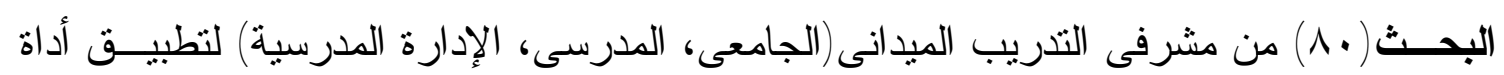

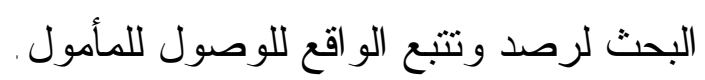

وكاتت أهم النتائج التي توصل إليها البحث الحالى بعد الإجابة عن اسئته: يــتم تقيـــيم

الطالب المعلم أثناء التنريب الميدانى بشكل اجتهادى دون استخدام مقاييس محددة، تحديد قائهـــة

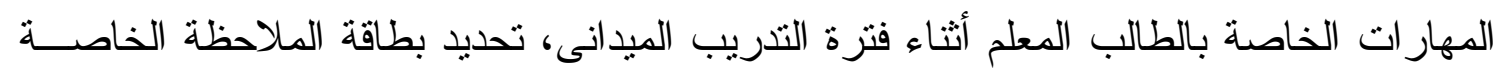

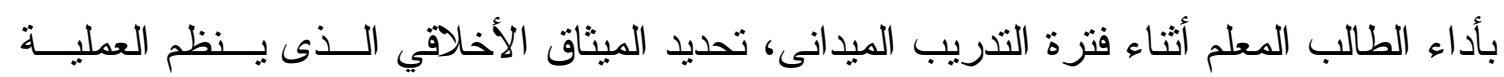
التعليمية أثناء فترة التنريب الميدانى.

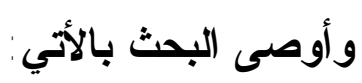

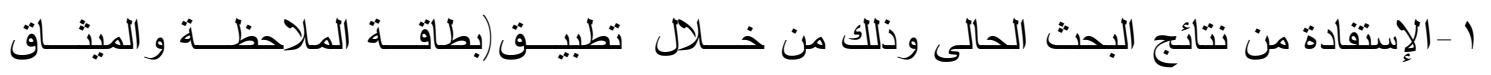

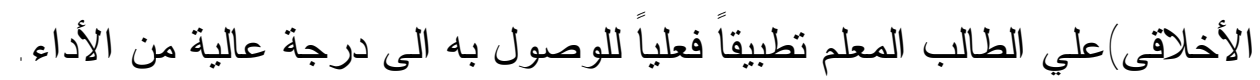
ب -المتابعة الدورية و الإهتمام بالتدريب الميداني بإعتباره أساس الدراســـة بالكليـات النوعيــة و التزبوية. r -الحرص علي استخدام معايير و أسس ثابتة ومقننه لكتابعة التدريب الميداني. ـ -الإهتمام بالفروق الفردية و أهميتها في خلق روح المنافسة التي ترفع وتحسن مــن مسستوي

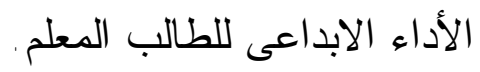

\section{مجلة علوم وفنون الموسيقى - ملية التربية الموسيقية - المجلد الاثنيز والأربعون - يناير •r.r}




$$
\text { وحدد البحث بعض البحوث المقترحة وهى كالتالى: }
$$

ا -طريقة مقترحة تعتمد علي استر اتيجية التعلم النشط لتتمية التفكير الابداعى للطالب المعلم أثناء

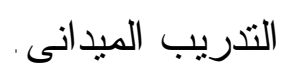

$$
\text { r -در اسة تتبعية لكثف الفروق الفردية بين الطلاب في التشريب الميداني. }
$$

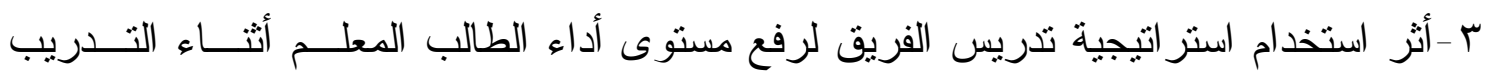
الميدانى. 


\section{Summary}

\section{Tracking study for Field Training between Reality and Perspective In the Light of Quality and Accreditation}

\section{Prof. Dr. Nisreen Mubarak Kamal}

Prof. Dr. Badria Hassan Ali Hassan

The aim of the current research is to identify real performance level of 3rd and 4th year students in Music Education Division - Faculty of Specific Education - South Valley University during field training, to identify the real performance of field training supervisors in terms of improving and evaluating students' performance and translating it into degrees, and to identify the required clues and evidences for teaching and learning standard in accordance with quality requirements in field training.Descriptive approach usage as the appropriate to this research nature, and the total of the research group was (80) from field training supervisors (university, school, and school administration) to implement the research tool to monitor and follow up reality to reach the prospective.

The most important results of the current research after answering its questions were: undertraining teacher is evaluated during the field training without using specific measurements, and specifying the list of skills for the undertraining teacher during the field training period, and determining undertraining teacher performance observation card during the field training period, and defining the ethical code of conduct that organizes the educational process during the field training period.

\section{The research recommended the following:}

1- Use the current research results through the actual application of (note card and ethics code of conduct) on the undertraining teacher to reach with him to a high degree of performance.

2- Periodical follow-up and attention to field training, as it is the studying base in the Specific Education colleges and the Educational ones.

3- Keen the use of basic and certified standards to follow-up the field training.

4-Concern with the individual differentiations and its importance in creating a spirit of competition that raises and improves the level of creativity of the undertraining teacher. 
The research identified some of the proposed researches as follows:

1- A suggested method depends on an active learning strategy to develop the creative thinking of the undertraining teacher during field training.

2- A follow-up study to discover individual differences among the students in field training.

3- The effect of using Team teaching strategy to raise performance level of undertraining teacher during field training.

مجلة علوم وفنون الموسيقى -كلية التربية الموسيقية - المجلد الاثنيز والأربعون - يناير •r.r. 